\title{
GOTIČKA UMJETNOST U PRIMORJU, GORSKOJ ŽUPI I RADOBILJI U VREMENU HERCEGA STJEPANA VUKČIĆA KOSAČE - IZMEĐU STVARNOSTI I PREDAJE
}

\author{
Marinko TOMASOVIĆ \\ Gradski muzej Makarska \\ Obala kralja Tomislava 17/1 \\ 21300 Makarska \\ E-pošta: marinko.tomasovicl@gmail.com
}

\author{
UDK: 7.033.5(497.5):929.7 Kosača S. V. \\ 726.033.5(497.5):929.7 Kosača \\ Izvorni znanstveni rad \\ Primljeno: 31. siječnja 2017 \\ Prihvaćeno: 5. travnja 2017
}

Sažetak

Pregledno se i uz kritičke napomene donosi prikaz i povijesne okolnosti pojave likovne umjetnosti na prostoru današnjega Makarskog primorja, donjeg toka lijeve strane Cetine, Zabiokovlja i donjoneretvanskoga pojasa u 15. st., kojom se prezentira gotički stil. Osim arhitekture crkava, skulpture i slikarstva, obuhvaćene su i utvrde, u prvom redu naznakom njihove uloge u razdoblju vladavine hercega Stjepana Vukčića Kosače. Istaknute su i one gradnje koje za hercega Stjepana vezuje predaja, te su kao takve i toponimijski posvjedočene.

Ključne riječi: gotička arhitektura crkava; liturgijsko posuđe; reljefni križevi; oslikani križevi; bilizi (stećci); nadgrobne ploče; učelci; križine; utvrde; Hercegova kula; Ercegova gradina. 
Likovna umjetnost u 15. st. u Primorju (Krajini), Gorskoj župi i Radobilji, omeđenim donjim tokom Cetine i Neretve, bila je u osobitom razvoju kada je ovim krajevima, oko 1440.-1466., vladao bosanski vojvoda Stjepan Vukčić Kosača, gospodar Huma. Sačuvani ostatci umjetnosti nose oznake zreloga gotičkog stila, zacijelo već definiranoga u vremenu vladavine hercega Stjepana sredinom stoljeća. Iako pisani izvori ne potvrđuju najizravnije, time i pouzdano, gradnje crkava i opremanje njihovih unutrašnjosti, kao i druge likovne aktivnosti, upravo u vrijeme njegove vlasti nad ovim prostorom, gotovo i nema sumnje kako je njihov veći, ili barem dobar dio, nastao upravo tijekom toga vremena. Pregled spomenika gotičke umjetnosti, osobito u kontekstu prvih navoda crkava u izvorima, potvrda su za takvo zauzimanje. Pak, upravo spomenici koji izravno svjedoče vlast hercega Stjepana, a to su brojne utvrde, u izvorima često navedene kao ključna uporišta u njegovu posjedu, pružaju i najmanje podataka o izgledu sredinom 15. st. Zbog čestih pregradnji, danas i njihova ruševnog stanja, najmanje ocrtavaju sliku "gotičkih" utvrda. Neovisno, predaja je pojedine gradnje vezala za ime Stjepana Vukčića Kosaču, čime je uz preostale spomenike na ovome prostoru uistinu naznačeno, o čemu će biti govora, vrijeme gotike u 15. st. kao razdoblja i njegove dugotrajne vladavine. ${ }^{1}$

\section{Crkve - arhitektura}

Sačuvane crkve između donjih tokova Cetine i Neretve, te brojni lokaliteti i položaji, upućuju i na kasnoantičke i srednjovjekovne ostatke. Njima se pridodaju još uvijek dvojbene gradnje, ali izgledne u arheološkom kontekstu prostora, hagiotoponimije i toponomastičkih indicija. ${ }^{2}$ Osobito na obali istaknut je i sloj crkava koji u povijesnom i spomeničkom kontekstu nesumnjivo pripada gotičkom razdoblju

1 Političke okvire hercegove vlasti u Primorju (Krajini), osobito u odnosu s dubrovačkom vladom, naznačio je: Vinko Foretić, "O vezama starog Dubrovnika i Makarskog primorja", u: JAKšA RAVlić (prir.), Makarski zbornik, I., Znanstveno savjetovanje o Makarskoj i Makarskom primorju, 28.-30. rujna 1969., Makarska, 1970., str. 184-194.

2 Marinko Tomasović, "Toponomastika i hagiotoponomastika kroz arheološke indicije za obalni pojas između donjeg toka Cetine i Neretve", u: TomisLaV ŠEPAROvić (prir.), Dani Stjepana Gunjače. Hrvatska srednjovjekovna povijesno arheološka baština. Međunarodne teme, 2, Zbornik radova znanstvenoga skupa 18.-21. listopada 2011., Muzej hrvatskih arheoloških spomenika Split, Split, 2012., str. 115-147, gdje je sabrana i literatura. 
od druge polovice 14. st., iako su iznimne gradnje koje arhitekturom govore o intaktnom stilskom izrazu. Mahom je riječ o pregrađenim, barokiziranim crkvama, čiji spomen u izvorima osmanskoga vremena 16.-17. st. gotovo i dokazuje ranije podizanje. Dvostoljetna osmanska vlast u ovim krajevima, od druge polovice 15. do kraja 17. st., uz povremene ratove, razaranja i pljačke, kojima se pridodaje i nemogućnost bržih obnova nakon razornih potresa i požara, umnogome su ovom velikom prostoru brisale izvorni gotički stil, na sjevernijem i južnijem uzmorju, ali i otocima, dostatno sačuvan u arhitekturi crkava, i uređenju njezinih ponutrica. Uz to, u Primorju se kudikamo bolje sagledava arhitektura predromaničkih i romaničkih crkava 11./12. do 13./14. st., neovisno je li ova sačuvana u cijelosti ili temeljima, nego sloj koji je slijedio. Stoga od 28 crkava u današnjem Makarskom primorju, kojima je spomen u izvorima osmanskoga vremena pronašao zaslužni franjevac Karlo Jurišić, izuzetkom četiri (jedne ranoromaničke, dvije pregrađene ili produžene romaničko-gotičke, te jedne najvjerojatnije gotičke) izvorna gradnja nije sačuvana u cijelosti. ${ }^{3}$ Isto vrijedi i za 5 crkava u neretvanskoj krajini. Tek su arheološka istraživanja potvrdila gotički izgled pojedinih crkava, nužno prezentiran u tlocrtnim dispozicijama. Stoga se o njihovoj arhitekturi iz 14.-15. st. ponajprije govori kroz sintagmu barokiziranih gotičkih crkava u 17.-18. st. kada prestaje vlast Osmanlija na ovom području. Vjerojatno su njihove pravokutne apside kakve poznajemo, uz približnu veličinu i prostorne omjere, donekle nalik izvornim gradnjama. Osim spomena u izvorima osmanskoga vremena na pripadnost crkava 14.-15. st. upućuju i nadgrobni spomenici uokolo njih. ${ }^{4}$ Izlišno je ponovo opisivati sve crkve pretpostavljene kao gotičke, ali valja podsjetiti na dvije, nekada nesumnjivo reprezentativne u očitovanju gotičkoga stila. Riječ je o franjevačkim crkvama posvećenih Gospi, u Zaostrogu i Makarskoj, od kojih je potonja, unatoč pregradnjama nakon rušenja u 16. i 17. st. do nas dospjela u, gotovo se može sa sigurnošću reći, nebitno izmijenjenim arhitektonskim omjerima. Obje su morale predstavljati i stilski uzor manjim gradnjama 15. st. u Primorju, osobito u izgledu pravokutnih apsida. Makarska franjevačka crkva tlocrtom $s$ jednim brodom i pravokutnom apsidom odražava karakterističan izgled propovjedničkih gradnji, iako od toga pone-

3 KARlo JuRišić, "Crkve biokovsko-neretvanskog područja u doba turske vladavine", u: Kačić, II., Split, 1969., str. 101-154.

4 Marinko Tomasović, Srednjovjekovni nadgrobni spomenici u Makarskom primorju, Gradski muzej Makarska, Makarska, 2007. 
T.
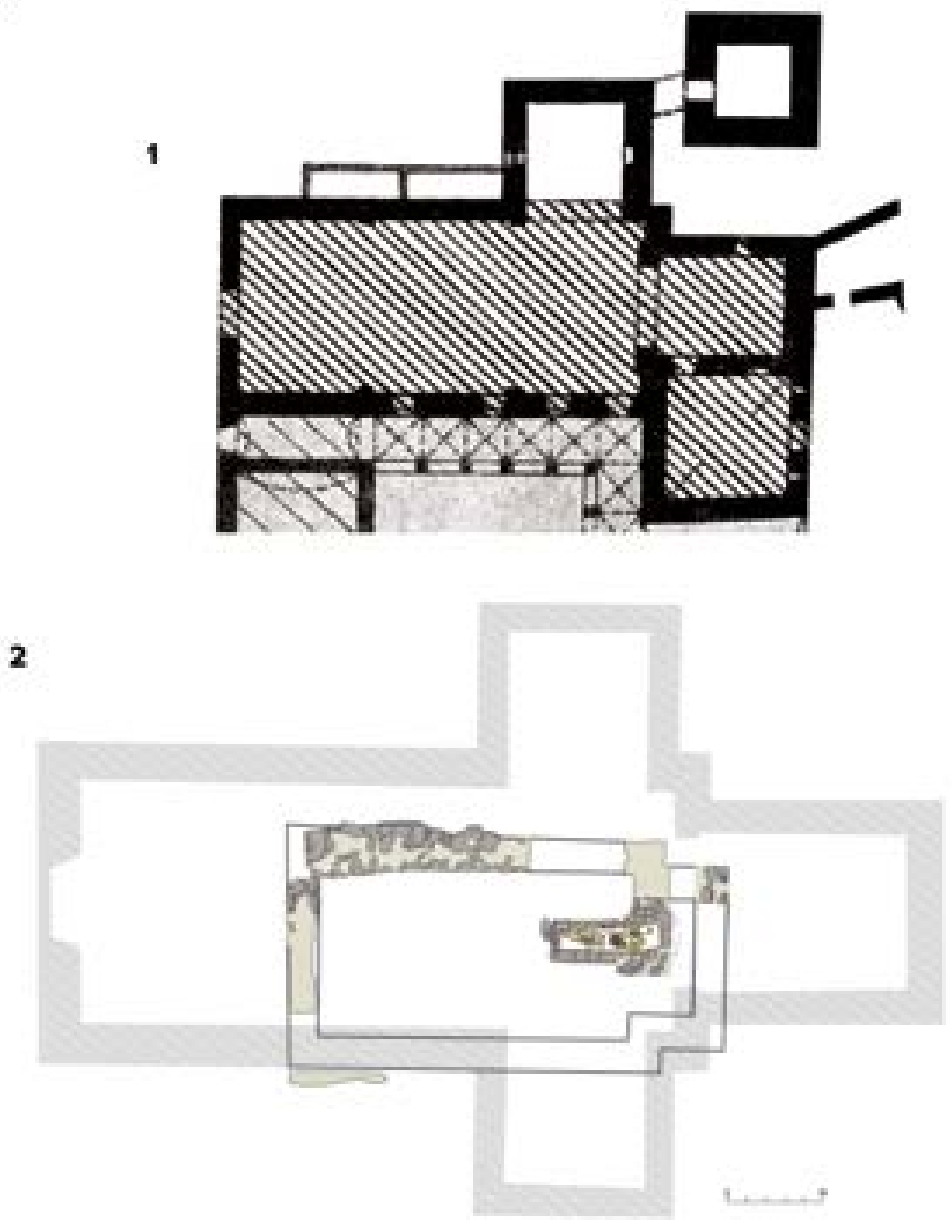

3

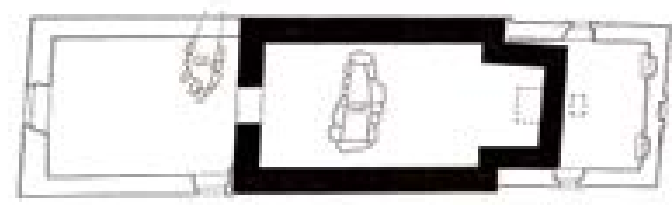

ton $+1,1$

Tlocrti gotičkih crkava:

1. Franjevačka crkva sv. Marije u Makarskoj (prema A. Badurina, 1984.)

2. Sv. Luka u Kučićima (prema M. Tomasović, 2016.)

3. Sv. Nikola u Borovcima (prema M. Tomasović, 2001.) 
što odudara prelomljenim svodom u lađi, svakako postavljenim još u izvornoj gradnji (T., 1). ${ }^{5}$ Podignuta je u 15 . st. jer se već 1502 . navodi kao trošna. ${ }^{6}$ Neovisno je li građena od franjevaca ili preuzeta, ${ }^{7}$ obnovom od temelja do 1523., upravo je uvjetom osmanske vlasti i zadržala raniji izgled. Podizanjem se vezuje za vrijeme do 1468., a potom "barem oko" 1438. zaslugom vladara Primorja Jurjevića-Vlatkovića, prilikom čega se u oba slučaja govori o preuzimanju crkve od strane franjevaca, a ne njihovoj gradnji. ${ }^{8}$ Potonja se mogućnost i dopustila, iako u domišljanju kako se franjevci tek vraćaju na svoj položaj. ${ }^{9}$

Odlaskom augustinaca iz Zaostroga 1468. crkvu i titular Sv. Mariju, izravno spomenutu 1494., preuzimaju franjevci. ${ }^{10}$ Dok je makarska

5 O najranijem nadsvođivanju makarske franjevačke crkve doznajemo iz pisma bosanskog provincijala fra Antuna Matkovića, koji se 1573. žali mletačkom duždu zbog rušenja samostana od strane njegovih podanika. Istom prilikom naglašava kako je to bio povod da Osmanlije poruše crkvu, za koju ističe da je bila nadsvođena: K. JuRIŠIć, "Crkve biokovsko-neretvanskog područja u doba turske vladavine", str. 148. Prelomljeni svod ima i franjevačka crkva u Slanom, dovršena 1461.: ANĐELKo BADURINA, Uloga franjevačkih samostana u urbanizaciji dubrovačkog područja, Institut za povijest umjetnosti - Kršćanska sadašnjost, Zagreb, 1990., str. 88-89. Ovim obje crkve donekle odudaraju od uvriježene predodžbe o crkvama propovjedničkih redova čije lađe imaju otvorena krovišta ili drvenu tavanicu (tabulatum).

6 K. JuRIŠić, "Crkve biokovsko-neretvanskog područja u doba turske vladavine", str. 109.

7 Razmatranja o boravku benediktinaca i augustinaca na mjestu Franjevačkoga samostana u Makarskoj vidi: M. Tomasović, "Toponomastika i hagiotoponomastika kroz arheološke indicije za obalni pojas između donjeg toka Cetine i Neretve", str. 128, 133-135, bilj. 265.

8 K. JuRIŠIĆ, "Crkve biokovsko-neretvanskog područja u doba turske vladavine", str. 109; KARLO JURIŠIĆ, Katolička crkva na biokovsko-neretvanskom području u doba turske vladavine, Analecta croatica christiana, Kršćanska sadašnjost, Zagreb, 1972., str. 13, 92.

9 K. JURIŠIć, Katolička crkva na biokovsko-neretvanskom području u doba turske vladavine, str. 93.

10 K. JuRIŠIĆ, "Crkve biokovsko-neretvanskog područja u doba turske vladavine", str. 121; K. JuRIšić, Katolička crkva na biokovsko-neretvanskom području u doba turske vladavine, str. 13. Za augustinski samostan u Zaostrogu, Primorju ili Krajini, u blizini kojega je 1460. opljačkan korčulanski trgovac vidi: Mladen Ančić, Na rubu Zapada. Tri stoljeća srednjovjekovne Bosne, Dom i svijet/Hrvatski institut za povijest, Zagreb, 2001., str. 268. 
Gospina crkva u općim crtama zadržala rani izgled, zaostroška je izmijenjena u 18.-19. st. ${ }^{11}$

Pak, Sv. Nikola u Gornjim Brelima, na zapadnom izdanku Biokova, vjerojatno je i jedina izvorno sačuvana manja gotička crkva u Primorju, iako se neizravno spominje tek $1597 .{ }^{12}$ Unatoč tomu što je izgubila obrise i gotičku profilaciju otvora, jednobrodnim tlocrtom $\mathrm{s}$ pravokutnom apsidom i nadasve bez istaknutih baroknih intervencija na tijelu i u ponutrici, usamljena je u predodžbi o "klasičnom" izgledu jednostavne crkve iz 14.-15. st. na priobalju (slika 1).

Tip jednobrodnih crkava s pravokutnom apsidom javlja se u 14. st. i posve je karakterističan za 15. st. i stilsku pripadnost zrelom go-

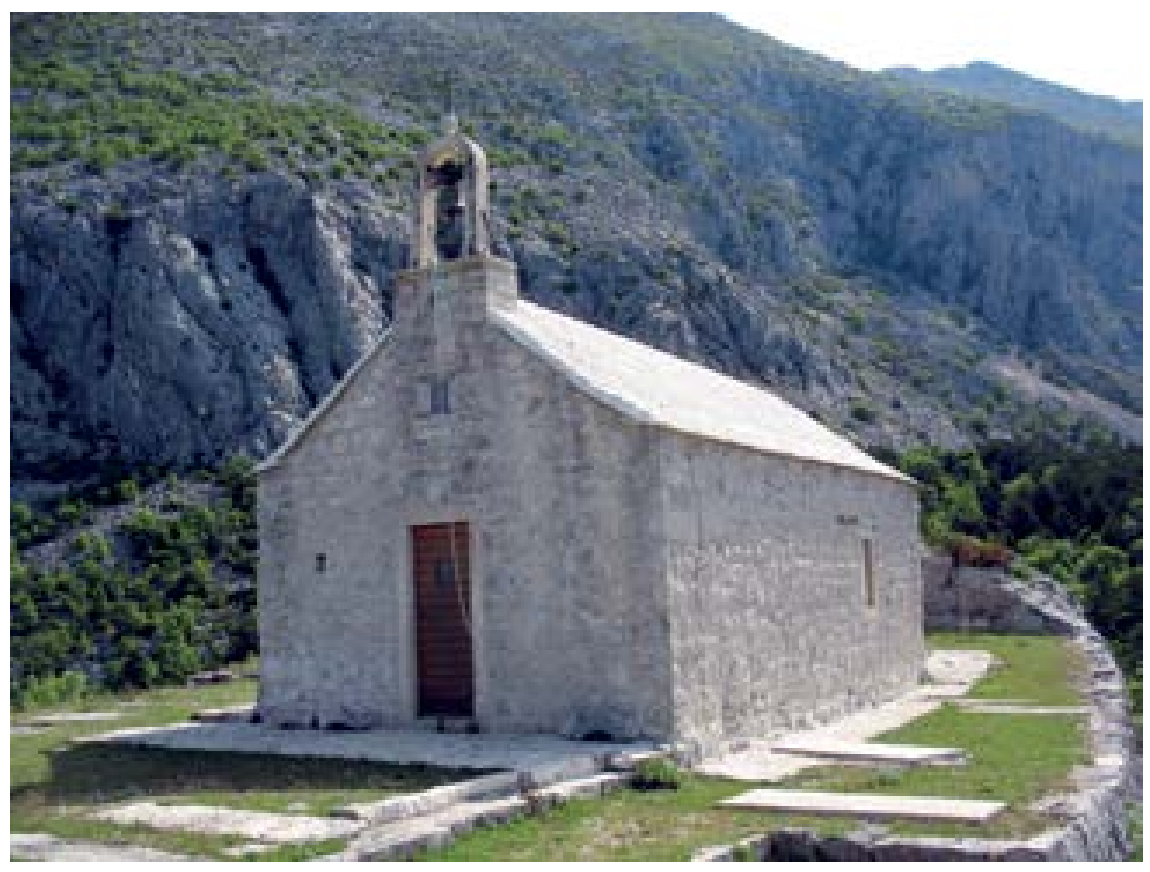

Sl. 1. Crkva sv. Nikole u Gornjim Brelima (foto: Marinko Tomasović)

11 AnĐelko Badurina, "Samostanska arhitektura podbiokovskog područja Franjevačke provincije presv. Otkupitelja", u: Kačić, XVI., Split, 1984., str. 236-249.

12 K. JURIŠIĆ, "Crkve biokovsko-neretvanskog područja u doba turske vladavine", str. 104. 
tičkom graditeljstvu kasnoga srednjeg vijeka. ${ }^{13}$ Iznimni su primjeri koji se datiraju u prvu polovicu 14 . st., ${ }^{14}$ dok se većina izostankom pisanih izvora vremenski ne može pouzdano odrediti. ${ }^{15}$ Crkva sv. Kuzme i Damjana u nedalekoj Lokvi Rogoznici nema sačuvanu apsidu, čime je otvoreno pitanje izvornoga izgleda (slika 2). Ipak, na

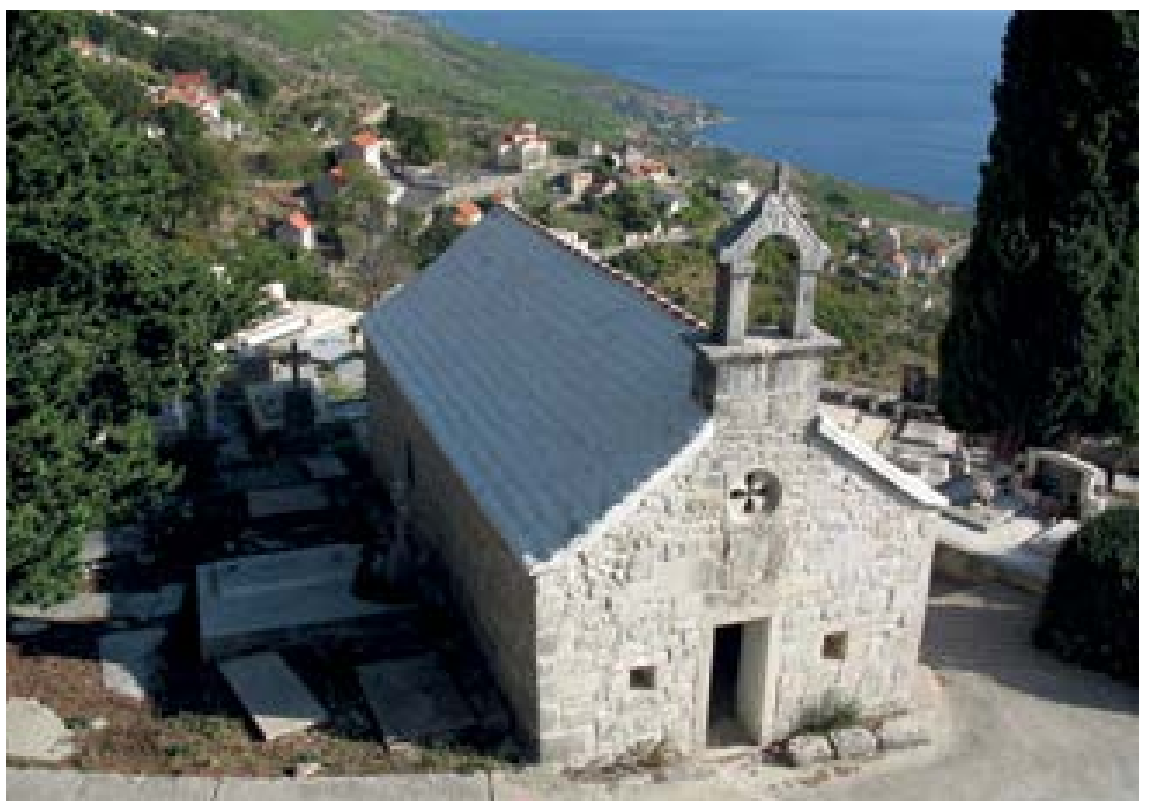

Sl. 2. Crkva sv. Kuzme i Damjana u Lokvi Rogoznici (foto: Marinko Tomasović)

13 Pregled takvih priobalnih crkvica vidi u: Marinko Tomasović, Srednjovjekovna crkva Sv. Nikole i groblje na Zanogi u Borovcima, Crkva u svijetu, Split, 2001., str. 16-32. Nadopunjuju se davno otkrivenim na gornjocetinskom području, datiranih u kasni srednji vijek: Ante MiLošEvić, Arheološka topografija Cetine, Muzej hrvatskih arheoloških spomenika, Split, 1998. str. 98-100, sl. 161; str. 108, sl. 175; str. 134-135, sl. 221.

14 Za dvije takve crkvice: EMıL HiLje, "Kasnosrednjovjekovna sakralna arhitektura na Pagu", u: Diadora, 18-19, Zadar, 1997., str. 427-431.

15 Uz to, čitav je niz seoskih crkvica na obali i u zaleđu, čiji je spomen posvjedočen u osmanskom razdoblju, izgubio izvorni oblik. Za južnije krajeve, gdje je i tvrdokornije zadržavanje romaničkoga stila, vidi: MARINKo ToMASOvić, "Crkvena arhitektura Huma - od kasnoantičke tradicije do srednjovjekovnih načela (Neka problemska sagledavanja gradnji u srednjem vijeku)", u: IviCA Lučıć (prir.), Hum i Hercegovina kroz povijest, I., Zbornik radova s međunarodnoga znanstvenog skupa u Mostaru 5.-6. studenoga 2009., Hrvatski institut za povijest, Zagreb, 2011., str. 173-187. 
njezinu kasnosrednjovjekovnu gradnju, osim spomena $1461 .,{ }^{16}$ upućuju i nadgrobne ploče uokolo. ${ }^{17}$ Obje gotičke gradnje, breljansku i rogozničku, povezuje i crkva sv. Luke u nedalekim Kučićima s lijeve strane donjeg toka rijeke Cetine. Selo se u pisanim izvorima spominje prvi put još 1237., ${ }^{18}$ a potom i u ispravi kneza Jurja II. Šubića 1315. navodom stanovništva (Cuchani), zajedno sa Svinišćanima (Yfnien/ ses/), Rogozničanima (Rogosnien/ses) i Breljanima (Brolanenses). ${ }^{19}$ Arheološkim istraživanjima 2016. otkriveni su njezini temelji pod većom baroknom crkvom. Ocrtavaju jednobrodnu crkvu s plićom pravokutnom apsidom, čija je veličina u odnosu na današnju osjetno manja (T., 2). ${ }^{20}$ Datirana je od druge polovice 14 . do sredine 15. st., svakako prije dolaska Osmanlija, što je vremenski uklopljivo i u razdoblje vladavine Kosača u omiškom zaleđu. Na ovom prostoru tada gotovo sigurno postoje i druge gotičke crkve. Zajedno s kučićkim Sv. Lukom, Gospinom u Svinišćima (navedenom kao kučićkom!), Gospinom i crkvom sv. Kuzme i Damjana u Rogoznici, kao i preostalim poljičkim crkvama, navedene su 1625 . u popisu Ivana Tomka Mrnavića, suradnika papinskoga pohoditelja dalmatinskih biskupija Oktavijana Garzadorija, i crkve sv. Ivana Krstitelja u Slimenu, Gospina i Gospina rođenja u Radobilji, te Gospina crkva u Podgrađu. ${ }^{21}$ Nesumnjivo su sve podignute prije osmanske vlasti na ovom poljičko-radobiljskom prostoru, jer je teško povjerovati kako bi u nemilosti njihove dugotrajne vladavine uopće bilo moguće podizati toliko brojne

16 Mile Vidović, Splitsko-makarska nadbiskupija, Župe i ustanove, Crkva u svijetu, Split, 2004., str. 378.

17 Marinko Tomasović, "Kasnosrednjovjekovne nadgrobne ploče starog omiškog i rogozničkog groblja", u: Omiški ljetopis (Župa sv. Mihovila arkanđela u Omišu), V/5, Omiš, 2009., str. 98-101.

18 Slavko Kovačić, "Najstariji je poznati spomen sela Kučića u dokumentu od 23. lipnja 1237.", u: Zov rodnih ognjišta, List župe Sv. Luke - Kučiće, XI./1(20), Kučiće, 2005., str. 12-15.

19 Diplomatički zbornik Kraljevine Hrvatske, Dalmacije i Slavonije (ur. T. Smičiklas), VIII., listine g. 1301.-1320., Zagreb, 1910., str. 394.

20 Marinko Tomasović, "Arheološka istraživanja u Kučićima: otkriće temelja crkve Sv. Luke iz 14.-15. st.", u: Zov rodnih ognjišta, XXII./2(43), Kučiće, 2016., str. 15-28.

21 Slavko Kovačić, "Župe splitske nadbiskupije u Poljičko-radobiljskom dekanatu g. 1625.", u: MARIJAN STEINER (ur.), Synthesis theologica, Zbornik u čast p. Rudolfa Brajčića S. J. prigodom 75. obljetnice života, Zagreb, 1994., str. 646. 
crkve. ${ }^{22}$ Srednjovjekovno postanje crkava iz Mrnavićeva popisa 1625. dokazivale bi i one rogozničke, osim Sv. Kuzme i Damjana spomenutog 1461., i crkva Uznesenja B. D. Marije, na mjestu današnje iz druge polovice 19. st., spomenuta u izvoru 1495. kao S. Dominiçe de rosogniça, ${ }^{23}$ te potom $1527 .{ }^{24}$

Rjeđi spomeni crkava u zabiokovsko-vrgoračkom prostoru, nekadašnjoj Gorskoj župi, u vrijeme osmanske vladavine također upućuju na gotičke gradnje. Crkva Gospina Rođenja u vrgoračkoj Vlaci spomenuta je u vizitaciji 1636., ${ }^{25}$ a Sv. Petra u Dusini $1585 .{ }^{26}$

Crkvi sv. Nikole u Borovcima s desne strane Neretve, nedaleko od srednjovjekovne utvrde Vratar, konzervatorska i arheološka istraživanja 2000. dokazala su stariji sloj. Otkriveni temelji pravokutne apside (T., 3), uza sačuvane dijelove južnog zida crkve (slika 3), datiraju

22 Poneki izuzetci govore o kompleksnim okolnostima podizanja crkava u zabiokovskom Zagvozdu i Rašćanima u vrijeme osmanske vlasti: K. JURIšIć, "Crkve biokovsko-neretvanskog područja u doba turske vladavine", str. 133140. Zapis o gradnjama crkava u župi Vrdol na prijelazu 16. u 17. st., Sv. Ivana u Župi Biokovskoj i Sv. Mihovila u Rašćanima, govori i o položajima Orašje, Postinje i pod Kljenom kod Sv. Mihovila, na kojima se u nedostatku crkava slavila Misa na otvorenom: SLAv ko Kovačıć, "Iz povijesti rašćanske župe Sv. Mihovila arkanđela", u: Rašćane - Sv. Mihovil 1600.-2000. g., Rašćane, 2000., str. 10. Tumačenje ovih položaja kao vjerojatnih mjesta s crkvom i u predosmansko vrijeme, u pogledu biliga (stećaka) u blizini, ali i općeg slavljenja Misa na grobljima u to vrijeme, razumljivo je po sebi. O nedoumicama kod ubikacija spomenutih toponima u Župi Biokovskoj i susjednim Rašćanima vidi: M. Tomasović, "Toponomastika i hagiotoponomastika kroz arheološke indicije za obalni pojas između donjeg toka Cetine i Neretve", str. 136.

23 Lovre Katıć, "Popis župa iz XV. vijeka u okolici Splita", u: List Biskupije splitsko-makarske, LX., 3-5, Split, 1938., str. 52, gdje se prevodi kao Sv. Nediljica.

24 Stavko Kovačić, "Nadžupska crkva sv. Mihovila u Omišu", u: Omiški ljetopis, 2, Omiš, 2002., str. 12.

25 Slavko Kovačić, Najstariji izvještaji o stanju Makarske biskupije u Tajnom vatikanskom arhivu, Nadbiskupijski arhiv Split, Split, 1975., str. 41. Vjerojatno se radi o položaju današnje crkve $B$. D. Marije u Zavojanima s kontinuitetom od kasnog srednjeg vijeka, očitim u pogledu ugrađenih biliga (stećaka): M. Tomasović, "Toponomastika i hagiotoponomastika kroz arheološke indicije za obalni pojas između donjeg toka Cetine i Neretve", str. 123.

26 M. Tomasović, "Toponomastika i hagiotoponomastika kroz arheološke indicije za obalni pojas između donjeg toka Cetine i Neretve", str. 125, s navodima iz literature. 


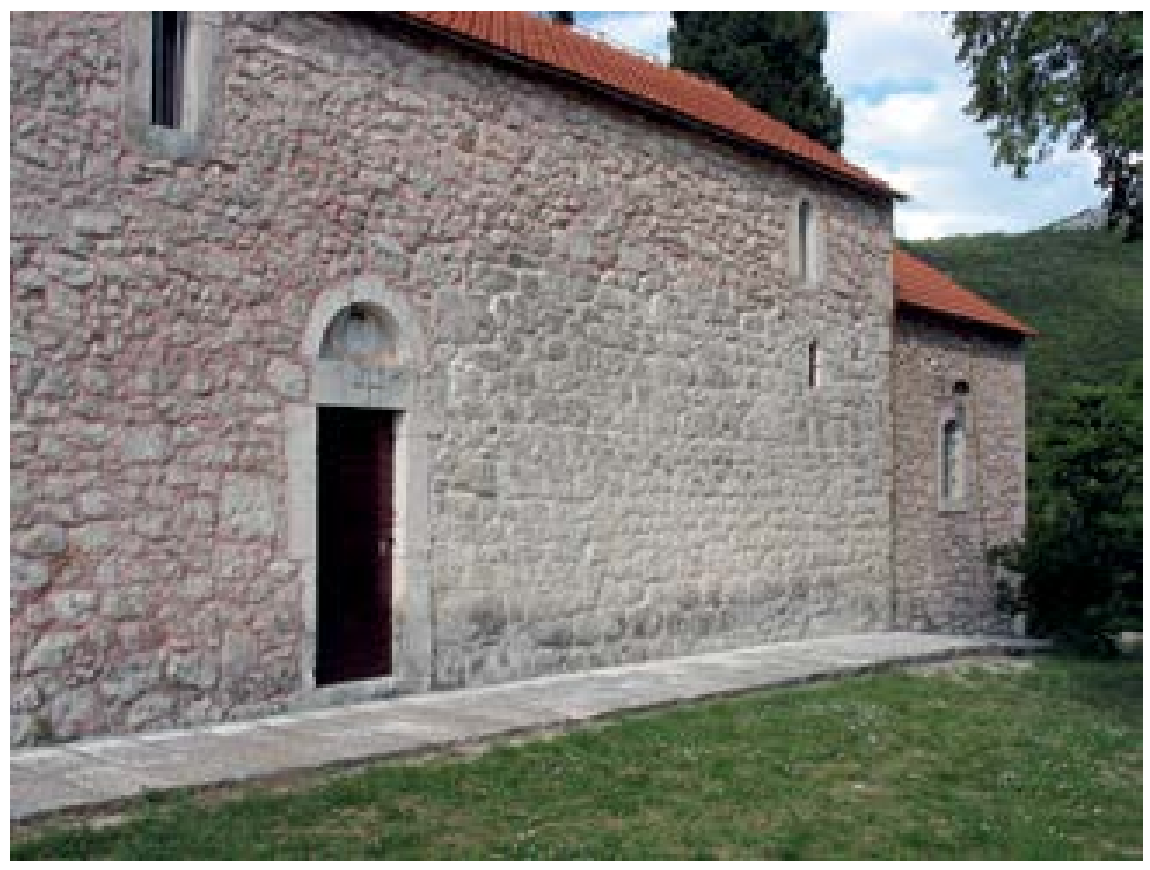

S1. 3. Izvorni dio južnog zida gotičke crkve sv. Nikole u Borovcima (foto: Marinko Tomasović)

je od kraja 14. do 15. st., ${ }^{27}$ čime postaje prethodnicom u očekivanju brojnijega arhitektonskog gotičkog sloja i na donjoneretvanskom prostoru. ${ }^{28}$ On se zasigurno očitovao i na crkvama sv. Marije i sv. Vida spomenutih u Neretvi-Gabeli tijekom 14. i 15. st., ${ }^{29}$ a još je vidljiv u prelomljenom svodu crkve sv. Ivana na otočiću Osinju, iako joj polukružna apsida prije govori kako je podignuta u prijelaznom romaničko-gotičkom slogu, puno ranije od njezina spomena $1629 .{ }^{30}$

27 M. Tomasović, Srednjovjekovna crkva Sv. Nikole i groblje na Zanogi u Borovcima, str. 16-33.

28 Za srednjovjekovnu crkvenu arhitekturu u slivu Neretve vidi: M. TomAsović, "Crkvena arhitektura Huma - od kasnoantičke tradicije do srednjovjekovnih načela (Neka problemska sagledavanja gradnji u srednjem vijeku)", str. 179-184.

29 Marijan Sivrić, "Srednjovjekovna humska župa Luka", u: Emilio Marin (prir.), Arheološka istraživanja u Naroni i dolini Neretve, Izdanje Hrvatskog arheološkog društva, 22, Zagreb - Metković - Split, 2003., str. 386.

30 K. JURIŠIĆ, "Crkve biokovsko-neretvanskog područja u doba turske vladavine", str. 127. 


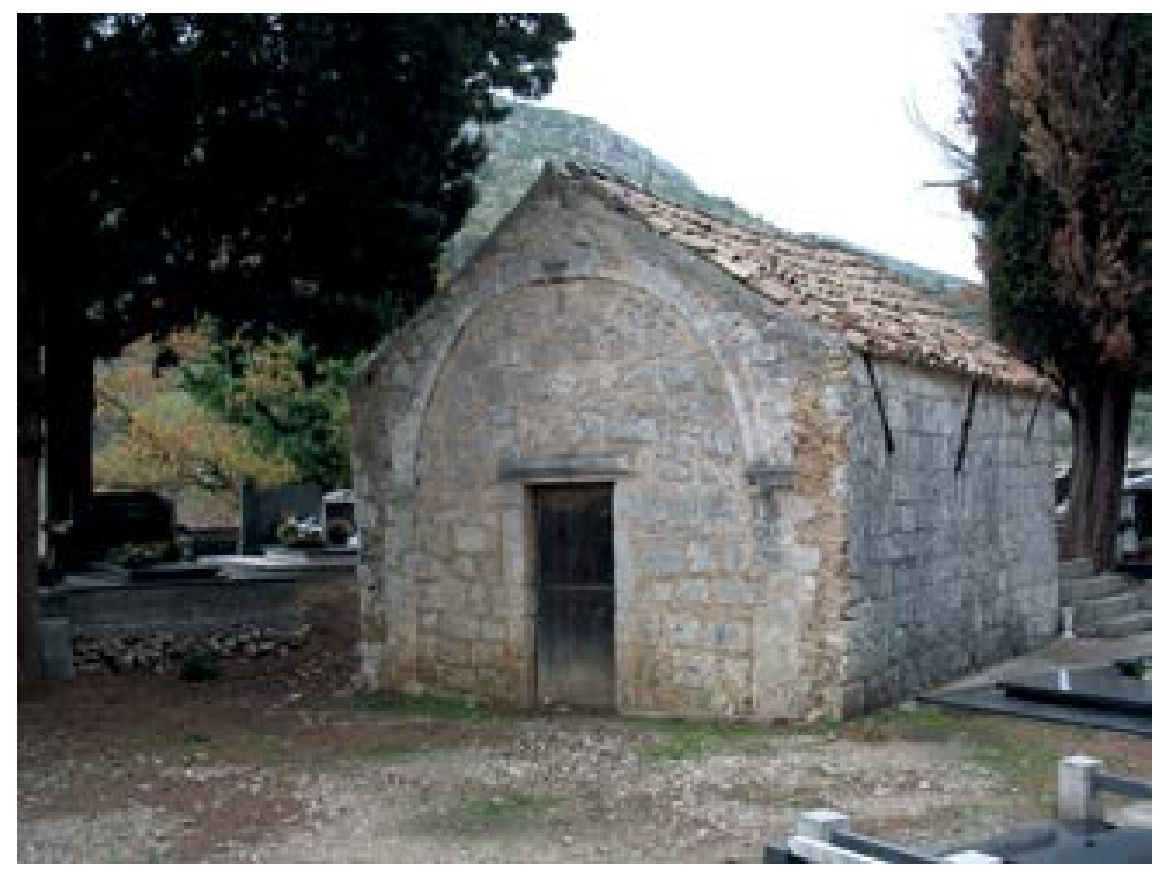

S1. 4. Pravokutna apsida crkve sv. Stjepana u Slivnu Ravnom preuređena u grobljansku kapelu (foto: Marinko Tomasović)

Gotička je nesumnjivo crkva sv. Stjepana u Slivnu Ravnom, od koje je preostala pravokutna apsida preuređena u grobljansku kapelu (slika 4). ${ }^{31}$ Izgledne su i brojnije gotičke crkve u donjoneretvanskom kraju, možda tek pregrađene u vrijeme od kraja 14. st., jer se njihove nasljednice podižu gotovo redovito na kasnosrednjovjekovnim grobljima ili se, pak, očituju toponimijski i predajom u kontekstu kasnosrednjovjekovnih lokaliteta. ${ }^{32}$

Možda je crkva sagrađena i u sklopu grada-utvrde Brštanik, kojega je 1383. podigao kralj Tvrtko I. uz lijevu stranu Neretve, a koji od osnutka i nosi naziv Sv. Mihovila (...salemdifferent ad forum sub

31 Spominje je 1624. fra Blaž Gračanin i 1629. biskup Andrijašević: RAdovaN Jerković, "Povijest neretvanskih župa", u: Mile Vidović (prir.), Don Rade Jerković, život i djelo, Matica hrvatska, Metković, 2000., str. 444.

32 Marinko Tomasović, "Donjoneretvanska (hagio)toponimija u prilog crkvenih gradnji od kasne antike do kasnoga srednjeg vijeka", u: Hrvatski neretvanski zbornik, 8, Društvo Neretvana i prijatelja Neretve u Zagrebu, Zagreb, 2016., str. 126-131. 


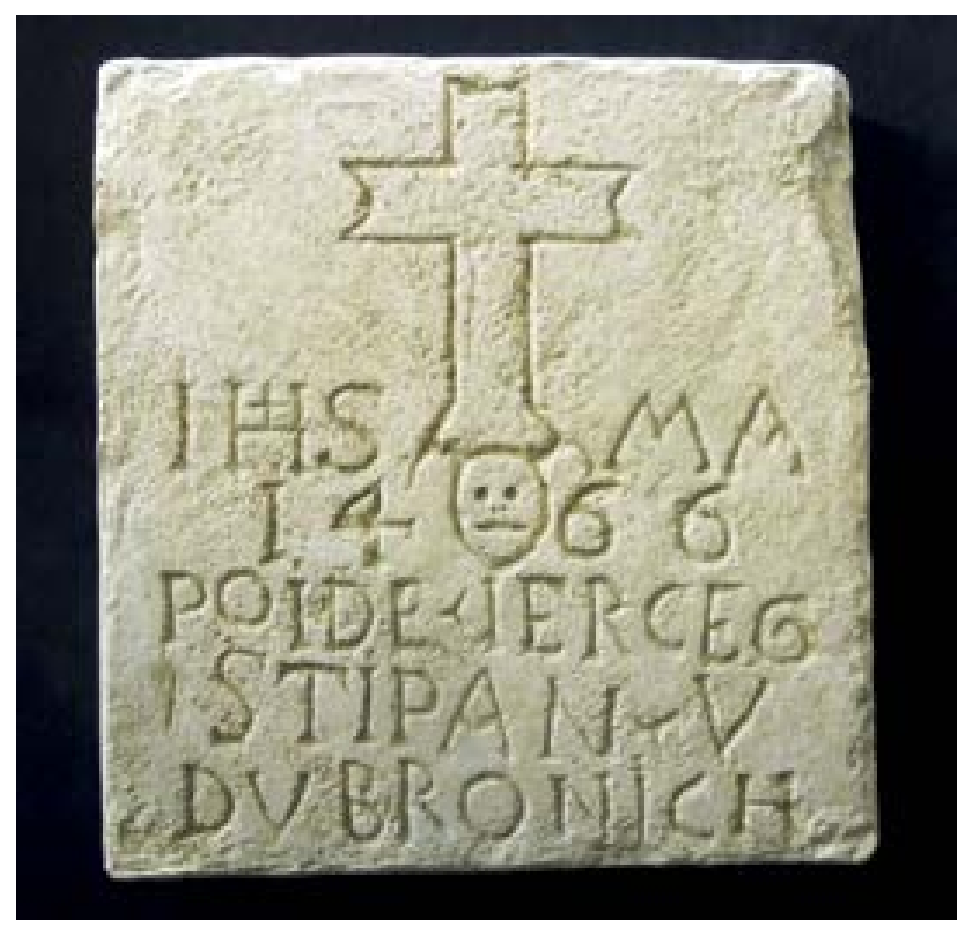

S1. 5. Natpis iz Drašnica sa spomenom hercega Stjepana Kosače (foto: Marinko Tomasović)

castro Brostanik Sancti Michaeli sappellatum....). ${ }^{33}$ Na njezino postojanje, osim hagionima, upućivalo bi i podizanje crkvice sv. Nikole u omiškoj tvrđavi Starigrad, iako se ova navodi tek 1603. i u funkciji je do kraja 18. st. ${ }^{34}$ Obje tvrđave aktivne su i u vrijeme hercega Stjepana Kosače, u čijem su kratkotrajnom posjedu i bile.

Navedenim crkvama, više ili manje posvjedočenim ili pretpostavljenim gotičkim gradnjama od druge polovice 14 . do polovice 15 . st., osobito treba pridodati Sv. Stjepana na Koledniku uza Stojno polje u primorskim Drašnicama. Njezina važnost istaknuta je u pogledu natpisa (vel. 29,5 x $28 \times 8 \mathrm{~cm}$; slika 5) sa spomenom hercega Stjepana Kosače i 1466. godinom (HIS + MA / 1466 / POIDE.IERCEG / STI-

33 Đuro Tošıć, "Brštanik u srednjem vijeku (ćirilica)", u: Godišnjak Društva istoričara Bosne i Hercegovine, XXI.-XXVII., Sarajevo, 1976., str. 40, bilj. 19.

34 Slavko Kovačić, "Crkvena prošlost Omiša i okolice", u: Žarko Domljan (prir.), Omiš i Poljica, Zagreb, 2006., str. 189. 
PAN. V / DVBROVNIK.), a koja lokalnom predajom potječe s Kolednika. Neovisno o autentičnosti vremena izrade natpisa, za kojega je rečeno da je mogao nastati i početkom 17. st., sadržajem nedvosmisleno potvrđuje, ako ne sami prolazak, onda kakvu diplomatsku ili poduzetnu nakanu hercega Stjepana u Drašnicama. ${ }^{35}$ Po svemu sudeći ona je ostvarena upravo gradnjom crkve, koju je herceg podigao u čast svecu imenjaku. Sami izostanak spomena crkve sv. Stjepana u pisanim izvorima osmanskoga vremena od kraja 15. do 17. st. ujedno govori kako je crkva tada bila ruševna te stoga, poput još nekih srednjovjekovnih u Makarskom primorju (Sv. Martin i Sv. Vid u Tučepima; Sv. Spas i Sv. Mihovil u Igranima; Sv. Andrija u Baćini) i nije mogla biti spomenuta. Do njezine korjenite obnove, u kakvom je izgledu danas (slika 6), očito dolazi krajem 17. ili početkom 18. st., nedugo po

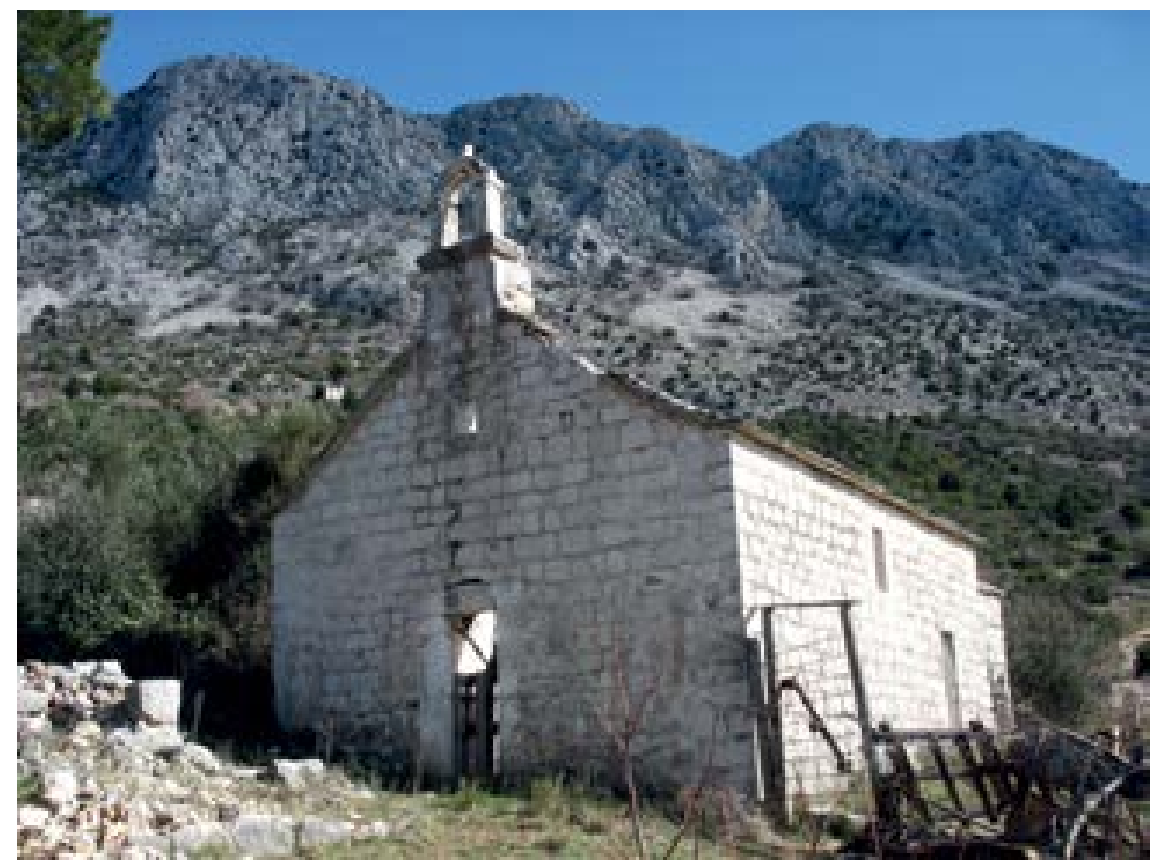

Sl. 6. Crkva sv. Stjepana na Koledniku u Drašnicama nakon temeljite obnove u 18. st. (foto: Marinko Tomasović)

35 O natpisu, danas u Muzeju hrvatskih arheoloških spomenika u Splitu, s ranijim osvrtima vidi: KARLO JURIŠIć, "Stariji hrvatski natpisi Makarskoga primorja (XV-XVIII st.)", u: Starine, JAZU, 53, Zagreb, 1966., str. 119-122. 
prestanku osmanske vlasti u ovim krajevima. ${ }^{36}$ Nema sumnje da je selo Drašnice, u pisanim izvorima prvi put spomenuto $1523 .,{ }^{37}$ imalo značaj i u vrijeme vladavine Stjepana Vukčića Kosače i njegovih nasljednika. Upravo se susjedno Igrane navode u izvorima 1466., koje je herceg Stjepan kao selo poklonio mletačkome časniku, ${ }^{38}$ ali i 1480. kada ga kao svoj posjed u darovnici priznaje kralj Matija Korvin. ${ }^{39}$ Crkvu sv. Stjepana u Drašnicama mogao je temeljito obnoviti i Stjepan Kosača, pri čemu ne treba isključiti ni mogućnost promjene titulara. Vjerojatno bi arheološka istraživanja na Stojnom polju odgovorila na pitanje pripadaju li ulomci predromaničke pleterne skulpture iz 8.-9. st., nedavno nađeni kao spolije u crkvi sv. Stjepana, oltarnoj pregradi ranije crkve na njezinu mjestu ili u neposrednoj blizini. ${ }^{40}$ Pak, izradom ukazuje i na dubrovački radionički krug, što je vezuje i za pleternu skulpturu s ljubuškoga Staroga grada. Na nju me upravo upozorio kolega i prijatelj Radoslav Dodig veliki znalac hercegovačke i uopće južnohrvatske povijesti. ${ }^{41}$ Pleterna skulptura u Drašnicama

36 Marinko Tomasović, "Arheološka topografija priobalnih Drašnica i Igrana do kasnog srednjeg vijeka i razmatranja o kontinuitetu lokaliteta", u: $M a$ karsko primorje, 10, Gradski muzej Makarska, Makarska, 2012., str. 24.

37 Karlo Jurišić, "Nazivi naselja Makarskog primorja (Prvi spomen i značenje)", u: JAKŠA RAvlić (prir.), Makarski zbornik, I., Znanstveno savjetovanje o Makarskoj i Makarskom primorju, 28.-30. rujna 1969., Makarska, 1970., str. 99.

38 K. JuRišić, "Nazivi naselja Makarskog primorja (Prvi spomen i značenje)", str. 99.

39 Ivan Božıć, "Mlečani prema naslednicima hercega Stevana", u: Zbornik Filozofskog fakulteta, VI-2 knj., Beograd, 1962., str. 124, bilj. 53, (ćirilica). Na ovo podsjeća: Ante PAPONJA, "Prostor donje Neretve u vojno-obrambenoj strategiji kralja Matijaša Korvina (1458-1490)", u: Hercegovina, 24, Godišnjak za kulturno i povijesno naslijeđe, Mostar, 2010., str. 68, bilj. 115, iako s netočnom paginacijom kod pozivanja na Božićev rad. S pravom konstatira važnost planinskog prijevoja u Igranima, u biti na granici s Drašnicama.

40 M. Tomasović, "Arheološka topografija priobalnih Drašnica i Igrana do kasnog srednjeg vijeka i razmatranja o kontinuitetu lokaliteta", str. 22-24. Skulptura gotovo dokazuju opstojanje zapadnog, benediktinskog reda na Stojnom polju, zastane li se na teorijskoj razini u dilemi razmatranog pitanja njegove redovničke pripadnosti. O tome: M. Tomasović, "Toponomastika i hagiotoponomastika kroz arheološke indicije za obalni pojas između donjeg toka Cetine i Neretve", str. 135.

41 M. Tomasović, "Crkvena arhitektura Huma - od kasnoantičke tradicije do srednjovjekovnih načela (Neka problemska sagledavanja gradnji u srednjem vijeku)", str. 185, bilj. 116. Radi se o cjelovitom nadvratniku iz Arheološke zbirke Franjevačkoga samostana na Humcu u Ljubuškom (nađen oko 1970.), 
i Ljubuškom još jedan je dokaz istoga geopolitičkoga i kulturnoga kruga u protoku nekoliko stoljeća, a nesumnjivo i zanimljiva asocijativna poveznica s kasnim srednjim vijekom. Naime, Stjepan Vukčić Kosača najvjerojatnije je podigao ili obnovio drašničku crkvu, dok se središnja kula Starog grada u Ljubuškom, koji je bio u njegovu posjedu, zove Herceguša. ${ }^{42}$

\section{Skulptura i slikarstvo}

Dok se o gotičkim crkvama 14.-15. st. u Primorju i zaleđu, Gorskoj župi i Radobilji, glavninom doznaje neizravnim putem, naknadnim spomenom u izvorima osmanskoga vremena 16.-17. st., rjeđe i sačuvanim ili gradnjama predočenim u temeljima, ponajviše izostanak brojnijih djela likovne umjetnosti u njihovim ponutricama ili na pročeljima potvrđuje sliku opće "katastrofe" nakon osmanlijskoga osvajanja ovih krajeva od druge polovice 15 . st., nerijetko i ne manje bezobzirnih, pljačkaških i rušilačkih naleta Mlečana i Uskoka. Od nekada zasigurno brojnije gotičke skulpture i slikarstva, možda i ukrašavanja knjiga minijaturama, zlatarstva i sitne plastike, nakita i uopće drvenih ili metalnih i kovinskih izrađevina umjetničkoga i zanatskoga obrta, misnoga ruha i luksuznih odjevnih predmeta, preostalo je premalo dokaza kojima se može ukazivati na specifičnosti ovoga prostora u likovnim prohtjevima ili ukusu, neovisno radi li se o nabavkama ili lokalnoj izradi umjetnina. O izgledu gotičke umjetnosti može se nagađati - zadržimo se tek na istom prostoru - i samim spomenom slikara i majstora u susjednom donjoneretvanskom kraju, čija su djela, radom ili samim podrijetlom umjetnika i zanatlija, barem posvjedočena u onodobnim pisanim vrelima, iako im ni tim putem nije nadoknadiv nestanak u poharama osmanlijsko-mletačkoga sukobljavanja. ${ }^{43}$ Tek je u dobro utvrđenom i od Osmanlija obranjenom Omišu sačuvano kasnogotičko drveno Raspelo u župnoj crkvi. ${ }^{44}$ Napaćenoga i ekspresivnoga Krista s Raspela, sudeći prema

te cvjetnim motivom istorodnom, manjem ulomku nađenom 2006. Pleterna skulptura nosi karakteristike dubrovačkog radioničkog kruga. Nadvratnik, Ljubuška ploča iz 9.-10. st., uskoro je objavljena u: RADosLAV Dodig, Kulturnopovijesni vodič kroz Bosnu i Hercegovinu, Matica hrvatska, Čitluk, 2010., str. 29.

42 R. Dodig, Kulturno-povijesni vodič kroz Bosnu i Hercegovinu, str. 47.

43 M. Sivrić, nav. dj., str. 387-388.

44 Radoslav Tomić, "Umjetnička baština Omiša", u: Žarko Domljan (prir.), Omiš i Poljica, Zagreb, 2006., str. 243-244. 
boravku 1445.-1475. njegovog tvorca Jurja Petrovića, kanonika i prepozita u Splitu, Omišani su možda nabavili i nedugo nakon mletačkoga preuzimanja grada iz vlasti hercega Stjepana Vukčića Kosače. Moguće da se u kojoj crkvi unutar zidina nalazila drvena Bogorodica s Djetetom, danas u crkvi franjevaca na Skalicama. Ovu skulpturu, također datiranu u 15. st., franjevci su dolaskom u Omiš sredinom 18. st. preuzeli iz crkve Gospe od Karmela, spomenute početkom 17. st., a što je bio i uvjet za dobivanje stare crkve. ${ }^{45}$ Pak, sveukupno je umjetnost gotike u Primorju i zaleđu ponajviše poznata zahvaljujući bezimenim majstorima - kovačima i bilizima (stećcima) koje su izrađivali, a čiji je broj i na ovome prostoru još uvijek dolično prezentiran u sačuvanosti. Vanjskom krugu te umjetnosti, iako u drukčijoj namjeni, pripadaju i rijetka klesarska djela još uvijek sačuvana na crkvama ili u izravnom kontekstu s njima. Dva nadvratnika s reljefnim križevima, dislocirani na groblju u Tučepima (slika 7) i onaj s južnih vrata crkve sv. Nikole u Borovcima (slika 8), dokazi su gotičkih crkava nad čijim su vratima postavljani. ${ }^{46}$ Nadvratnici su datirani upravo gotičkim križevima, iako nerazvedenim i stilski ne posve izrazitim, u vrijeme od kraja 14. do polovice 15. st. Dakako, stoje u vremenskom kontekstu datacija crkava, ali i sagledavanjem niza istovrsno oblikovanih križeva na kasnosrednjovjekovnim nadgrobnim spomenicima u Primorju i zaleđu. Oblikom potvrđuju tipološku dugotrajnost izraslu u dosta širokom kulturnom sloju romaničkoga razdoblja, te i nisu uvijek osjetljivi za datiranje. U pogledu starosti crkve, ali i usporedbom s kasnijim reljefima u njoj, kao gotička opredijeljena je i škropionica iz crkve sv. Luke u Kučićima (slika 9). ${ }^{47}$

45 R. Tomić, "Umjetnička baština Omiša", str. 257, 263.

46 Marinko Tomasović, "Je li srednjovjekovna prethodnica Gospine crkve u Tučepima imala dva identična nadvratnika s reljefnim križevima?", u: $M a-$ karsko primorje, 10, Makarska, 2012., str. 43-50; M. Tomasović, Srednjovjekovna crkva Sv. Nikole i groblje na Zanogi u Borovcima, str. 32-33, sl. 9-10.

47 Marinko Tomasović, "Arheološka istraživanja u Kučićima: otkriće temelja crkve Sv. Luke iz 14.-15. st.", str. 22-23, sl. 13. Sličan oblik neprofilirane škropionice s masivnijim križem opredijeljen je i u romaničko razdoblje: ZDENKo ŽERAViCA, "Križevi kao simbol kršćanstva na srednjovjekovnim kamenim nadgrobnim spomenicima - mramori (tzv. stećci) u Konavlima", u: Ivica Lučić (prir.), Hum i Hercegovina kroz povijest, I., Zbornik radova s međunarodnog znanstvenog skupa u Mostaru 5.-6. studenoga 2009., Hrvatski institut za povijest, Zagreb, 2011., str. 361, sl. 42. 


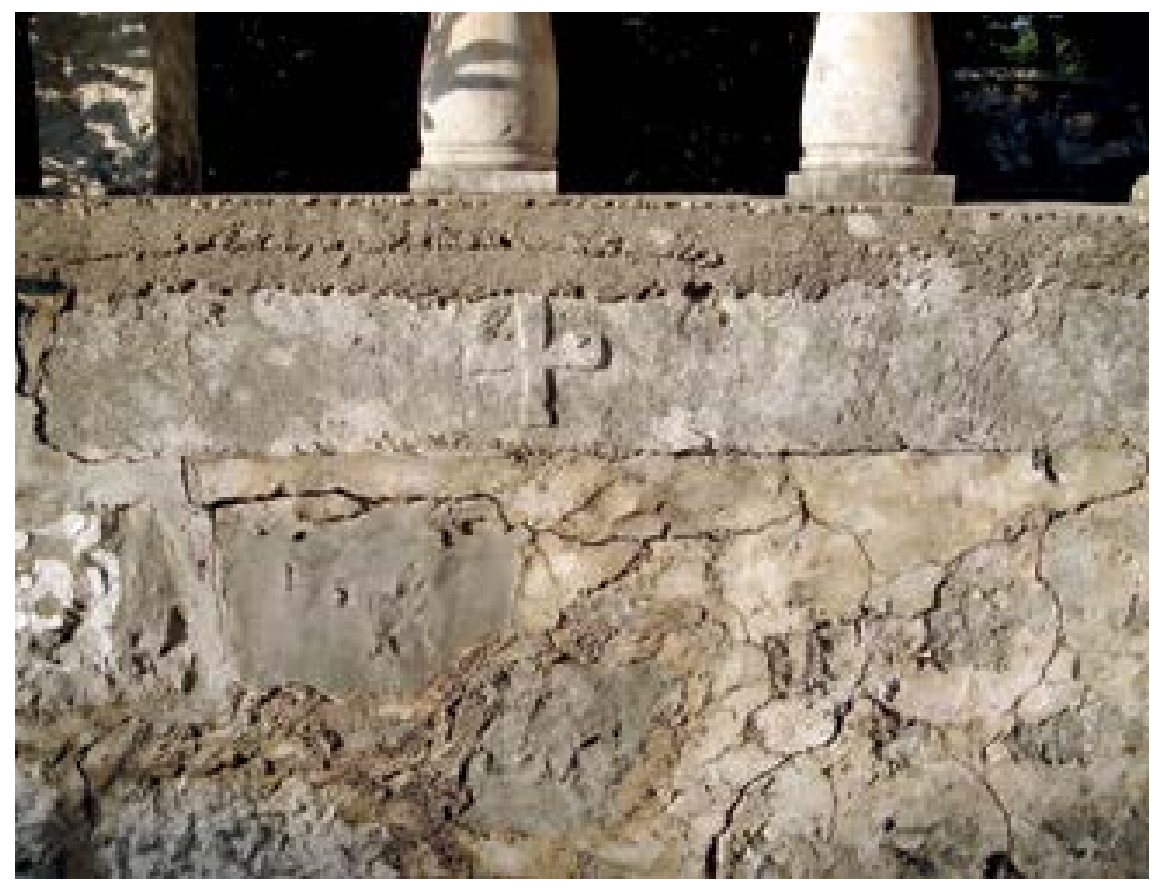

S1. 7. Nadvratnik gotičke crkve na groblju u Tučepima (foto: Marinko Tomasović)

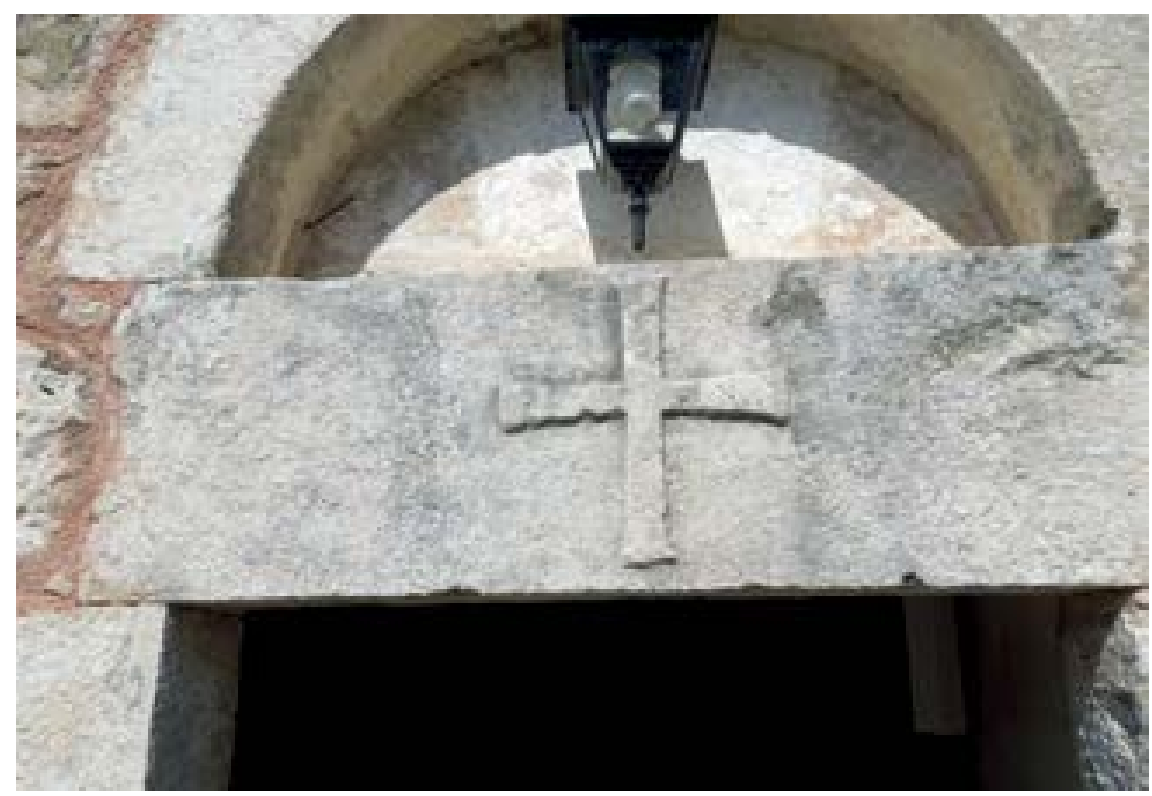

Sl. 8. Nadvratnik južnih vrata crkve sv. Nikole u Borovcima (foto: Marinko Tomasović) 
MARINKO TOMASOVIĆ - GOTIČKA UMJETNOST U PRIMORJU...

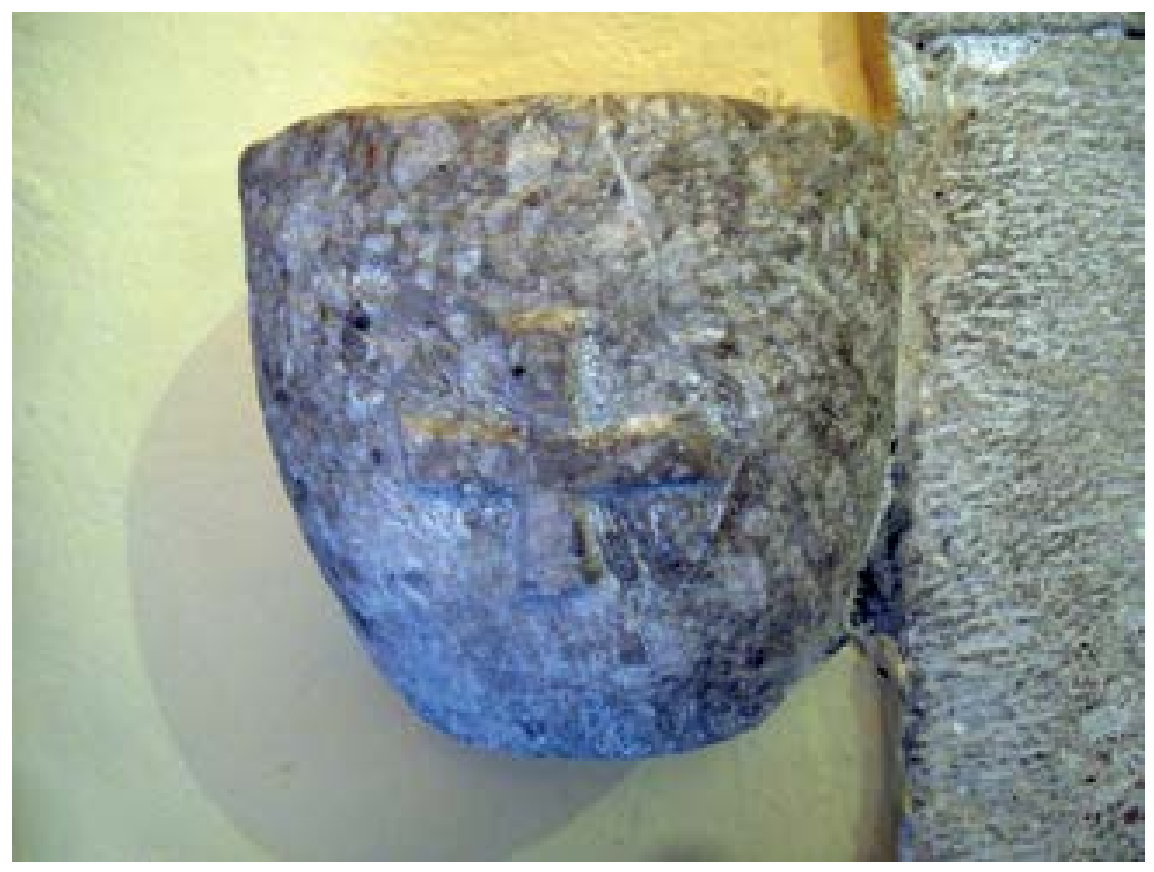

S1. 9. Gotička škropionica iz crkve sv. Luke u Kučićima (foto: Marinko Tomasović)

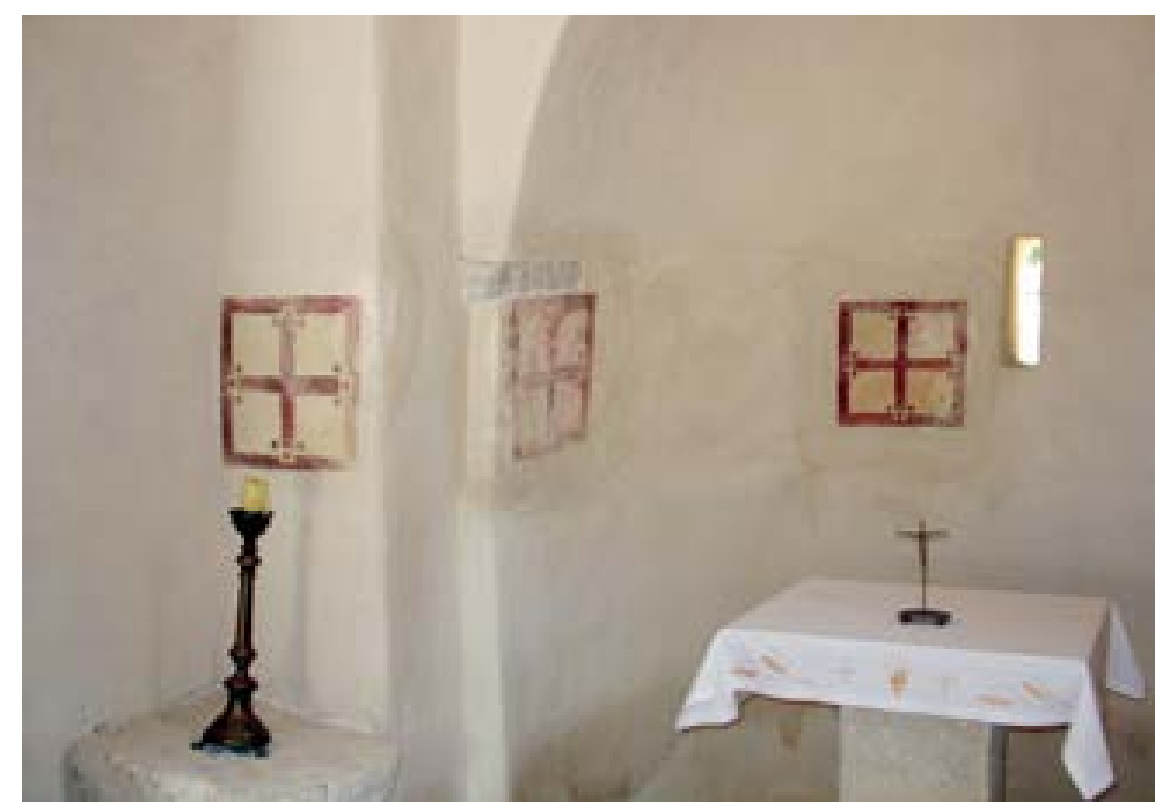

S1. 10. Oslikani gotički križevi u crkvi sv. Jurja u Tučepima (foto: Marinko Tomasović) 
Reljefni križ na njoj također je gotovo istostranični, tzv. grčki tip, dok skromni izgled bazena govori o prosječnom uređenju i opremi crkava toga vremena, zacijelo u skladu sa skromnim mogućnostima njihovih malih zajednica.

Primjeri gotičkoga slikarstva zastaju na oslikavanju freskama dvaju primorskih crkava. Romaničkoj Sv. Jurja u Tučepima prilikom obnove, gradnje prelomljenog svoda, oslikani su na zidovima unutrašnjosti posvetni križevi unutar kvadratnih polja (slika 10). Devet sačuvanih križeva, završetcima nalik pupoljcima kao i odabirom crvene boje za oslikavanje, karakteristični su za gotiku. Datirani su u 14. st., ${ }^{48}$ iako se možda pri tome više povodilo za pretpostavljenim vremenom obnove crkve. Naknadno im se, stoga, datacija provukla i u 15. st. ${ }^{49} \mathrm{Za}$ očitovanje gotičkoga stila reprezentativniji su oslikani križevi i drugi motivi u predromaničkoj crkvi sv. Ivana u Podaci. $\mathrm{Na}$ njezinim unutrašnjim zidovima, pročelnom (slika 11-12), sjever-

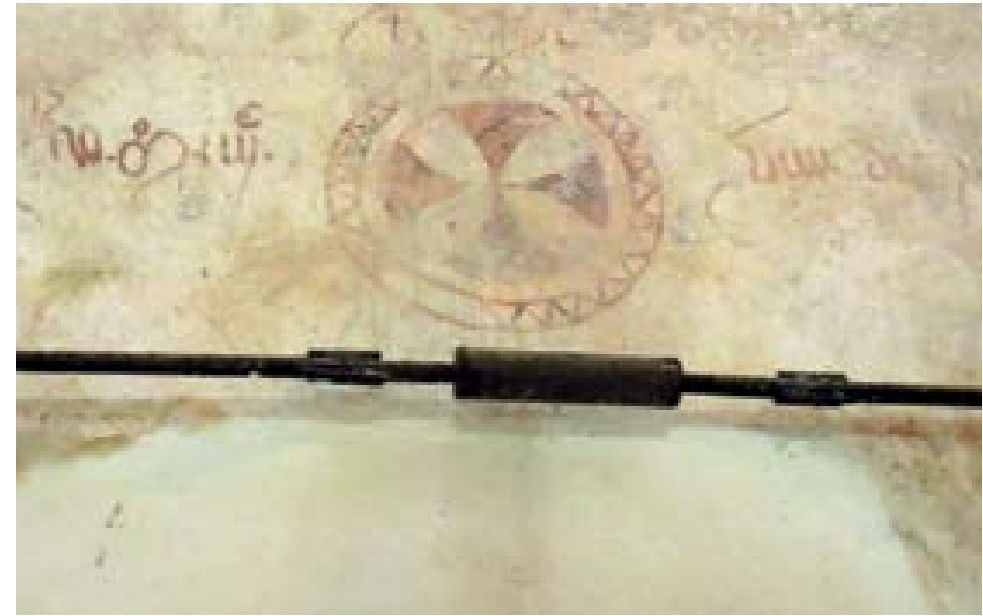

S1. 11. Oslikani gotički križ iznad vrata crkve sv. Ivana u Podaci (foto: Marinko Tomasović)

48 Zoraida Demori-Staničić - Anita Gamulin, "Crkva Sv. Jure u Tučepima", u: Konzervatorski bilten Regionalnog zavoda, 14, Split, 1993.; Anita Gamulin, "Istražni i zaštitni konzervatorski radovi na crkvi Sv. Jurja u Tučepima", u: Makarsko primorje, 2, Gradski muzej Makarska, 1995., str. 16. Nevenka Bezić, "Crkva sv. Jurja u Tučepima", u: Peristil, 5, Zagreb, 1962. str. 9, križeve pogrešno uzima za romaničke.

49 Marinko Tomasović, Vodič kroz kulturnu baštinu: Makarska i Makarsko Primorje, Biokovo i Zabiokovlje, Omiško-rogoznički i Neretvansko-stonski prostor, 2. izd., Gradski muzej Makarska, Makarska, 2015., str. 60, 63. 
MARINKO TOMASOVIĆ - GOTIČKA UMJETNOST U PRIMORJU...

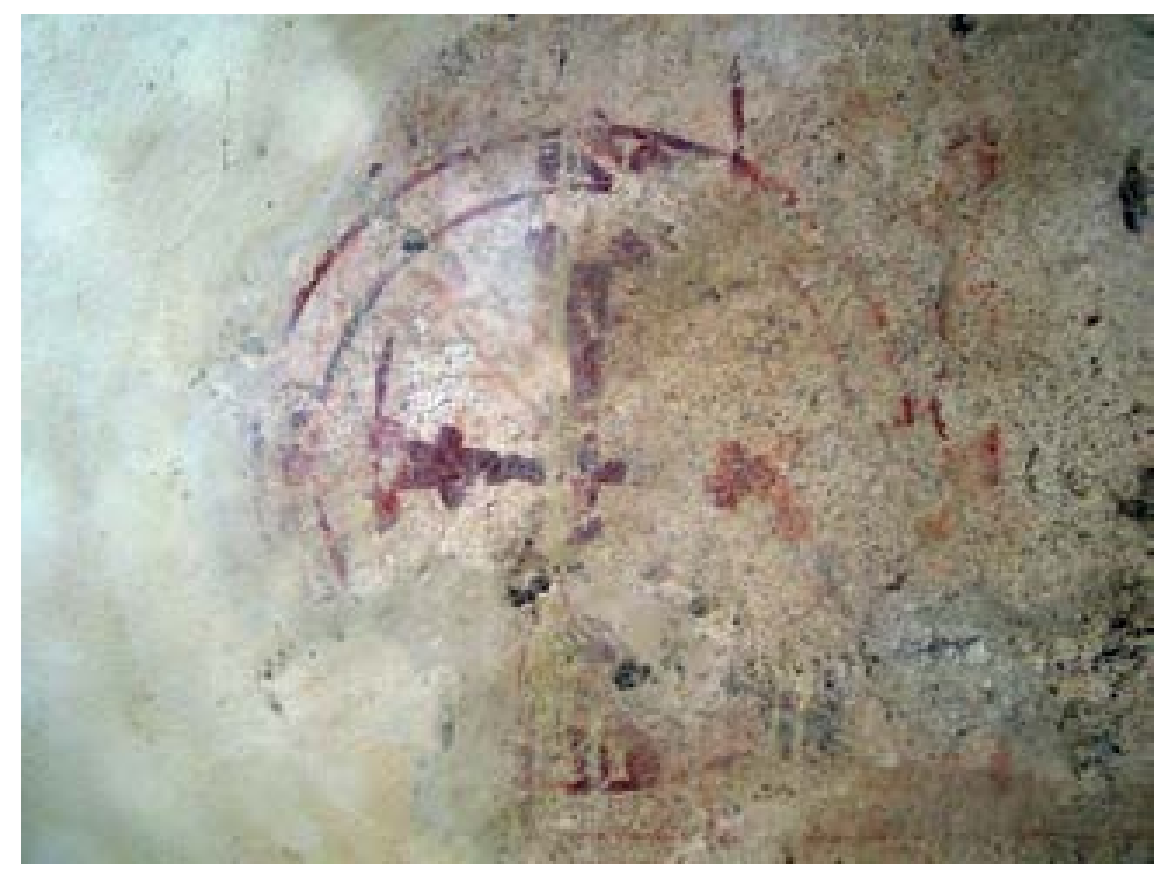

S1. 12. Oslikani gotički križ desno od vrata crkve sv. Ivana u Podaci (foto: Marinko Tomasović)

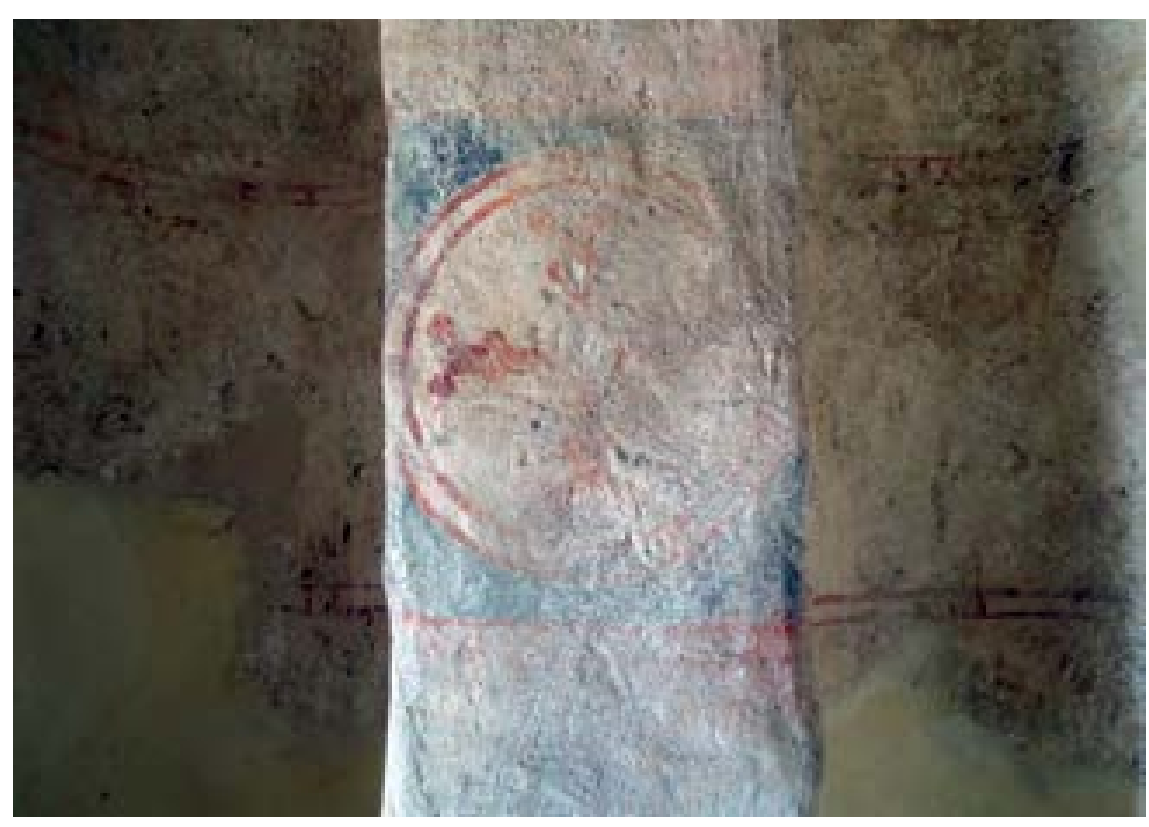

Sl. 13. Oslikani gotički križ na sjevernom zidu crkve sv. Ivana u Podaci (foto: Marinko Tomasović) 


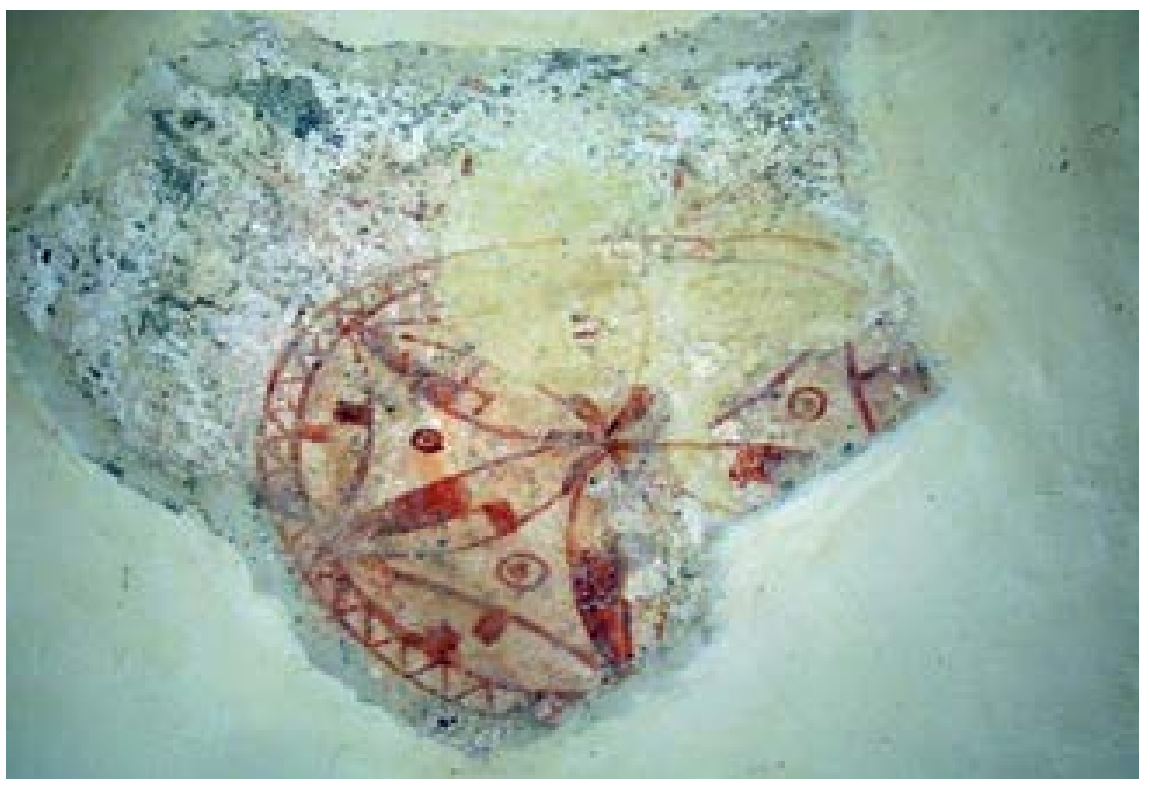

S1. 14. Oslikana gotička zvijezda u apsidi crkve sv. Ivana u Podaci (foto: Marinko Tomasović)

nom (slika 13) i u apsidi (slika 14), prilikom konzervatorskih radova obnovljena su četiri oslikana križa i šesterokraka zvijezda, zapravo kompozicija triju križeva. Uz njih je, iako u manjim dijelovima, sačuvana i dekoracija traka i crta. ${ }^{50} \mathrm{Za}$ razliku od tučepskih križeva podački motivi, neizjednačene veličine u promjerima $36-65 \mathrm{~cm}$, oslikani su u više boja. Razvedenošću i stilizacijom različitih križeva, redovito unutar dvostrukih dekoriranih kružnica, kakvu ima i zvijezda, iskazuju dio sačuvanoga, ali iznimno bogatoga dekorativnog i simbolički oslikanoga sustava. Podačka crkva oslikana je 1409., a ova se godina uspijeva čitati na inače nerazgovjetnom natpisu goticom iznad vrata, kada je negdje istih godina dekorirana posvetnim križevima i crkva u Tučepima. To što je podačka Sv. Ivana bogatija u raznovrsnosti i prikazu simbola i motiva ne znači kako oslikavanje tučepskoga Sv. Jurja treba datirati u drugo vrijeme. Uostalom, križevi desno od ulaza i na sjevernome zidu crkve sv. Ivana završetcima hasti, pupoljcima ili kuglicama, istorodni su jednostavnim i izjednačenim križevima Sv. Jurja.

50 Bosıljka Bezıć, "Predromanička crkva Sv. Ivana Krstitelja u Podaci", u: Prilozi povijesti umjetnosti u Dalmaciji, 25, Split, 1985., str. 70-76. 
Malobrojne izrađevine zlatarskoga obrta, stilski vezani za gotiku, sačuvani su u franjevačkim samostanima u Makarskoj i Zaostrogu. Makarskim liturgijskim predmetima datacija nije usklađena u okviru 15.-17. st., iako ih je većina iz kasnijeg razdoblja. ${ }^{51}$ Stoga i otpada mogućnost kako se radi o liturgijskom posuđu iz vremena dolaska ili najranijega boravka redovnika, time i izradi kojom bi se, osim nesumnjivoga stilskog izgleda, naznačila i umjetnost zlatarstva u vrijeme Kosača. ${ }^{52}$ Iz samostana Sv. Marije u Zaostrogu tek je srebrni kadionik sa sigurnošću opredijeljen kao rad 15. st. ${ }^{53}$

51 Makarski pozlaćeni kalež iz groba biskupa fra Petra Kačića (+ oko 1660.) uzeo se kao gotički iz 15. st. i dokazom "cvjetnog doba hrvatskog zlatarstva u Dalmaciji": Cvito Fisković, "Spomenici grada Makarske", u: JAKšA RAVLIĆ (prir.), Makarski zbornik, I., Znanstveno savjetovanje o Makarskoj i Makarskom primorju, 28.-30. rujna 1969., Makarska, 1970., str. 253. Potom se odredio kao kasnogotički, dok pozlaćeni pastorale iz groba biskupa fra Marijana Lišnjića (+ 1686.) i srebrno procesionalno raspelo datiraju u 15.-16. st.: Ivo Lentić, "Zlatarstvo u Franjevačkoj provinciji presvetog Otkupitelja", u: Hrvatin Gabrijel Jurišić - Josip Ante Soldo (prir.), Fra Filip Grabovac i njegovo doba, Radovi simpozija Kačić, Sinj, 30. rujna - 2. listopada 1982., Kačić, 16, Split, 1984., str. 215-217, 222, 224. Kalež je, kao rad dalmatinskih zlatarskih radionica, datiran i u početak 16. st., dok je procesionalnom raspelu fojničke radionice izrada pomaknuta u 17.-18. st., kao i biskupskom štapu, djelu bosanske radionice, u 17. st.: Zoraida Demori-STAničić, "Srebrni liturgijski predmeti iz riznice Franjevačkoga samostana u Makarskoj", u: Hrvatin Gabrijel Jurišić (prir.), Franjevci i Makarska od 1502. do 2002. godine, Radovi Znanstvenoga skupa Franjevci i Makarska u prigodi pet stoljeća prvoga pisanog spomena franjevaca u Makarskoj, Makarska 17.-20. listopada 2002., Kačić, 36-38, Split, 2004.-2006., str. 660, 665, 670.

52 Možda je datacija kaleža iz groba biskupa Lišnjića u početak 16. st. iznijeta u pogledu tvrdnje o nabavkama liturgijskih predmeta tek od 1502., kojom se neoprezno označio početak "službenog" boravka, umjesto prvog spomena franjevaca u Makarskoj: Z. DEMORI-STANičıć, "Srebrni liturgijski predmeti iz riznice Franjevačkog samostana u Makarskoj", str. 648.

53 KARLO JuRIŠić, Franjevački samostan Zaostrog, Zaostrog, 1981., str. 11; Ivo Lentić, "Zlatarstvo u Franjevačkoj provinciji presvetog Otkupitelja", str. 219. Primjereniju ekspertizu nego što je učinjena zahtijevaju dva križa, pacifikala, iz zbirke samostana u Zaostrogu: DEšA DiAnA, "Liturgijska franjevačka baština na relaciji Split - Sinj - Zaostrog", u: ZDENKo RADELIĆ (prir.), Hrvatski rasadnik - Zbornik članaka znanstvenoga skupa Gornje makarsko primorje, Gradac - Zaostrog, 26. 9. - 27. 9. 1996., Zagreb, 1999., str. 99, pri čemu se za njihovu stilsku oznaku rabi termin gotika, a da ih se nije ni nastojalo datirati. 


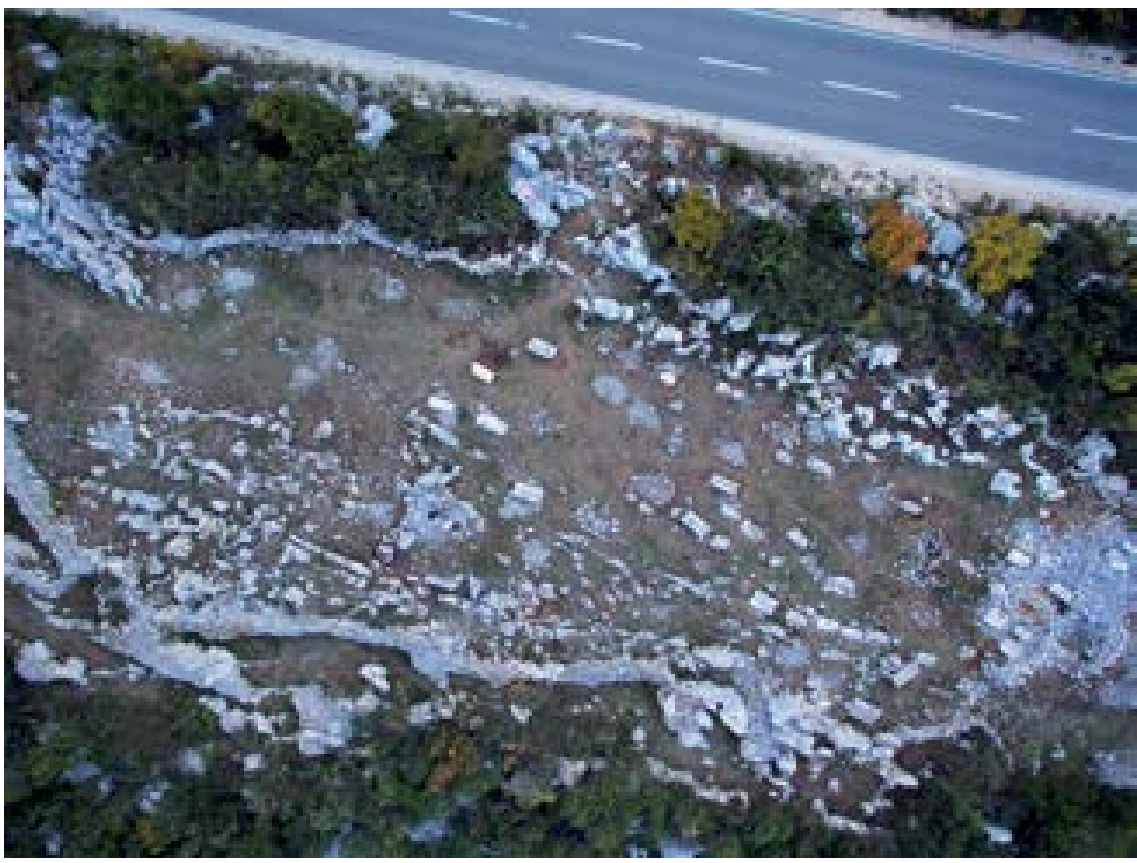

S1. 15. Groblje s bilizima (stećcima) u Crnoči (Staševica) (foto: Tehno Trend D. o. o., Dubrovnik)

\section{Nadgrobni spomenici}

Na kraju ovoga preglednog izlaganja o gotičkoj umjetnosti i njezinim indicijama u Primorju, Radobilji i Gorskoj župi, uopćeno će se obuhvatiti i njezina brojčano najimpresivnija, a likovnošću i kontekstom nastanka zasigurno najreprezentativnija baština iskazana u nadgrobnim spomenicima, bilizima (stećcima) i pločama kao najčešćim (slika 15), te drugim rjeđim primjerima obilježavanja grobova. O njima se za ovaj prostor odnedavno i najsustavnije pisalo, problemskim pristupom i kontinuirano topografskim prinosima. ${ }^{54}$

54 M. Tomasović, Srednjovjekovni nadgrobni spomenici u Makarskom primorju, 2007.; JosiP Bulog, "Prilog poznavanju kamikâ Vrgorske krajine", u: Starohrvatska prosvjeta, III. s., 34/2007., Split, 2007., str. 389-420; MARINKO Tomasović - Domagoj Perkić - Ivan Alduk, "Topografija stećaka u Hrvatskoj", u: Jasminka PoklečKi Stošić (prir.), Stećci, katalog izložbe, Galerija Klovićevi dvori (4. IX. - 2. XI. 2008.), Zagreb, 2008., str. 68, 77-96; MARINKO Tomasović, "Srednjovjekovni nadgrobni spomenici makarsko-neretvanskog područja", u: Jasminka PoklečKi Stošıć (prir.), Stećci, katalog izložbe, Galerija Klovićevi dvori (4. IX. - 2. XI. 2008.), Zagreb, 2008., str. 120-129; MAJA 


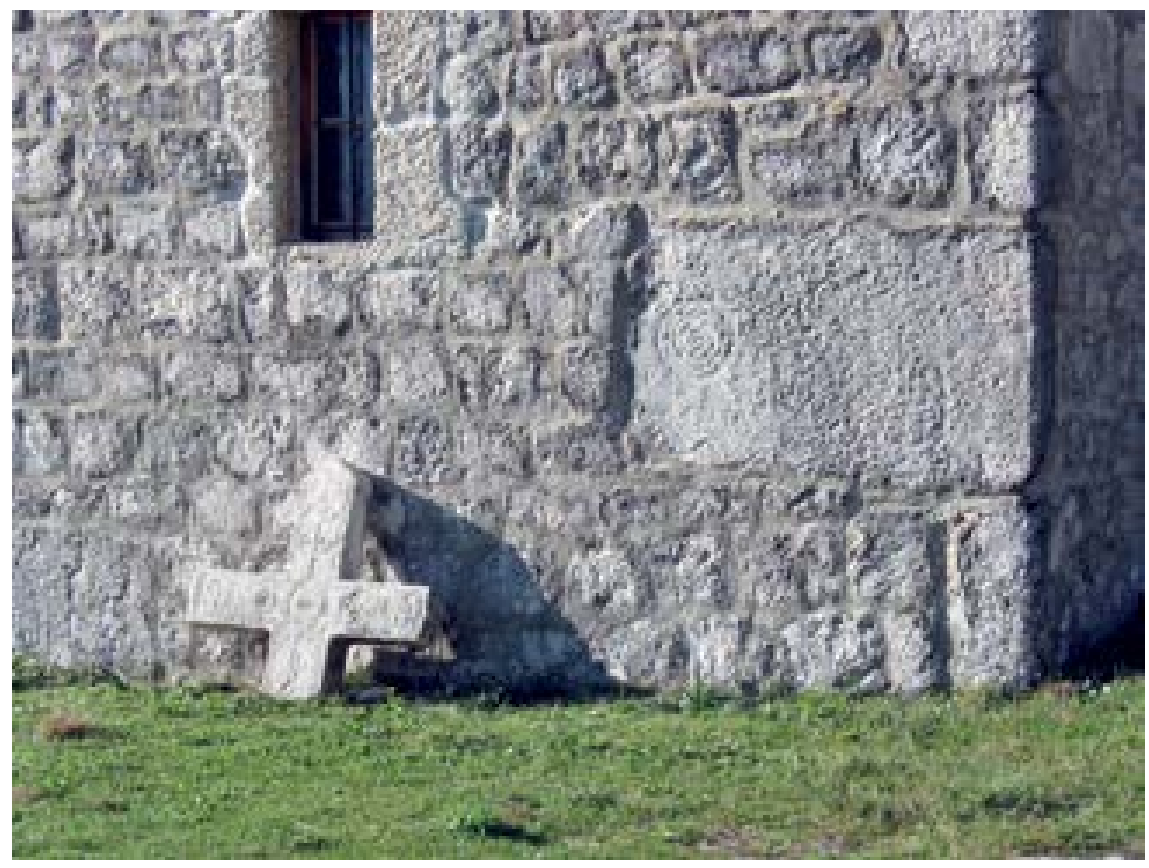

Sl. 16. Bilig (stećak) uzidan u crkvu sv. Mihovila u Rašćanima (foto: Marinko Tomasović)

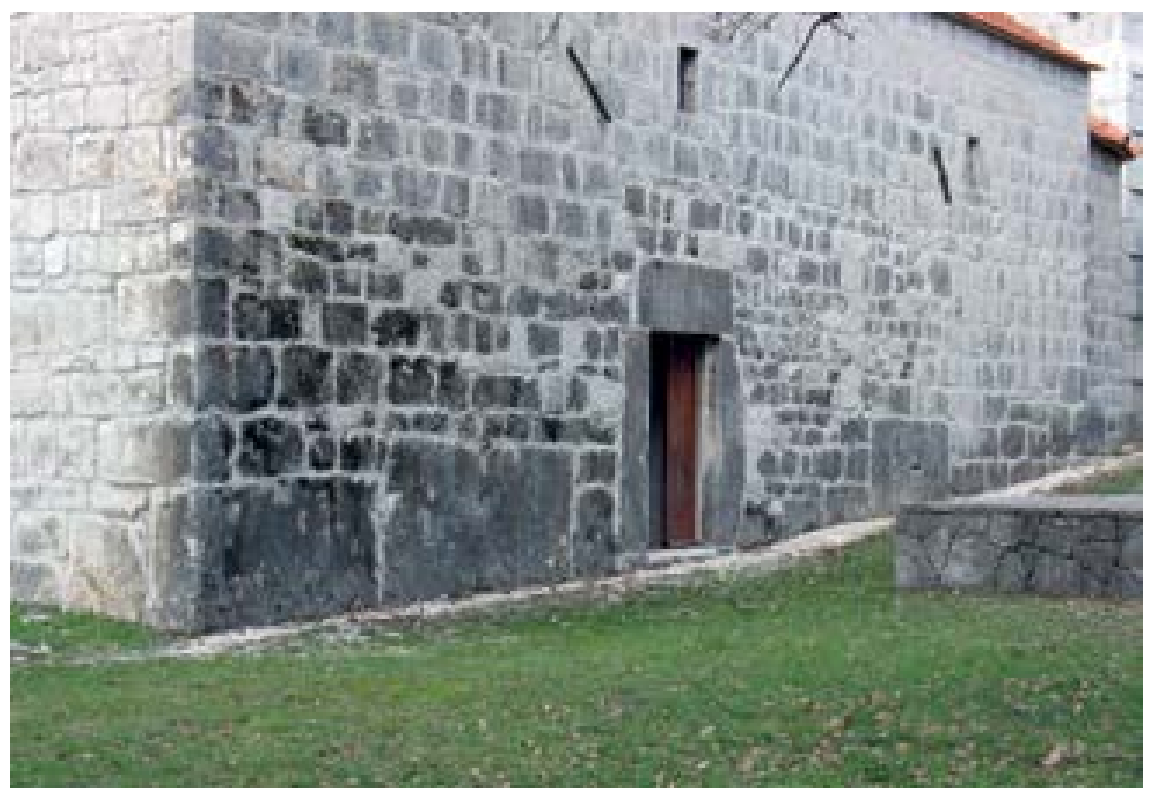

Sl. 17. Bilizi (stećci) uzidani u crkvu sv. Stjepana u Rašćanima (foto: Marinko Tomasović) 


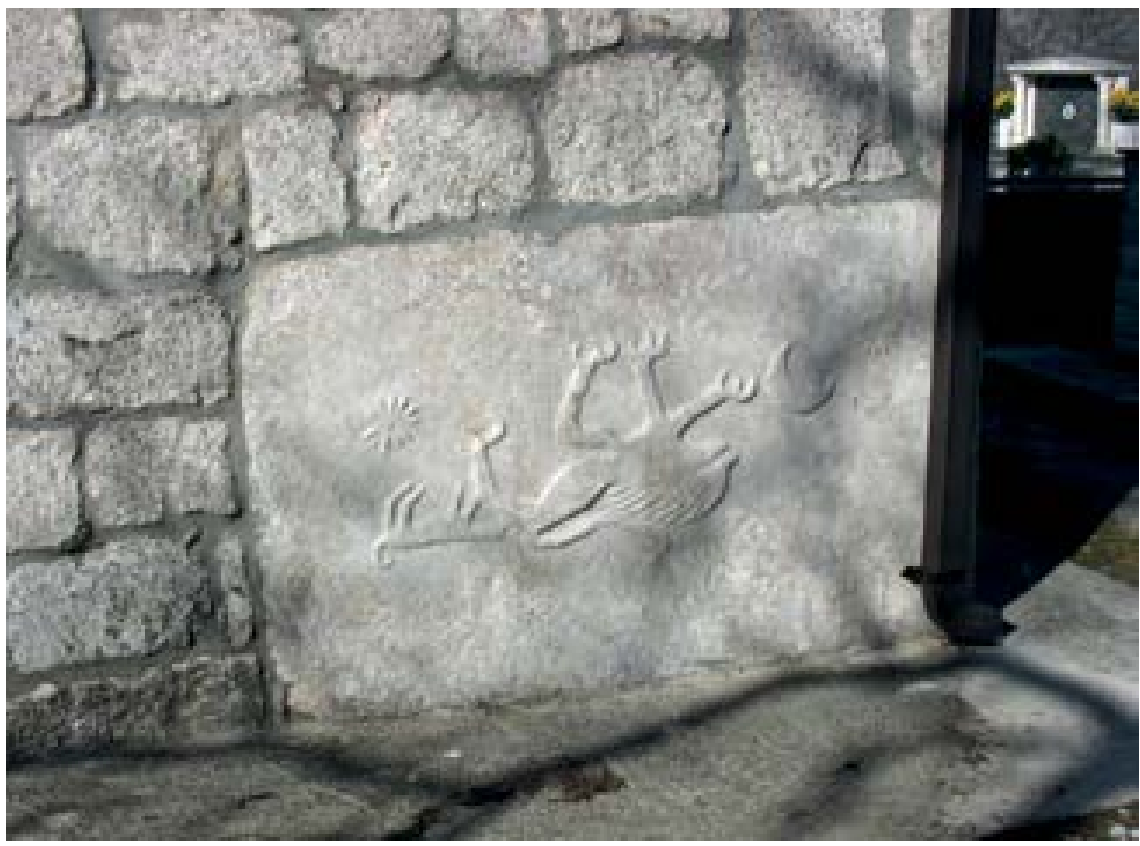

S1. 18. Bilig (stećak) uzidan u crkvu Svih Svetih u Kljenku (foto: Marinko Tomasović)

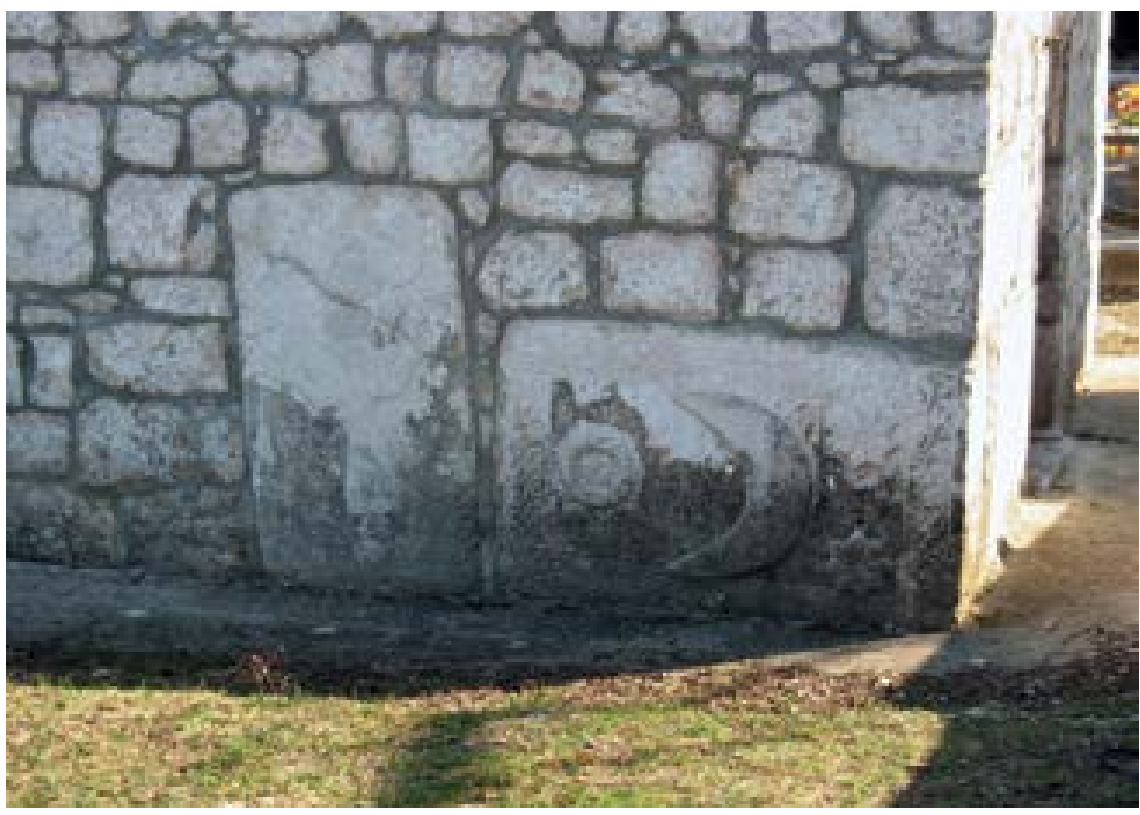

Sl. 19. Bilizi (stećci) uzidani u crkvu Svih Svetih u Kljenku (foto: Marinko Tomasović) 
Stoga će tek biti riječi o nekim temeljnim aspektima korisnim za razumijevanje likovnosti biliga, kao poticaju za buduće, još određenije kulturno i kronološko razvrstavanje. Činjenicom kako su ugrađivani i u crkve potpomoći će, barem upozorenjem, na temelje ranijih gradnji čije spomene ne nalazimo u starijim izvorima (slike 16-19).

ŠunjIć, "Srednjovjekovni nadgrobni spomenici-stećci na lokalitetu Grebine pored Čeveljuše (Plina) kod Ploča", u: Opuscula archaeologica, 32, Arheološki zavod Filozofskog fakulteta Sveučilišta u Zagrebu, Zagreb 2008., str. 133-166; Marinko Tomasović, "Stećci na Grebinama u Čeveljuši i kod crkve sv. Ivana u zapadnoj Plini", u: Starohrvatska prosvjeta, III. s., 35/2008., Split, 2008., str. 167-183; Ante MilošEvić - Jure Šućur, "Lokalitet: Mišja Draga - prapovijesne gomile; Naselje: Šarića Struga; Grad/općina: Ploče; zaštitno iskopavanje", u: Hrvatski arheološki godišnjak, 5/2008., Ministarstvo kulture Republike Hrvatske, Zagreb, 2009., str. 699-701; MARinko Tomasović, "Stećci i ploče - Nadgrobni spomenici srednjeg vijeka na Makarsko-neretvanskom području", u: Hrvatska revija, Matica hrvatska, IX/1, Zagreb, 2009., str. 6469; M. Tomasović, "Kasnosrednjovjekovne nadgrobne ploče starog omiškog i rogozničkog groblja", str. 92-105; Goran Novović - MARInko TomasoviĆ, "Stećci u Kozici (Vrgorska krajina)", u: Makarsko primorje, 9, Makarska, 2010., str. 55-93; Ivan Alduk, "Kovač iz Gorske župe", u: Prilozi povijesti umjetnosti u Dalmaciji, Konzervatorski odjel Split Ministarstva kulture Republike Hrvatske - Književni krug Split, 42, Split, 2011., str. 161-186; MaJA BiLIĆ - Ante Ivišıć - Šime Vulić, "Arheološka istraživanja u Istočnoj Plini s posebnim osvrtom na groblja kasnog srednjeg vijeka", u: MARINKo ToMAsović (prir.), Arheološka istraživanja na trasi autoceste u Zabiokovlju i Plini, Gradski muzej Makarska, Makarska, 2011., str. 263-266; MARinko ToMAsović, "Kasnosrednjovjekovno groblje u tumulu 1 na Ogradi (Dražice) u Eracima (Istočna Plina)", u: Marinko Tomasović (prir.), Arheološka istraživanja na trasi autoceste u Zabiokovlju i Plini. Katalog izložbe, Gradski muzej Makarska, Makarska, 2011., str. 307-311; MARınko Tomasović, "Crkva sv. Bartula i stećci na Krvavcu u Milušoj (Pasičina)", u: Staševica, List župe Sv. Staša u Staševici, 1(8), Staševica, 2013., str. 13-18; MARInko TomAsović, "Tangàrija u Milušoj (Pasičina) - Gradina, bojadisaonica i groblje", u: Hrvatski neretvanski zbornik, 6, Društvo Neretvana i prijatelja Neretve u Zagrebu, Zagreb, 2014., str. 110-112; Marinko Tomasović, "Greblje u Milušoj (Pasičina) - ukopište iz prapovijesti i sa stećcima iz kasnog srednjeg vijeka", u: Staševica, List župe Sv. Staša u Staševici, 1(9), Staševica, 2014., str. 37-44; Marinko Tomasović, "Arheološka i povjestna topografija Desana", u: STJEPAn ŠEŠELJ (prir.), Fra Jeronim Šetka - hrvatski franjevac, svećenik, profesor, jezikoslovac i književnik. Zbornik radova jedanaestog Neretvanskog književnog, znanstvenog i kulturnog susreta izlaganih 24.-26. rujna 2015., Neretvanska riznica umjetnina i inih vrijednosti - Hrvatska kulturna zaklada - Južnohrvatski ogranak DHK Ston - Franjevačka klasična gimnazija Sinj - Matica hrvatska Neum - Hrvatsko slovo, Zagreb - Kula Norinska, 2016., str. 233-236; MARINko Tomasović, "Kasnosrednjovjekovna križina na groblju Svih Svetih na Bristi", u: Staševica, List župe Sv. Staša u Staševici, 1(11), Staševica, 2016., str. 23-28. 
Valja podsjetiti kako su u pogledu etničkih nositelja prepoznate indicije u odvojenom grupiranju biliga (stećaka) i ploča, različitih vrsta nadgrobnih spomenika, iskazanih u Primorju (Makarskom primorju). Kada je riječ o bilizima, iznijet je prijedlog za njihovu pripadnost Vlasima, dok se u nadgrobnim pločama prepoznala nesumnjiva vezanost za domorodački etnikum, nerijetko s heraldičkim obilježjima na njima (slika 20-21). ${ }^{55} \mathrm{Za}$ Vlahe, pokretljivu stočarsku populaciju, izvori od polovice 15. st. upućuju na postojanje nahija i u Primorju, Radobilji i Gorskoj župi. ${ }^{56}$ Veće migracije Vlaha iz zaleđa u Primorje potaknute su sukobima s Osmanlijama. Vlasi, čiji je broj izrazit u trajanju vlasti hercega Stjepana Kosače u Humu, a i u vrijeme hercega

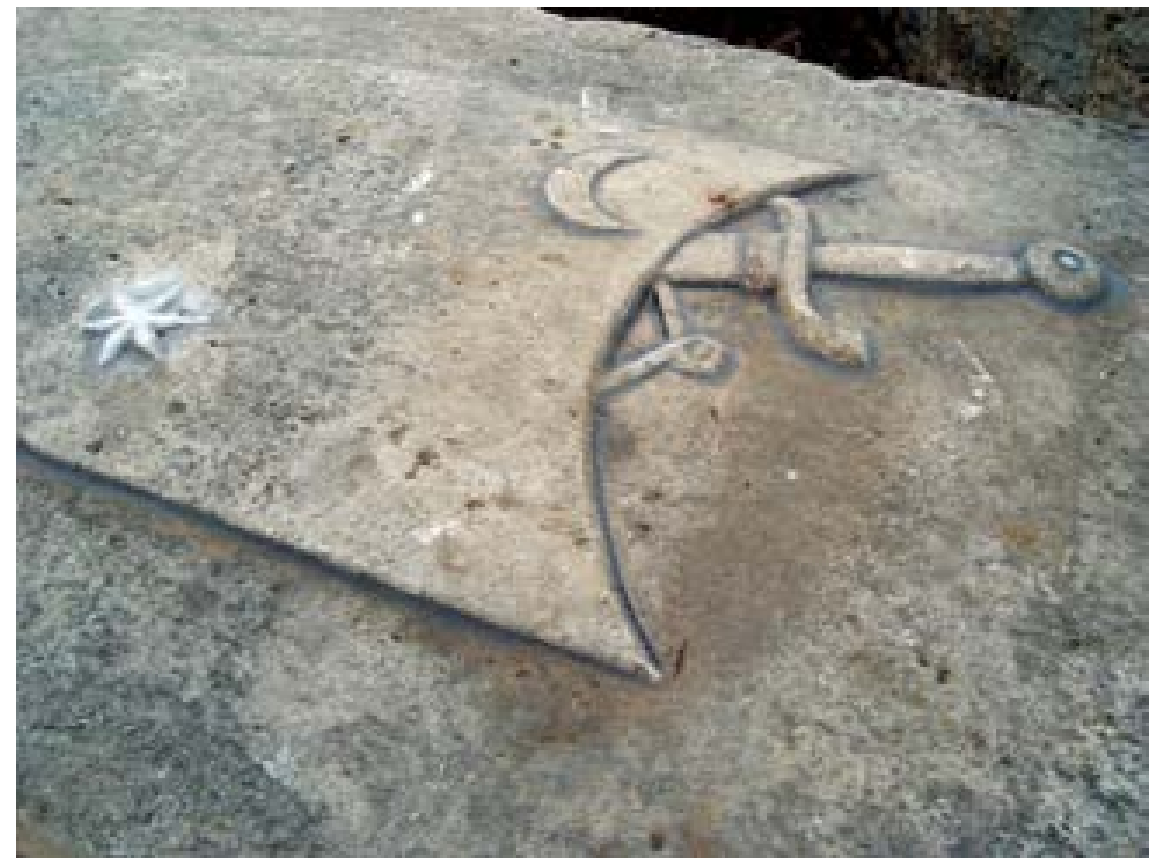

Sl. 20. Nadgrobna ploča s groblja kod crkve sv. Stjepana u Brelima (foto: Marinko Tomasović)

55 M. Tomasović, Srednjovjekovni nadgrobni spomenici u Makarskom primor$j u$, str. 77-78.

56 ŠPIRo Kulišıć, "O nekim problemima etničkog razvitka našeg dinarskog stanovništva i njegovih odnosa sa balkanskim starinicima", u: Godišnjak Centra za balkanološka ispitivanja Akademije nauka i umjetnosti Bosne, V./3, Sarajevo, 1967., str. 206. 


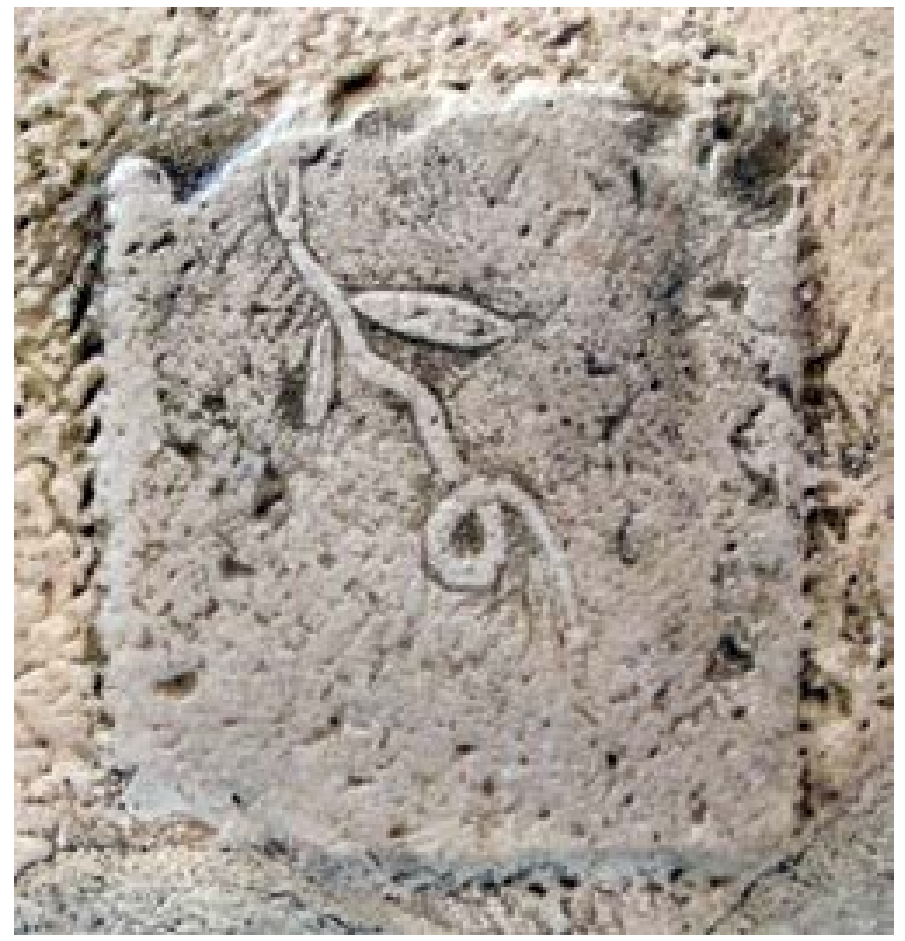

S1. 21. Nadgrobna ploča s grbom Kačića u crkvi sv. Petra u Makarskoj (foto: Brankica Pejković)

Vlatka, suprotstavljaju se osmanlijskom uvođenju timarskoga sustava. ${ }^{57}$ Pojedinačni spomen sela u Primorju i Gorskoj župi u defteru iz 1477. govori kako su pripadala vlaškim katunima, odnosno vremenu do kojega su Osmanlije proširile vlast u krajevima od Neretve sve do Cetine. ${ }^{58}$ Među njima su primorska Brela i Bast, Tučepi i Drašnice, te Rašćane i Vrhdol kao mjesta s evidentiranim bilizima. Stupanj znanstvenoga istraživanja još uvijek ne može odgovoriti na pitanje

57 Nedim Filipović, "Vlasi i uspostava timarskog sistema u Hercegovini, I.", u: Godišnjak Centra za balkanološka ispitivanja Akademije nauka i umjetnosti Bosne, XII./10, Sarajevo, 1974., str. 160-161.

58 N. Filipović, "Vlasi i uspostava timarskog sistema u Hercegovini, I.", str. 166, 188. O vlaškim katunima kroz prizmu geneoloških razmatranja, poglavito za južnije priobalje vidi: STJEPAn Ćosıć, Ideologija rodoslovlja - Korjenić-Neorićevgrbovnik iz 1595., Zavod za povijesne znanosti HAZU u Dubrovniku - Nacionalna i sveučilišna knjižnica u Zagrebu, Zagreb - Dubrovnik, 2015., str. 143-146. 
udjela vlaške populacije na ovom prostoru (pretpostavljene kao nositelja etničke skupine koja se glavninom pokapala pod bilizima) i $\mathrm{u}$ nešto ranijem razdoblju, prihvati li se uvriježena datacija biliga $\mathrm{u}$ vrijeme od kraja 14. do druge polovice 15 . st. Za pretpostaviti je (ili to valja podrazumijevati) ranije prisustvo Vlaha u predjelima zapadno od donjega toka Neretve, iako pri tome pojedina pitanja zahtijevaju odgovore temeljene na kompleksnijim istraživanjima. Jedno od njih odnosi se i na izostanak biliga uz donji tok Cetine (prostor sela Kučiće i Svinišća), na dijelu radobiljskoga prostora iste strane (selo Slime), te priobalnom rogozničkom prostoru. Ovaj problem nije ni naznačen $u$ literaturi, a izravno stoji $u$ vezi pitanja o prisustvu Vlaha na tome prostoru, ne samo od sredine 15. st., nego i u ranijim razdobljima, uostalom kako je i istaknuto za susjedno Makarsko primorje. $\mathrm{U}$ arheološkoj literaturi nazočnost Vlaha na prostoru lijeve strane donjega toka Cetine tek se sugerirala, iako nekoegzistentno. ${ }^{59}$

Kontekst datiranja biliga (stećaka) u zapadnom Humu sukladan je i vremenu vladavine hercega Stjepana Kosače, a stilske poveznice spomenika u Primorju i Gorskoj župi sa širim humskim ili hercegovačkim prostorom, osobito ljubuškim, ukazuju i na isto, ili barem

59 Riječ je o istraživanjima Greblja u Kučićima, na kojemu se ukopavanje isprva odredilo u 12.-14. st., potom do sredine 14. st., te konačno distingviralo svojom mlađom fazom od druge polovine 13. do kraja 14. st., odnosno početka 15. st.: Vedrana Delonga, "Srednjovjekovno groblje u Kučićima - novo arheološko nalazište u omiškom zaleđu", u: Mosorska vila, II./5-6, Centar za kulturu, Omiš, 1993., str. 155; Vedrana Delonga, "Srednjovjekovno groblje u Kučićima - novo arheološko nalazište u omiškom zaleđu", u: Zov rodnih ognjišta, List župe Sv. Luke - Kučiće, V./1(8), Kučiće, 1999., str. 21; VedRANA Delonga, "Arheološka istraživanja u Kučićima", u: Starohrvatska prosvjeta, III. s., 27, Split, 2000., str. 73, 75. Tek se u novijem radu, neznatno dopunjenoj verziji ranijih tekstova, pretpostavilo kako je groblje pripadalo novopridošlom stanovništvu, izravnim sugeriranjem kako se (u prvom redu u pogledu grobnih daća) radilo o Vlasima. Ovaj zanimljivi problem, na žalost, ostao je nedorečen samom činjenicom što se na njega više nije navraćalo, a opterećen i nekim topografsko-kronološkim nesporazumima, o čemu je bilo govora: Marinko Tomasović, "Arheološka topografija lijeve strane donjeg toka Cetine", u: Jacqueline Balen - Hrvoje Potrebica (prir.), Arheološka istraživanja u Cetinskoj krajini, Izdanja Hrvatskog arheološkog društva, 27, Hrvatsko arheološko društvo - Muzej Cetinske krajine, Filozofski fakultet Sveučilišta u Zagrebu, Zagreb, 2011., str. 243-245; M. Tomasović, "Arheološka istraživanja u Kučićima: otkriće temelja crkve Sv. Luke iz 14.-15. st.", str. 23-25. 


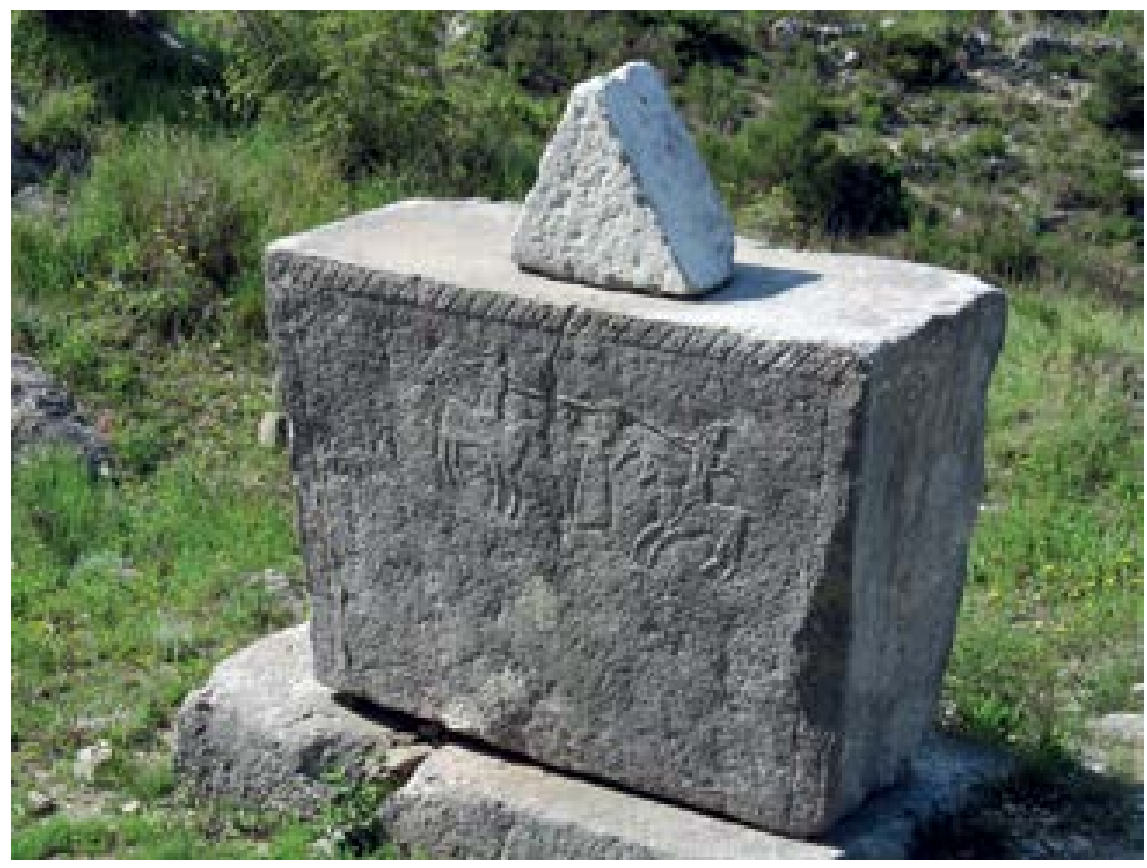

S1. 22. Bilig (stećak) na Kostanića grebu u Drveniku (foto: Brankica Pejković)

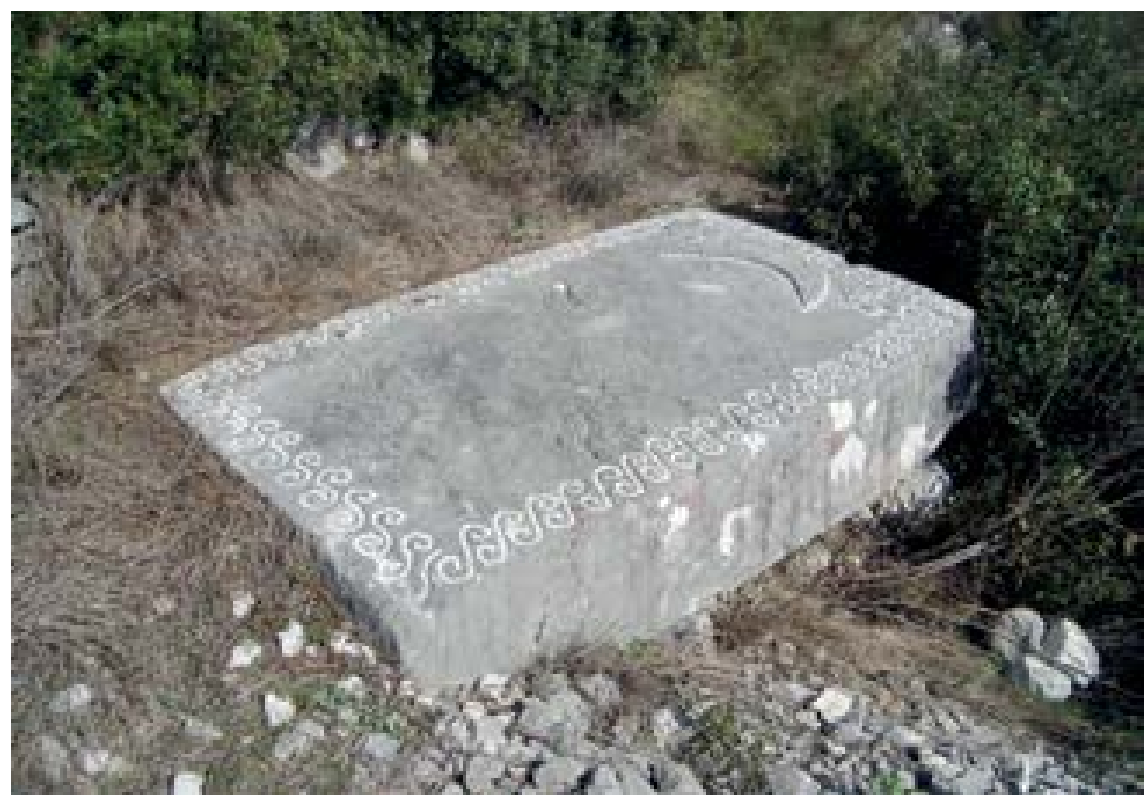

Sl. 23. Bilig (stećak) iz Brista (foto: Marinko Tomasović) 


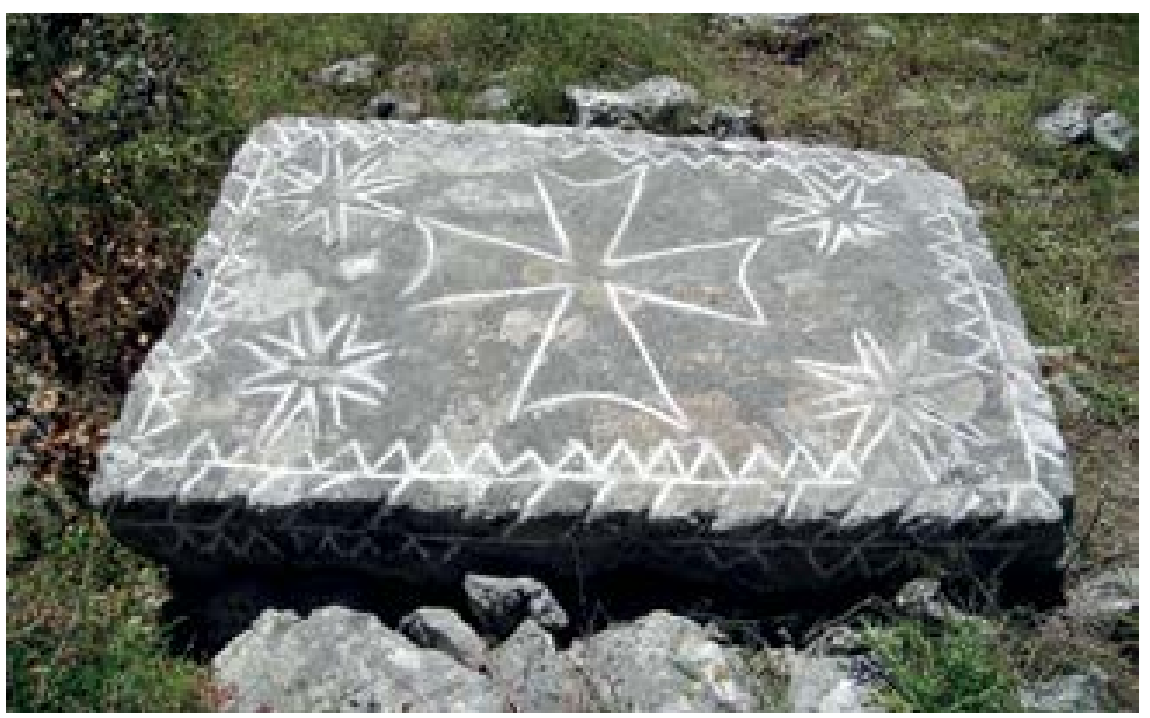

S1. 24. Bilig (stećak) na Crnoči (Staševica) (foto: Marinko Tomasović)

veoma srodno, radioničko okruženje (slike 22-24). ${ }^{60}$ Podrobnijom analizom ukrašavanja na ovaj likovni krug upozorio je i Ivan Alduk, čiji se zaključci o izglednoj izradi biliga i duže od polovice 15. st. posve uklapaju u ovdje naznačeni problem njihove prostorne i vremenske disperzije ${ }^{61}$ zahvaćene na prostoru pod izravnom vlašću hercega Stjepana Kosače. Podsjećanje na brojne tipološke analogije i raznolikost motiva, kao i "sporednih" likovnih uzoraka, uopće determinaciji nadgrobnih spomenika 15. st. u Primorju, Gorskoj župi i Radobilji kao krugu gotičke umjetnosti, u ovoj je prilici svakako izlišno. Tek u prilog nešto udaljenijih poveznica, ali $s$ istoga geopolitičkog sustava Kosačine vladavine, valjalo bi istaknuti do sada nespomenute sličnosti u oblikovanju kamenih križina. Neovisno o njihovoj (dvojbenoj) tipološkoj determinaciji kao stećaka, činjenica je kako se vremenskom i kulturnom pojavom uglavnom uklapaju u njihov krug. Na donjoneretvanskom prostoru istaknute su križine

60 M. Tomasović, "Srednjovjekovni nadgrobni spomenici makarsko-neretvanskog područja", str. 124-126; M. Tomasović, "Stećci na Grebinama u Čeveljuši i kod crkve sv. Ivana u zapadnoj Plini", str. 174-177.

61 I. Alduk, "Kovač iz Gorske župe", str. 183-184. 


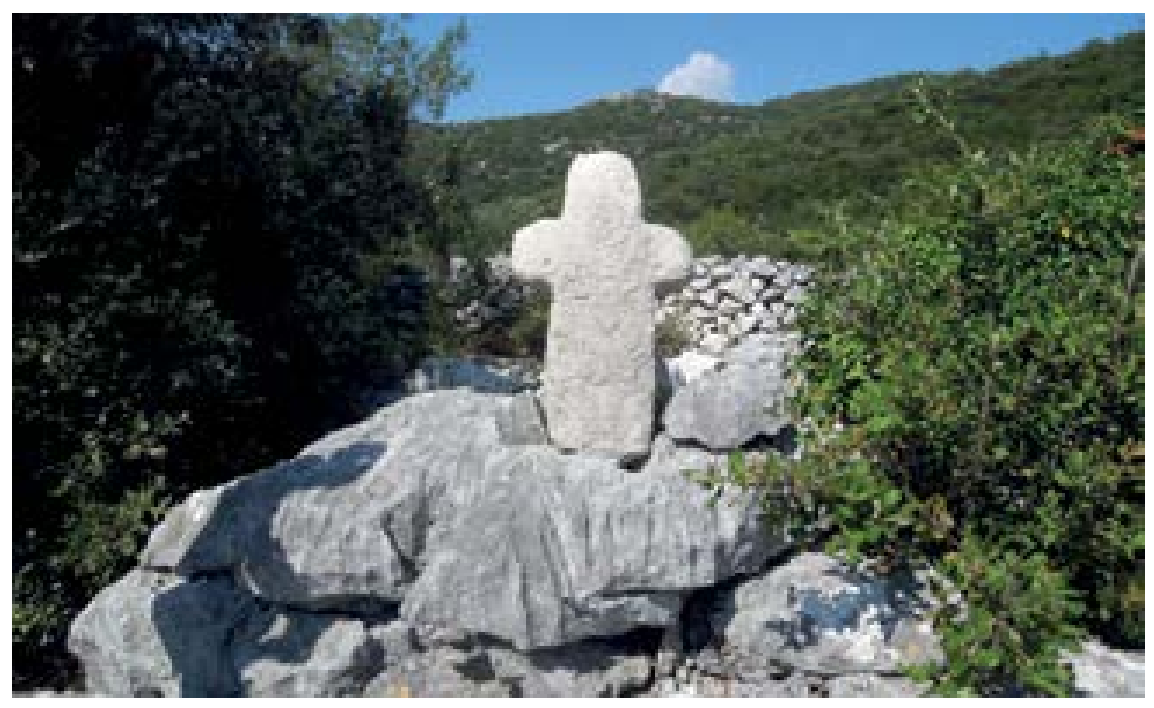

S1. 25. Križina s Grebina u Perki (zapadna Plina) (foto: Marinko Tomasović)

sa zaobljenih hastama i stražnjom stranom (slika 25). ${ }^{62}$ Nalik su primjercima u istočnoj Hercegovini, ${ }^{63}$ čime predstavljaju tipološki i uže kulturni antipod učelcima s gotičkim rascvjetalim reljefnim križevima, evidentiranim u Primorju kao klesarskim radovima prispjelim s matičnog dubrovačkog primorja (slike 26-27). ${ }^{64}$ Datacijom ćiriličnoga natpisa iz Huma u prijelaz 15.-16. st. dobiva se uži vremenski okvir izrade ovoga tipa križine. Svakako, on još uvijek zastaje u širem kontekstu izrade biliga (stećaka) u ovom dijelu Hercegovine, pri čemu je

62 M. Tomasović, "Kasnosrednjovjekovna križina na groblju Svih Svetih na Bristi", str. 23-28.

63 Šefik BeŠLagić, Popovo, Srednjovjekovni nadgrobni spomenici Bosne i Hercegovine, VIII., Zavod za zaštitu spomenika kulture Bosne i Hercegovine, Sarajevo, 1966., str. 132, sl. 34, 54; 86-87; Radmilo Pekić, "Nekropola u srednjovjekovnoj župi Fatnica (ćirilica)", u: Tribunia, 10, Muzej Hercegovine Trebinje, Trebinje, 2003., str. 96, 103, sl. 2; Đuro Tošıć, Trebinjska oblast u srednjem vijeku (ćirilica), Istorijski institut SANU, Posebna izd., knj. 30, Beograd, 1998., str. 45. Moguće je auktoru križina poznata terenskim uvidom, jer joj izostaje opis u starijoj literaturi na koju se referira: OBREN ĐURIćKozıć, "Šuma, Površ i Zupci u Hercegovini (ćirilica)", u: Srpski etnografski zbornik, V., Naselja srpskih zemalja, knj. 2, Beograd, 1903., str. 1151.

64 M. Tomasović, Srednjovjekovni nadgrobni spomenici u Makarskom primorju, str. 28, 50-51, 66, 88, 98-99, T. III, 2; T. XIV, 1. 


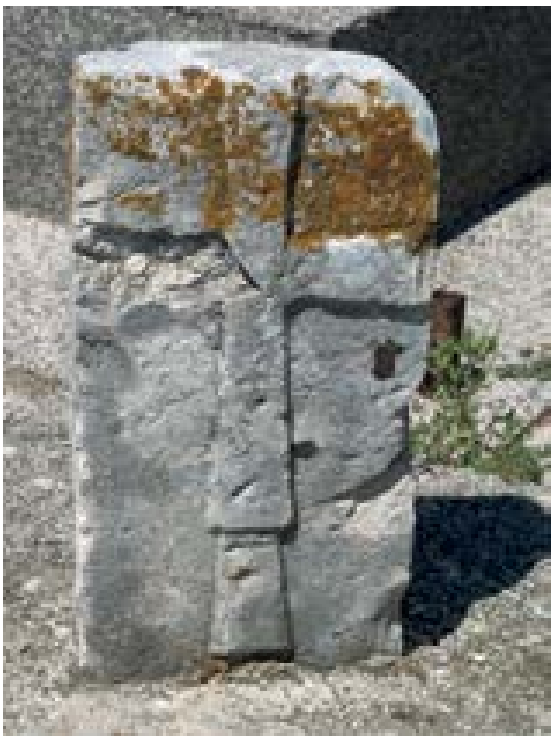

S1. 26. Grobni učelak na groblju u Bastu (foto: Marinko Tomasović)

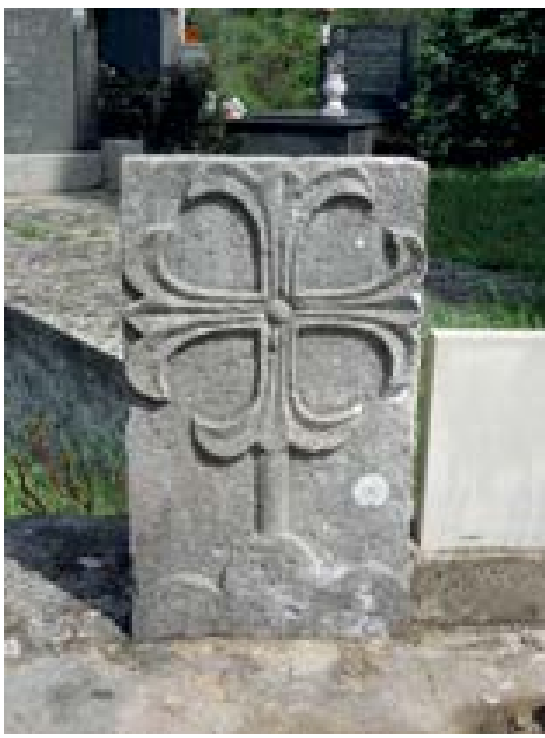

S1. 27. Grobni učelak na groblju u Drveniku (foto: Marinko Tomasović)

istaknuto vrijeme Hercega Stjepana Kosače i Vlatka Kosače ${ }^{65}$ Ono se podrazumijeva i za područja desne obale rijeke Neretve, ljubuškog prostora i Gorske župe, na kojemu je obitelj knezova Jurjevića (Vlatkovića), ojačana upravo politikom hercega Stjepana Kosače i nasljednika, i "omogućila" izradu glavnine nadgrobnih spomenika, ${ }^{66}$ čije se izravne analogije razaznaju na bilizima (stećcima) u Primorju.

\section{Utvrde uz Cetinu, u Gorskoj župi i na donjoneretvanskom prostoru u doba hercega Stjepana Vukčića Kosače}

U vremenu Stjepana Vukčića Kosače u Omišu već postoje dvije utvrde, Peovica (slike 28-29) i uzdignutiji Starigrad (slika 30). Obje su morale preuzeti ulogu u obrani grada tijekom vojnog nasrtaja ovoga bosanskog velikaša. Tvrđava Starigrad (castrum Stary; civitate An-

65 Š. BeŠLAgić, Popovo, str. 86-87, 95.

66 Маrкo Vego, Ljubuški, Srednjovjekovni nadgrobni spomenici Bosne i Hercegovine, VI., Zemaljski muzej u Sarajevu, Sarajevo, 1954., str. 5-6, 45; G. Novović - M. Tomasović, nav. dj., str. 84. 


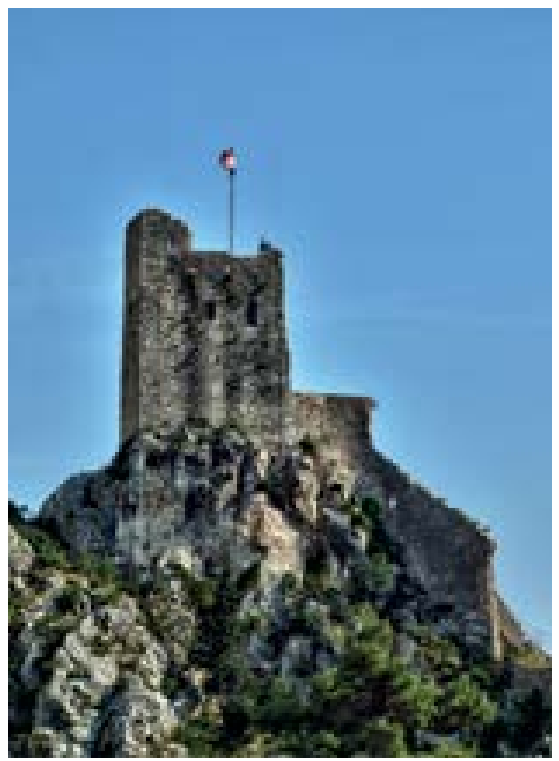

S1. 28. Utvrda Peovica u Omišu (foto: Miroslav Tomasović)

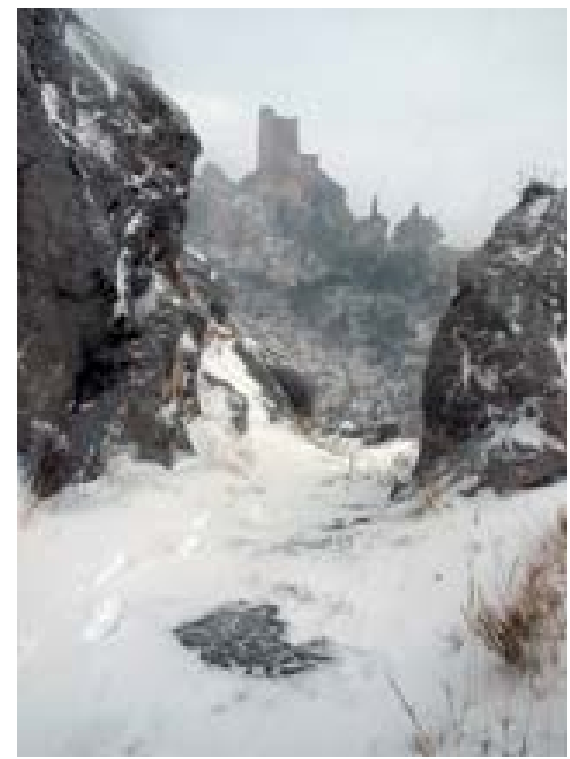

S1. 29. Utvrda Peovica u Omišu (foto: Miroslav Tomasović)

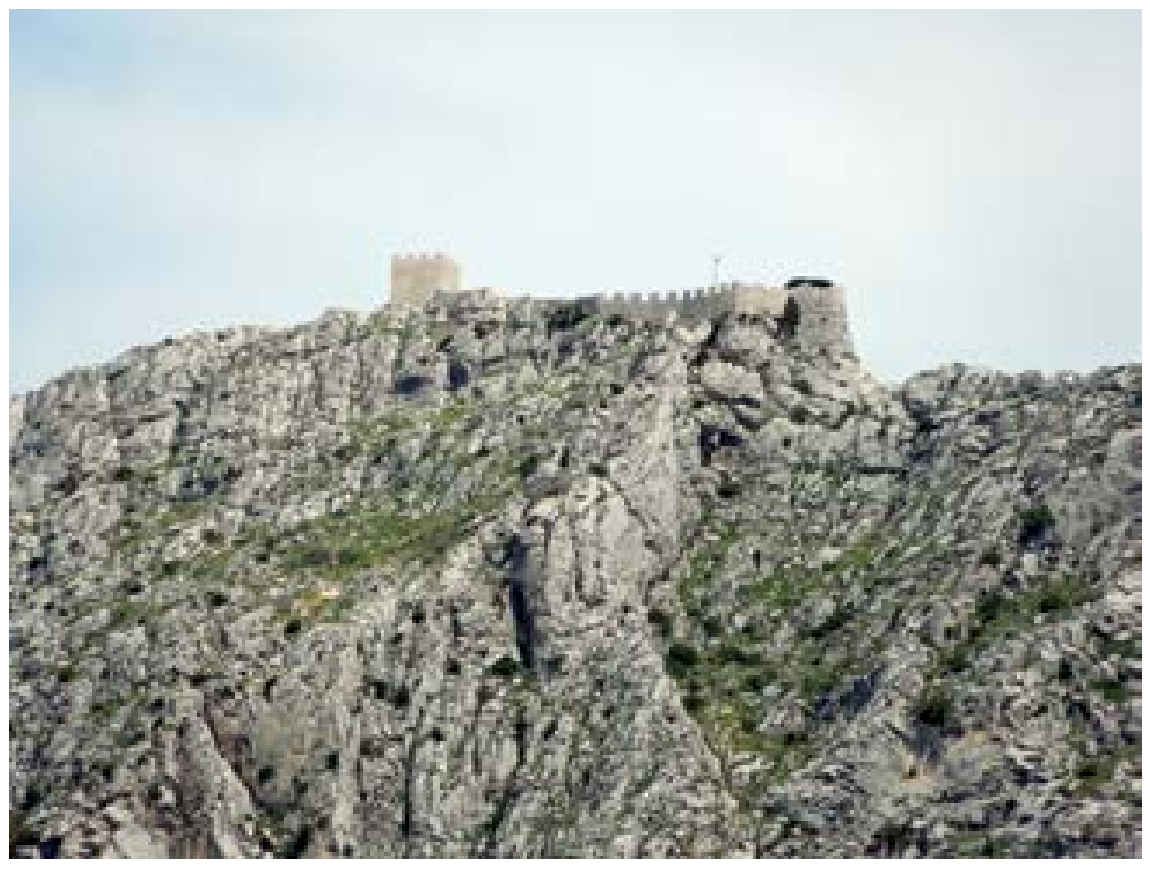

Sl. 30. Utvrda Starigrad iznad Omiša

(foto: Marinko Tomasović) 
tiqua) podignuta je krajem 14. st. ili u prvoj polovici 15. st. ${ }^{67} \mathrm{Njezi-}$ no jezgro proširivano je već u idućim desetljećima, a potvrdu skore obnove Starigrada imamo u nalazu grba mletačkog dužda Nicola Marcella (1473.-1474.) na tvrđavi. ${ }^{68}$ Starigrad se spominje 1443. u vezi s hercegom Stjepanom, ali i 1448. i 1454. kada tvrđavu drži u rukama. ${ }^{69}$ Ipak, teško je ukazivati na kakve veće graditeljske intervencije na njoj koje je poduzeo Stjepan Vukčić Kosača tijekom vladavine Omišom. Vjerojatno je tvrđavu tek obnovio nakon oštećenja prilikom osvajanja grada, kao i Peovicu u kojoj je navodno imao rezidenciju. Slično se može reći i za preostale srednjovjekovne utvrde uz donji tok Cetine, na kojima je danas teško raspoznavati slijed graditeljskih faza. Među njima je najstarija, ujedno i najznačajnija utvrda Visuć, sagrađena na teško pristupačnoj klisuri samo nekoliko kilometara uzvodno od Omiša (slika 31). ${ }^{70}$ Visuć se spominje još 1324. kao vlasništvo bosanskoga bana Stjepana II. Kotromanića, ${ }^{71}$ a potom i u povelji istoga vladara 1351. godine. ${ }^{72}$ Spominje se kasnije u povelji kralja Sigismunda 1412. i listini kninskoga kaptola 1434. kao posjed

67 Vanja Kovačić, "Omiška tvrđava Starigrad", u: Prilozi povijesti umjetnosti u Dalmaciji, 25, Split, 1985., str. 162.; VAnja Kovačıć, "Tvrđave na donjoj Cetini u obrani omiškog komunalnog teritorija", u: Omiški ljetopis, 1, Omiš, 2002., str. 75.

68 V. Kovačıć, "Tvrđave na donjoj Cetini u obrani omiškog komunalnog teritorija", str. 78. Korjenitu izmjenu, u vizuri kakvu danas poznajemo, doživljava tijekom 16.-17. st.: V. KovAčić, "Tvrđave na donjoj Cetini u obrani omiškog komunalnog teritorija", str. 79; IvAN Alduk, Srednjovjekovne tvrđave uz rijeku Cetinu, Zagreb - Split, 2010., str. 127-130.

69 Marko Vego, Naselja bosanske srednjovjekovne države, Svjetlost, Sarajevo, 1957., str. 109.

70 Netočno se stoga piše kako je tvrđava Visuć na istoimenoj planini: M. VEGo, Naselja bosanske srednjovjekovne države, str. 126, jer je na uzdignutoj klisuri sjevernog izdanka omiške planine Dinare okrenute donjem toku Cetine.

71 Prvi spomen Visuća 1324. neodređeno se vezuje za bana Stjepana Kotromanića (kojeg?), netočnim pozivanjem na vrijeme kasnijih borbi s Nelipićiama (1337.-1340.): V. Kovačić, "Tvrđave na donjoj Cetini u obrani omiškog komunalnog teritorija", str. 82. Neprikladno je pri tome i referiranje na: M. VEGO, Naselja bosanske srednjovjekovne države, str. 126, gdje se prvi spomen Visuća sagledava kroz povelju bosanskoga bana Stjepana II. Kotromanića iz 1351.

72 M. VEGo, Naselja bosanske srednjovjekovne države, str. 126. 


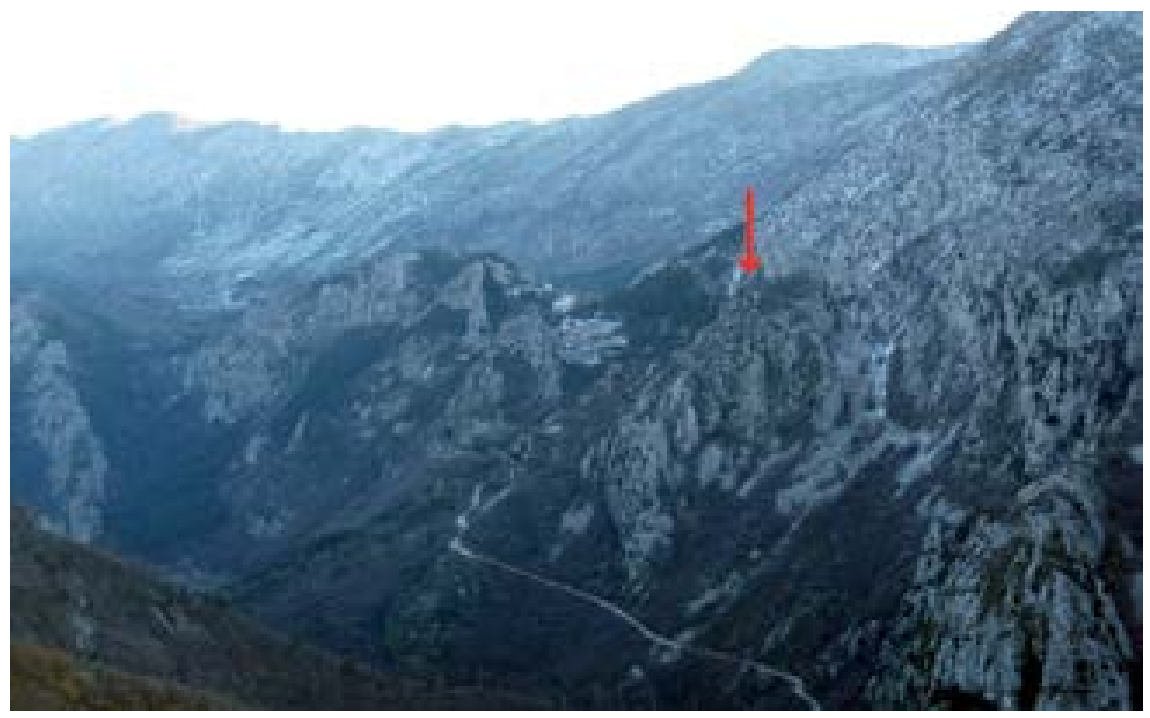

S1. 31. Položaj utvrde Visuć iznad Cetine kod sela Svinišće pogledom iz Poljica (foto: Marinko Tomasović)

Nelipića. ${ }^{73}$ Položaj kao granična točka suprotne strane Cetine spominje se u dopunjenom Poljičkom statutu iz $1482 .{ }^{74}$ Podno Visuća, u Podviseću gdje se naplaćivala carina, herceg Stjepan namjeravao je 1457. preko Cetine sagraditi most, ali ga Venecija odvraća od toga nauma. ${ }^{75}$ Visuć je 1473. zauzeo Stjepanov sin herceg Vlatko, ${ }^{76}$ iako

73 Radoslav Lopašıć, "Cetinski i lički Vlasi" u: Ivan Mužıć (prir.), Vlasi u starijoj hrvatskoj historiografiji, Muzej hrvatskih arheoloških spomenika, Split, 2010., str. 22.

74 Alfons Pavić, "Prinosi povijesti Poljica", u: Glasnik Zemaljskog muzeja u Bosni i Hercegovini, XV./1, Sarajevo, 1903., str. 28; Ivan BanIć (prir.), Poljički statut, Gata, 1995., str. 9.

75 Miroslav Vulić, "Herceg Stipan", u: Poljica, List Poljičkog dekanata, IX./1(9), Gata, 1984., str. 45. Carine pod Visućem (et gabellas subtus Visech(es)ium) spominju se u povelji kralja Ostoje 1408. kojom se braći Radivojevićima daje u posjed zemlja između Neretve i Cetine: Ferdo ŠIšić, "Nekoliko isprava iz početka XV st.", u: Starine Jugoslavenske akademije znanosti i umjetnosti, knj. XXXIX., Zagreb, 1938., str. 316; PAVAo AnĐElić, "Srednjovjekovna župa Večenike (Večerić) i postanak Mostara", u: Pavao AnĐelić - Marijan Sivrić - Tomislav AnĐelić, Srednjovjekovne humske župe, Ziral, Mostar, 1999., str. 167.

76 M. VEgo, Naselja bosanske srednjovjekovne države, str. 127; I. Božıć, nav. dj., str. 116; A. PAPONJA, "Prostor donje Neretve u vojno-obrambenoj strategiji kralja Matijaša Korvina (1458-1490)", str. 53, bilj. 53. 
se vjerojatno radilo o privremenom gubitku utvrde koja je još 1466 . bila u nadležnosti Stjepana Kosače. ${ }^{77}$ Utvrdu je predao Mlečanima 1478. kako bi se lakše obranila od Osmanlija. ${ }^{78}$ Stoga Mlečani na Visuću 1481. i 1488. poduzimaju opsežne graditeljske radove, dok popis naoružanja utvrde govori o njezinoj iznimnoj ulozi u strategijskom otporu nadolazećim Osmanlijama. ${ }^{79}$

Danas je nemoguće naznačiti opseg i izgled tvrđave u vrijeme hercega Stjepana Kosače, osobito što se ostatci njezinih zidova jedva razaznaju. Visuć je kao već postojeću utvrdu zacijelo mogao tek neznatno obnoviti. Glavnina graditeljskih radova na utvrdi pripada vremenu nakon njegove smrti, sve do kraja 16. st., jer od druge polovice 17. st. Visuć gubi svoju ulogu. ${ }^{80} \mathrm{Za}$ vrijeme hercega Stjepana još teže je dokazivati postojanje, nekoliko kilometara uzvodnije, ranije jezgre utvrde na položaju Kunjak u Kučićima, zasnovane na mjestu prapovijesne gradine.$^{81} \mathrm{Njezino} \mathrm{podizanje} \mathrm{vezuje} \mathrm{se} \mathrm{za} \mathrm{graditeljsku} \mathrm{ak-}$ tivnost Žarka Dražojevića, negdje 1473.-1479., iako se u prilog tome nisu iznijele potvrde. ${ }^{82}$ Kunjak je, sudeći prema izostanku učestalih spomena u izvorima, zastalno imao kratkotrajniju ulogu. Najvjerojatnije da je i porušen u ranom nasrtaju Osmanlija, do $1492 .{ }^{83}$ iako se tek 1669. govori o ruševnom stanju utvrde. ${ }^{84}$ Uostalom, to je i ra-

77 A. Paponja, "Prostor donje Neretve u vojno-obrambenoj strategiji kralja Matijaša Korvina (1458-1490)", str. 53, bilj. 53. Mlečani se u godini smrti hercega Stjepana 1466. obvezuju naoružati i braniti njegovu utvrdu Visuć: V. Kovačıć, "Tvrđave na donjoj Cetini u obrani omiškog komunalnog teritorija", str. 82, bilj. 24.

78 V. Kovačić, "Tvrđave na donjoj Cetini u obrani omiškog komunalnog teritorija", str. 82.

79 Isto, str. 83-84.

80 Isto, str. 84-85.

81 M. Tomasović, "Arheološka topografija lijeve strane donjeg toka Cetine", str. 234-235.

82 Tvrdnju je iznio: Tomislav Heres, "Poljički knez Žarko Dražoević u povijesti i književnosti", u: Poljica, List Poljičkog dekanata, IX./1(9), Gata, 1984., str. 37; I. Alduk, Srednjovjekovne tvrđave uz rijeku Cetinu, str. 111, dopušta takvu mogućnost. S druge strane netočno se govori o spomenu Kunjaka u poljičkom Statutu 1482.: V. Kovačıć, "Tvrđave na donjoj Cetini u obrani omiškog komunalnog teritorija", str. 85; V. Kovačıć, "Urbanistički razvitak i arhitektura", u: ŽArko Domljan (prir.), Omiš i Poljica, Zagreb, 2006., str. 240.

83 T. Heres, "Poljički knez Žarko Dražoević u povijesti i književnosti", str. 37.

84 V. Kovačıć, "Tvrđave na donjoj Cetini u obrani omiškog komunalnog teritorija", str. 85 , bilj. 30 . 
zumljivo u pogledu zamiranja dominantnijega Visućana zapadu, a s kojim je Kunjak bio u vizualnoj povezanosti.

Također ni tvrđavi Duare (Zadvarje), izravno spomenutoj ("pod grad Zadvarje") 1482. kao međašu Poljica, ${ }^{85}$ nije moguće utvrditi raniju jezgru u vremenu hercega Stjepana. Iznijet je prijedlog kako tvrđava $u$ njegovo vrijeme nije ni postojala, odnosno sagrađena je od posljednje godine njegova života, negdje 1466.-1482., moguće i od 1478.-1482. ${ }^{86}$ Ipak, s pravom se dopušta mogućnost postojanja manje utvrde oko 1408., na istom mjestu gdje se kontinuirano nadograđivala sve do kraja 17. st. ${ }^{87}$ Ona je podrazumljiva i u pogledu spomena mjesta 1408. (...locum Duarum cum provincia Radobilie...) u povelji kralja Ostoje. ${ }^{88}$ Duare su nesumnjivo u posjedu hercega Stjepana 1440. kada osvaja Omiš i Poljica, ${ }^{89}$ a moguće i istoimena utvrda. Ipak, prostor Duara s Radobiljom predstavlja jedino pouzdano očitovanje graditeljske poduzetnosti hercega Stjepana na donjem toku Cetine. Ona se u prvom redu odnosi na njegovu namjeru gradnje ili korjenitoga adaptiranja jedne već postojeće utvrde u Radobilji i gradnje mosta preko Cetine za lakši pristup Poljicima. ${ }^{90}$ Po svemu sudeći do gradnje utvrde je i došlo, ali nije poznat njezin položaj. ${ }^{91}$ Mletačka

85 I. BANić (prir.), Poljički statut, str. 9.

86 IvAn Alduk, "Uvod u istraživanje srednjovjekovne tvrđave Zadvarje (1. dio - do turskog osvajanja)", u: Starohrvatska prosvjeta, III. s., 35, Split, 2005., str. 225. Očitom omaškom 1478. uzima se kao godina preuzimanja Visuća od strane hercega Vlatka, jer tada ovu utvrdu predaje Mlečanima.

87 I. Alduk, "Uvod u istraživanje srednjovjekovne tvrđave Zadvarje (1. dio - do turskog osvajanja)", str. 224, 226.

88 F. ŠIšıć, nav. dj., str. 316; P. ANĐELIĆ, nav. dj., str. 167.

89 I. Alduk, "Uvod u istraživanje srednjovjekovne tvrđave Zadvarje (1. dio - do turskog osvajanja)", str. 223.

90 V. Kovačıć, "Tvrđave na donjoj Cetini u obrani omiškog komunalnog teritorija", str. 86. Kod opetovanja navoda spominje Mandušića kulu u Katunima, čime neizravno sugerira kako je herceg Stjepan vjerojatno na njenom mjestu namjeravao (ili započeo) graditi utvrdu: VANJA Kovačıć, "Urbanistički razvitak i arhitektura", str. 241; I. ALDuk, Srednjovjekovne tvrđave uz rijeku Cetinu, str. 102, za položaj hercegove utvrde veli kako se nalazila "negdje u Radobilji".

91 I. Alduk, "Uvod u istraživanje srednjovjekovne tvrđave Zadvarje (1. dio - do turskog osvajanja)", str. 224, gdje se napominje kako nije jasno radi li se o jednoj ili dvije utvrde. Navodi položaje uz rijeku na kojima je herceg mogao podići tvrđavu: Blato na Cetini, te nizvodnije Kreševo i Golu glavu južno od župne crkve u Katunima. Auktor, možda i nepotrebno, isključuje mogućnost 
vlada 1457. i 1458. traži od Hercega da spornu tvrđavu poruši, ali ona ostaje netaknuta. ${ }^{92}$

Ranije podignut Vrgorac, u Gorskoj župi, u izvorima 1444.-1445. i 1448. navodi se kao posjed hercega Stjepana. ${ }^{93}$ Do 1470 . u posjedu je hercega Vlatka, kada mu ga oduzimaju braća Vlatkovići. ${ }^{94}$ Prema kasnijem crtežu u podnožju tvrđave bio je podignut gradski bedem $\mathrm{s}$ karakterističnim srednjovjekovnim elementom gibelinskog, zupčastog kruništa i kulama sa strane. ${ }^{95}$ Prema izvještaju mletačkog vojnog inženjera I. F. Rossinija iz 1749., koji navodi i kruništa, razvidno je kako su tada još sačuvani dijelovi srednjovjekovne utvrde. ${ }^{96}$

Herceg Stjepan Kosača u onodobnim pisanim izvorima povezuje se i za grad Vratar na desnoj strani Neretve (slike 32-33). Značenje utvrde, spomenute 1434., opisom i kroz izvore najuspješnije je prikazao R. Dodig, naznačivši 1444.-1466. kada se Vratar redovito spominje s

kako se radilo o proširenju već tada postojeće tvrđave Duare, osobito što je prethodno dopustio mogućnost kako se radilo i o gradnji dvaju utvrda: str. $224,226$.

92 U literaturi se ne razaznaje uvijek što Mlečani 1457. zahtijevaju od hercega Stjepana. V. Kovačıć, "Tvrđave na donjoj Cetini u obrani omiškog komunalnog teritorija", str. 86, piše kako je herceg Stjepan tek naumio sagraditi utvrdu i most u Radobilji. Za protivljenje Venecije takvoj inicijativi, u strahu da gradnje u konačnici ne posluže Osmanlijama za pristup Poljicima, netočno referira Božićev rad u kojemu se govori o događajima iz 1471. kada je glavnu ulogu imao herceg Vlatko: I. BožIć, nav. dj., str. 119. Pak, Josıp AnTE Soldo, Župa Radobilja (Katuni-Kreševo), Omiš, 1970., str. 12, ne pozivajući se na izvore, govori o započetoj gradnji tvrđave, a zahtjev Mlečana stavlja u 1455. Navodno, unatoč traženja Venecije 1455. da odustane od tih planova, herceg Stjepan započinje graditi utvrdu i most. Moguće su porušeni ili oštećeni od strane Splićana, jer Senat na hercegovu pritužbu 1457. obećava kako će splitski knez nadoknaditi štetu. Na datom mjestu Soldo spominje neimenovanu tvrđavu 1462., ali u jasnoj kontekstualizaciji kao sporne hercegove gradnje. Teritorij župe Radobilje u posjedu je Kosača i nakon smrti hercega Stjepana, jer Venecija 1467. potvrđuje ranija prava njegovom sinu i nasljedniku hercegu Vlatku: A. PAPONJA, "Prostor donje Neretve u vojno-obrambenoj strategiji kralja Matijaša Korvina (1458-1490)", str. 53, bilj. 53.

93 M. Vego, Naselja bosanske srednjovjekovne države, str. 135.

94 I. Božıć, nav. dj., str. 119; A. Paponja, "Prostor donje Neretve u vojnoobrambenoj strategiji kralja Matijaša Korvina (1458-1490)", str. 53, bilj. 53.

95 Cvito Fisković, "Najstariji opisi i slike Vrgorca", u: Bulletin Zavoda za likovne umjetnosti JAZU, IX./3, Zagreb, 1961., str. 128-129.

96 C. Fisković, "Najstariji opisi i slike Vrgorca", str. 125. 
MARINKO TOMASOVIĆ - GOTIČKA UMJETNOST U PRIMORJU...

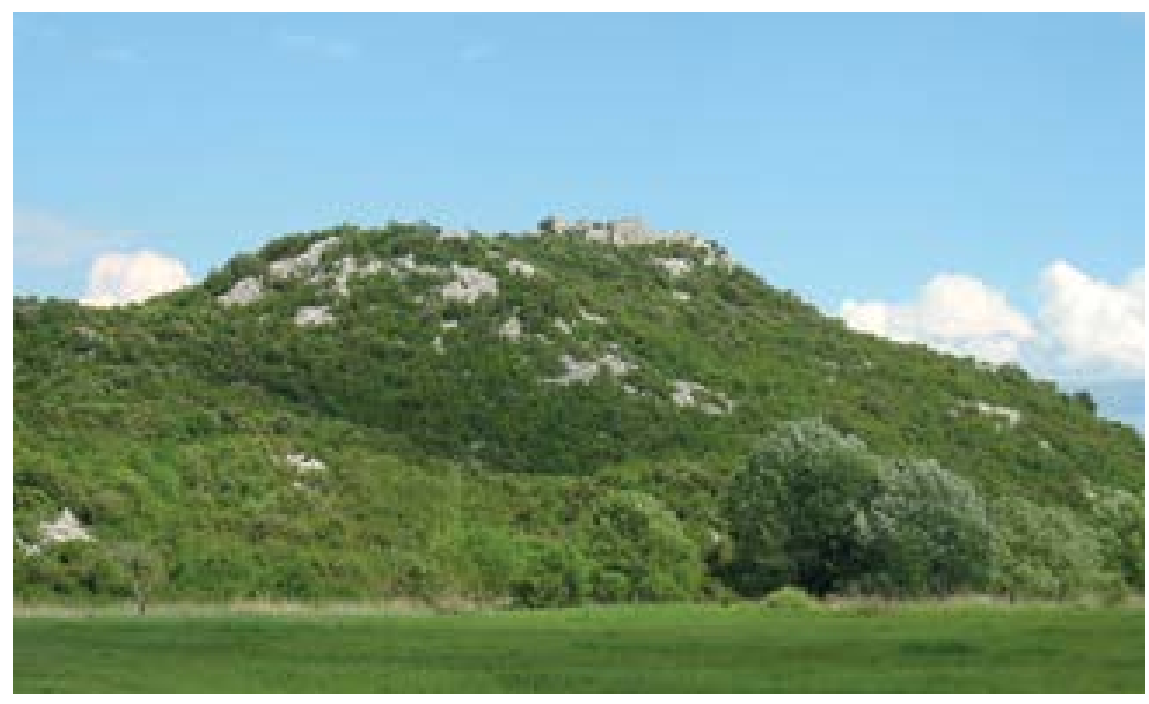

S1. 32. Položaj utvrde Vratar kod Borovaca (foto: Marinko Tomasović)

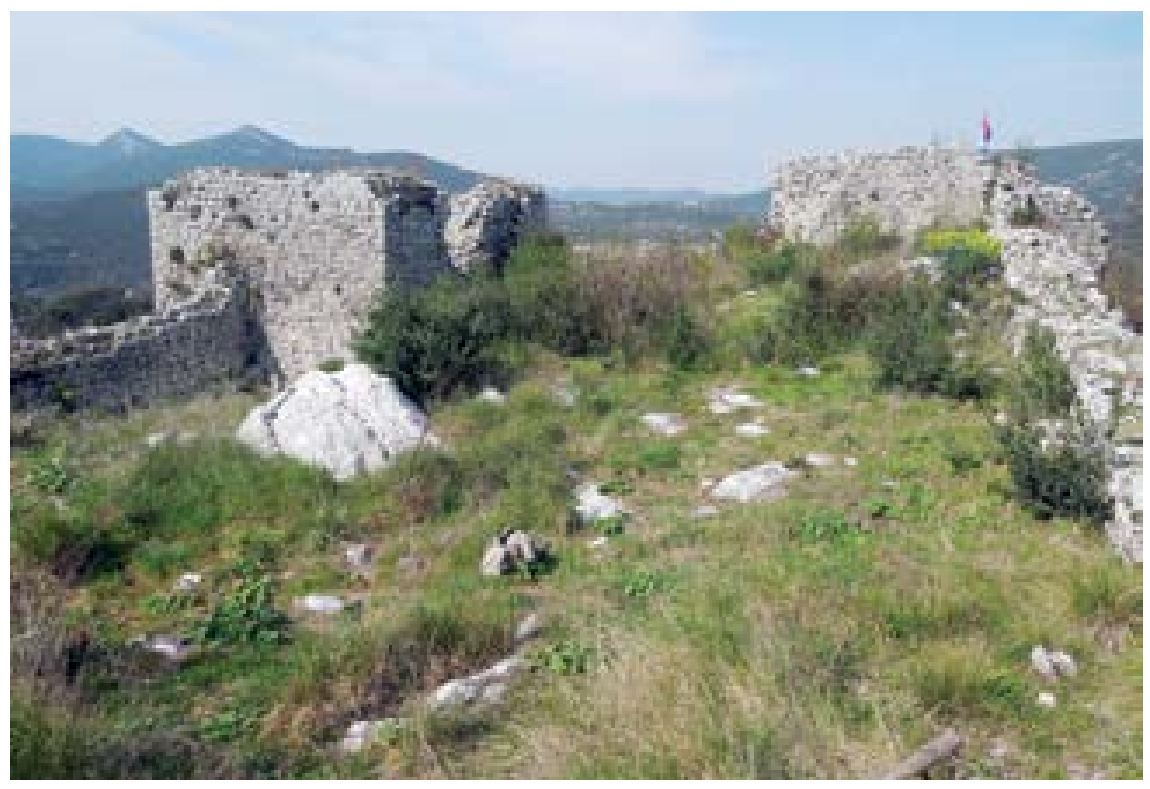

Sl. 33. Utvrda Vratar kod Borovaca (foto: Marinko Tomasović) 
imenom hercega Stjepana Kosače.$^{97}$ Kako se njegovo podizanje pretpostavilo krajem 14. st., a pad u ruke Osmanlija 1472., godinu nakon Počitelja, ${ }^{98}$ radilo bi se o tek manje opsežnim zahvatima na Vrataru u samom trajanju hercegove vlasti nad njim 1444.-1454. ${ }^{99} \mathrm{U}$ rukama hercega Stjepana bila je i utvrda Brštanik kod Opuzena, značajna u ratu s Dubrovčanima 1451.-1454. ${ }^{100}$ Dubrovčani ga preuzimaju navodno još 1450., kada ruše i hercegovu utvrdu na Osinju na samom ušću Neretve, a 1452. šalju pomoć hercegovu sinu Vladislavu. ${ }^{101} \mathrm{Mo}-$ guće je da su Brštanik 1472. i porušili Dubrovčani, kada spaljuju i Posrednicu na mjestu današnjeg Opuzena. ${ }^{102}$ Drugdje se veli, iako

97 Radoslav Dodig, "Grad Vratar i njegovi gospodari", u: Dubrovnik, N. s., IX./4, Dubrovnik, 1998., str. 71-80.

98 R. Dodig, "Grad Vratar i njegovi gospodari", str. 80.

99 M. VEGo, Naselja bosanske srednjovjekovne države, str. 134.

100 A. Paponja, "Prostor donje Neretve u vojno-obrambenoj strategiji kralja Matijaša Korvina (1458-1490)", str. 57, bilj. 66.

101 Tvrđavu na Osinju navode dubrovački izvori 1422. i 1426.: M. VEGo, Naselja bosanske srednjovjekovne države, str. 87; Minailo Dinić, "Trg Drijeva u srednjem veku" (ćirilica), u: Godišnjica Nikole Čupića, XLVII., Beograd, 1938., str. 140, sa sigurnošću govori o Osinju kao položaju na kojemu splitski knez J. Marcelo 1465., nakon što je zagospodario Primorjem i Drijevima, dobio odobrenje za gradnju utvrde. Nije poznato je li se započelo s njenom gradnjom, točnije obnovom. Sudeći prema kasnijim izvorima utvrdu na Osinju, ušću Neretve, podigli su 1471.-1472. Dubrovčani, čime su najizravnijim nadzorom ulaza u rijeku nastojali nadoknaditi gubitak Posrednice: A. PAPONJA, "Prostor donje Neretve u vojno-obrambenoj strategiji kralja Matijaša Korvina (1458-1490)", str. 65.

102 Rade Jerković, "Dvije stare tvrđave na ušću Neretve (Brštanik i Koš)", u: Kalendar Napredak, p.o., Sarajevo, 1941., str. 11. U novijoj literaturi, pozivanjem na Jerkovića, pretpostavlja se kako je tada porušen tek Brštanik: Đ. TošIć, "Brštanik u srednjem vijeku", str. 49. Tošićevu referencu o rušenju Brštanika 1472. preuzima: R. DodIG, "Grad Vratar i njegovi gospodari", str. 80. Spaljivanje Posrednice od strane Dubrovčana 1472. nije značilo kako je položaj od tada napušten, jer se na tom mjestu i dalje nalazi utvrda kralja Matije Korvina, često spominjana u dubrovačkim izvorima 1481.-1491. kao Koš (fortezza Koso ovvero Opusena). Navodno ju je kralj, uz suglasnost Dubrovčana, i podigao oko 1463., te obnovio nakon spaljivanja Dubrovčana. Čini se uvjerljivijim kako je već 1490.-1491. osvojena od Osmanlija: A. PAPONJA, "Prostor donje Neretve u vojno-obrambenoj strategiji kralja Matijaša Korvina (1458-1490)", str. 73, nego 1500. kako piše: M. Sivrić, nav. dj., str. 383, pozivajući se na Jerkovića. Pak, drugdje se veli kako su Dubrovčani 1472. podigli utvrđenje na Posrednici nakon pada Počitelja u ruke Osmanlija, ali ga iste godine i spalili nakon pritužbe hercega Vlatka Porti: I. Božıć, nav. 
pozivanjem na stariju literaturu, kako je utvrda Brštanik porušena od Osmanlija prije $1483 .{ }^{103}$

\section{Izmedu predaje i stvarnosti: manje poznate utvrde Hercegova kula i Ercegova gradina u Primorju}

U Primorju su poznata dva položaja s gradnjama koje nose naziv Hercegova kula i Ercegova gradina, a o kojima se ništa ne doznaje iz pisanih izvora. Tek su spomenute u literaturi kao indikativni toponimi, dokazi gradnje hercega Stjepana. ${ }^{104}$ Hercegova kula, ili Kula hercega Stipana, u Gornjim Brelima nalazi se oko $300 \mathrm{~m}$ istočnije od zapuštenoga zaseoka Sokoli (slike 34-36). Pregledno sagledavanje spomeničke baštine uključilo ju je u krug gradnji kojima se pouzdano ne razaznaje vrijeme nastanka, iako uključuje i 15 . st. ${ }^{105}$ Gradnja predstavlja solidno zidani dvokatni kaštel adaptiran uz abrij litice, veličine $3 \times 5 \mathrm{~m}$ u prizemlju, odnosno 2,4 $\mathrm{m}$ širine prostora od stijene do nasuprotnog dužeg jugozapadnog zida. $S$ te strane se i ulazilo na prvi kat kaštela, dok je manji ulaz vjerojatno vodio u prizemlje s istoka, na mjestu porušenog zida debljine $0,63 \mathrm{~m}$. Pravokutnim tlocrtom donekle upućuje na kasni srednji vijek, iako se na njemu ne očituju izrazite stilske karakteristike toga vremena. I uz litice zapadno od kaštela nalaze se ostatci, moguće kasnijih, suhozidnih gradnji.

dj., str. 121, bilj. 38. Na temelju navedenog ne čini se stoga pouzdanim Hrabakovo pozivanje na Klaića o tobožnjoj želji kralja Matije Korvina da 1488. ponovo podigne porušenu utvrdu Koš, osobito što nazočnost njegove vojske i nabavke prije potvrđuju kako se radi o njenoj obnovi u smislu održavanja ili ojačanja: Bogumil Hrabak, "Uskočke akcije krajišnika na ušću Neretve (1482-1537)", u: Historijski zbornik, XXIX.-XXX., 1976.-1977., Zagreb, 1977., str. 182.

103 R. Jerković, "Dvije stare tvrđave na ušću Neretve (Brštanik i Koš)", str. 12. Ostaje nepoznat uži položaj utvrde (možda i sustava utvrda) u Desnama s desne strane Neretve, čiji se kaštelan spominje u dubrovačkim izvorima 14. i početka 15. st. Za prijedlog njezine približne ubikacije vidi: M. Tomasović, "Arheološka i povijesna topografija Desana", str. 237-238.

104 K. JuRIŠIĆ, "Stariji hrvatski natpisi Makarskoga primorja (XV-XVIII st.)", str. 122.

105 Spomenuta je u pogledu toponima kao lokalitet koji "možda čuva uspomenu na bosanskog velikaša i hercega Stipana Vukčića Kosaču...": Ivan Alduk - Marinko Tomasović, "Sakralna arhitektura i ostali kulturno-povijesni spomenici na području Biokova", u: Roman Ozimec (prir.), Biokovo, Graphis - Park prirode Biokovo, Zagreb, 2008., str. 167. 


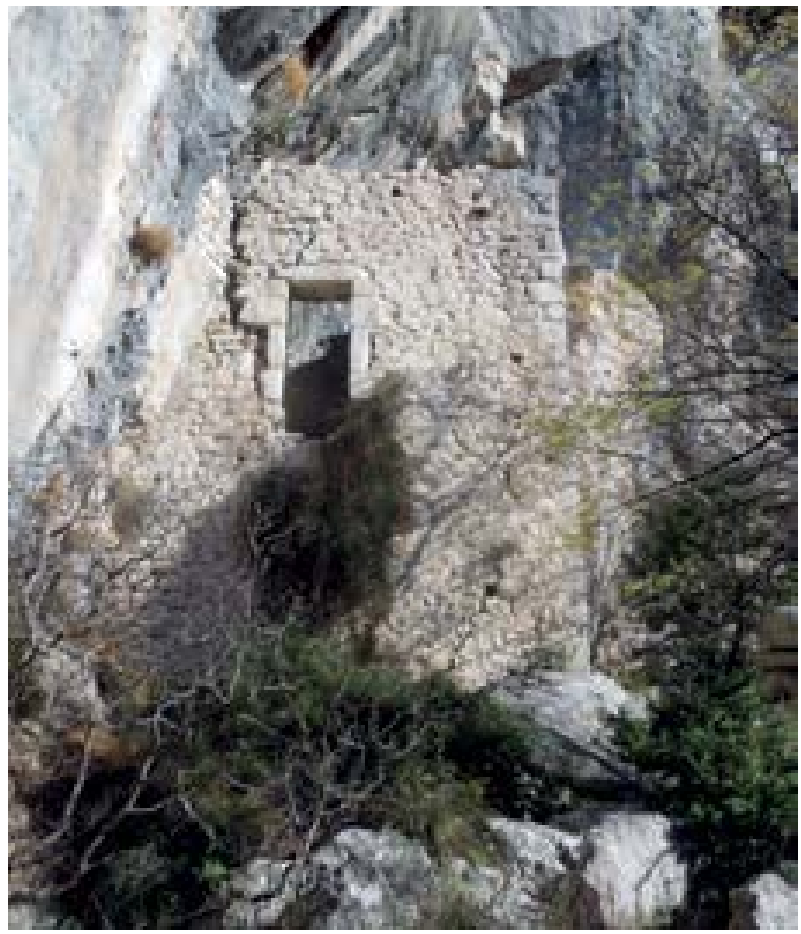

Sl. 34. Ulazna strana Hercegove kule (Kula hercega Stipana) u Gornjim Brelima (foto: Marinko Tomasović)

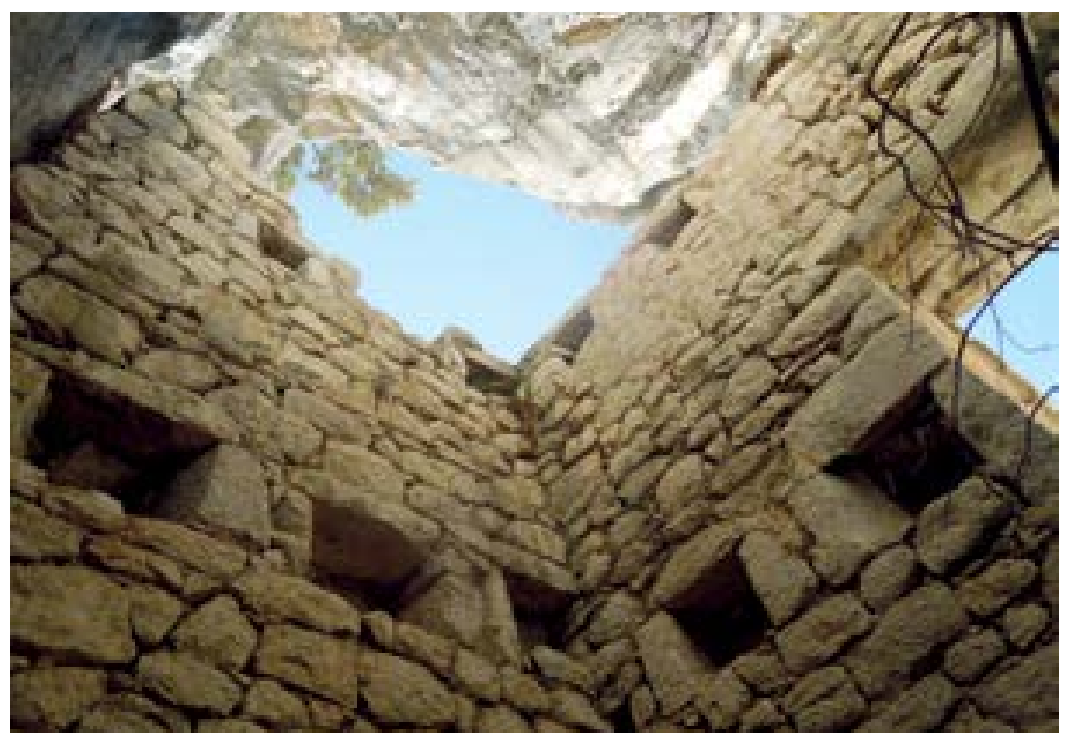

Sl. 35. Unutrašnjost Hercegove kule (Kula hercega Stipana) u Gornjim Brelima (foto: Marinko Tomasović) 


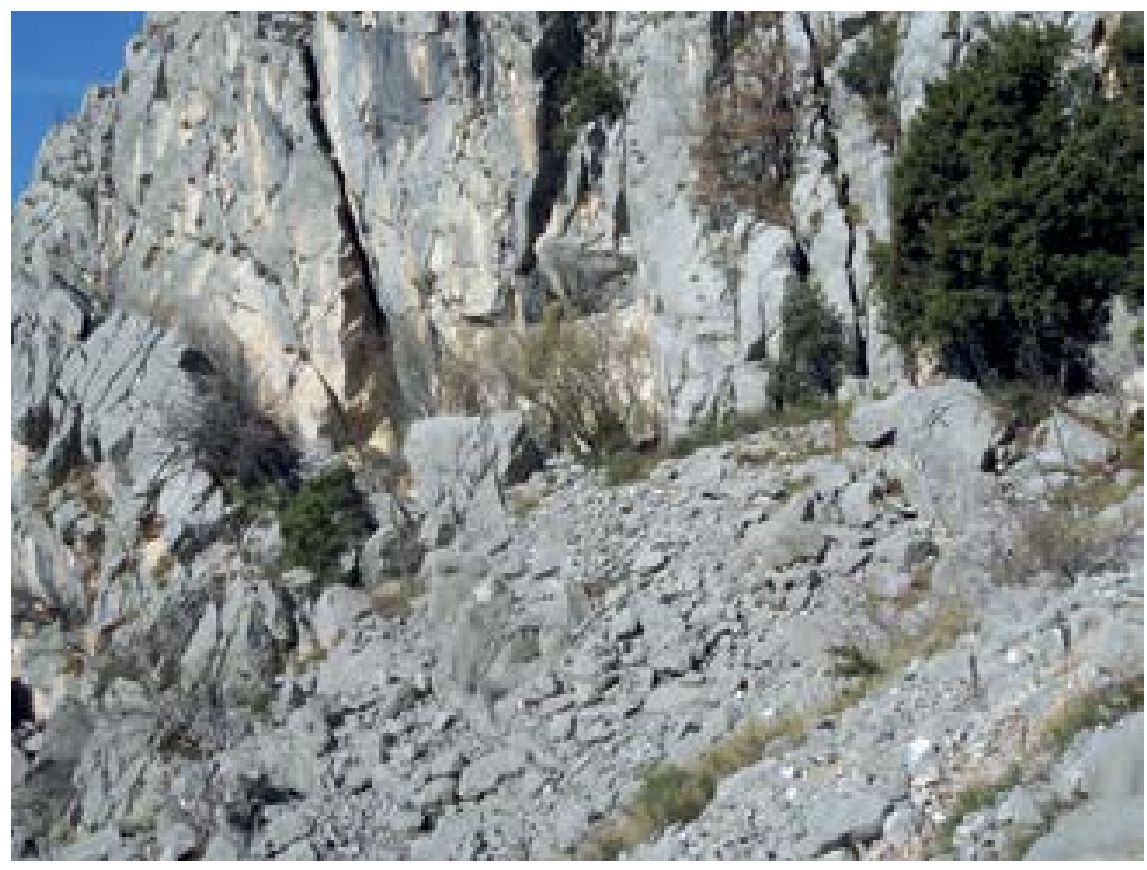

S1. 36. Položaj Hercegove kule (Kula hercega Stipana) u Gornjim Brelima

(foto: Marinko Tomasović)

Za sada je dopušteno tek iznijeti neke primjedbe u pogledu moguće datacije kaštela kao kasnosrednjovjekovnoga. Apstrahira li se izostanak osjetljivih stilskih pokazatelja na gradnji, osim tlocrta koji je možda i rezultat prilagodbe terena i nevelikog prostora, za pripadnost 15. st. (neovisno, hercegu Stjepanu ili nasljednicima) upućuje spomenička kontekstualizacija užeg prostora. Zapadnije od Sokola podignuta je na uzvisini u 14.-15. st. gotička crkva sv. Nikole, uokolo koje su nadgrobne ploče, ${ }^{106}$ čime je obuhvaćen i vremenski okvir vlasti hercega Stjepana na ovome prostoru. Međutim, vrijednost ovoga dijela terena je i u pogledu iznimnoga strateškog značaja uokolo crkve sv. Nikole, zbog čega se i iznio prijedlog ubiciranja Berulije iz 10. st., poznate iz djela bizantskog cara Konstantina Porfirogeneta. ${ }^{107} \mathrm{~S}$

106 M. Tomasović, Srednjovjekovni nadgrobni spomenici u Makarskom primorju, str. 21-23, 81-83, T. I, 2; M. TomAsović, "Toponomastika i hagiotoponomastika kroz arheološke indicije za obalni pojas između donjeg toka Cetine i Neretve", str. 125.

107 Marinko Tomasović, "Arheološke sugestije za ubikaciju gradova iz 36. poglavlja Porfirogenetova De administrando imperio", u: Starohrvatska prosvjeta, III. s., 36, Split, 2009., str. 305-307. 
položaja crkve, ranije prapovijesne nadzorne točke, izvrsno se gleda komunikacijski prijevoj ka moru, a osobito širi pojas Radobilje i tvrđave Duare na sjeverozapadu. Takve vrijednosti izostaju na položaju Hercegove kule, koja je posve zaklonjena i bez mogućnosti nadzora iole bitnijih pravaca i šireg pristupnog terena. ${ }^{108}$ Ovim prije govori kako je podignuta kao kaštel refugijalnog značaja, osobito što je dobro skrivena u blizini naselja. Teško je vjerovati kako bi se vladari, osobito u posve nemirnom i politički prevrtljivom vremenu sredine 15. st., odlučili za podizanje manje utvrde na tako pasivnom položaju kakvog ima Hercegova kula. Uostalom, na refugijalne važnosti kaštela s puškarnicama upućuju i suhozidine zapadnije od nje, najvjerojatnije gospodarskoga karaktera. Stoga naziv položaja u planinskom predjelu Brela, što će se donekle sličnim determiniranjem kasnije objasniti u slučaju kasnoantičke eremitaže i mletačkoga grba u Omišu, primarno odražava značaj hercega Stjepana Kosače. Uostalom, riječ je o kraju s trajnijom hercegovom vlašću, s Radobiljom u susjedstvu i spomenutim događajima uz rijeku Cetinu tijekom zadnjeg desetljeća njegova života. Samu pripadnost gradnje vremenu hercega Stjepana, zanemari li se sama predaja o utvrdi kao njegovoj, valja ostaviti otvorenom ili je dopustiti tek kao pretpostavku u povijesnim okvirima 15. st.

Okvirom vlasti hercega Stjepana Vukčića Kosače na ovom prostoru, od 1440. do 1466., a osobito njegova nasljednika, sina hercega Vlatka, s većom sigurnošću ipak treba sagledati podizanje Ercegove gradine na planinskom predjelu sela Veliko Brdo iznad Makarske (slike 3740). Ova nevelika pravokutna kula, dužine zidova 16 × $8 \mathrm{~m}$ i sačuvane visine do $2 \mathrm{~m}$, podignuta je na klisuri gotovo nepristupačnog izdanka masiva Biokova zapadnije od sela. Podizanje Ercegove gradine može se promotriti u okviru plana o tadašnjem utvrđivanju Makarske, čime je njezina datacija od sredine do druge polovice 15. st. gotovo neupitna. Vlatko Kosača uputio je Mlečanima 1477. zahtjev, ili podsjećanje na ranije obećanje Senata, za pomoć u utvrđivanju Makarske. ${ }^{109}$ Teško je dokazati kako se uopće započelo s ovom grad-

108 Hercegova kula podignuta je uza sipar ispod Prve vode na planinskoj oputini za uzdignuti Bukovac, isključivo planinskog, stočarskog karaktera. Komunikacija je posve izvan uloge u kakvom pristupu zabiokovskim selima u podnožju visokog biokovskog hrpta. Uz to, put se i ne nadgleda dobro s Hercegove kule u podnožju.

109 I. Božić, nav. dj., str. 123. Upadljivo je kako se Macarscha, iz izvora koji se donosi, preslobodno mijenja u Makar (selo iznad Makarske): NEven IsAILović, 


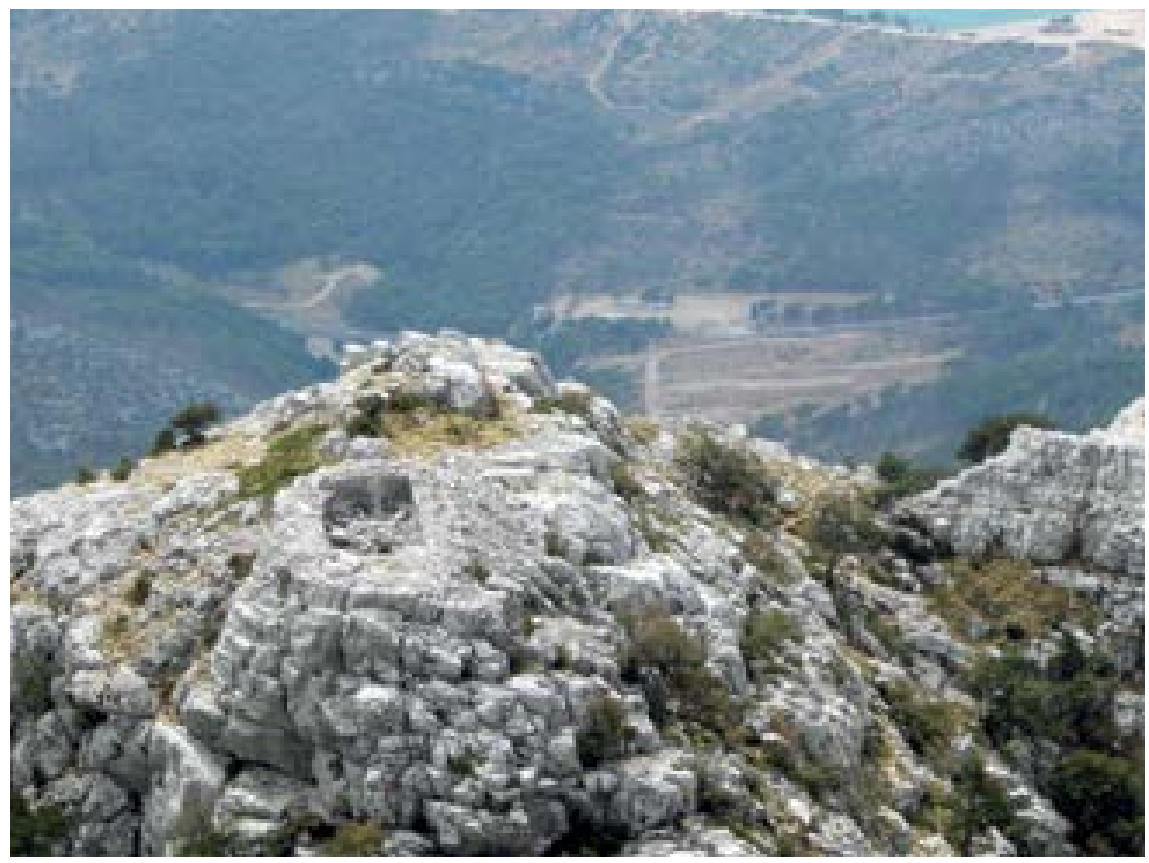

Sl. 37. Ercegova gradina na planinskom predjelu sela Veliko Brdo iznad Makarske (foto: Matko Jurčević)

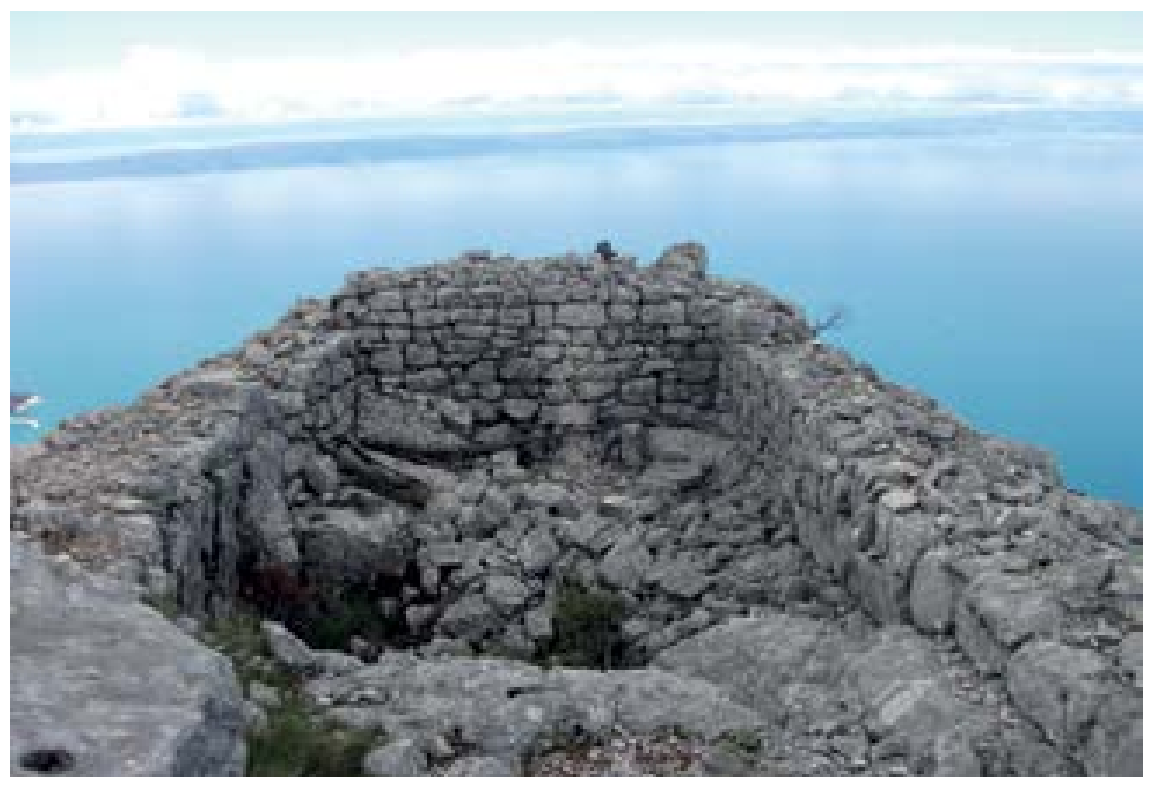

Sl. 38. Ercegova gradina na planinskom predjelu sela Veliko Brdo iznad Makarske (foto: Matko Jurčević) 


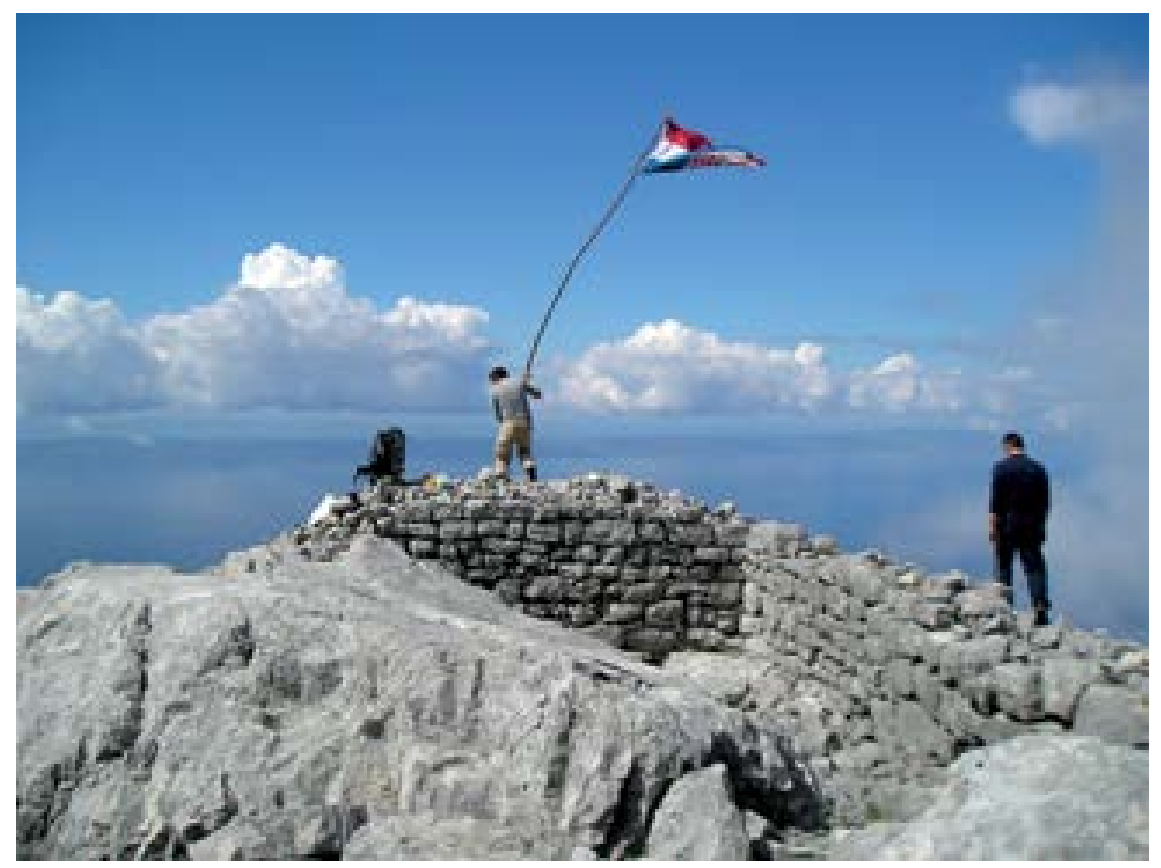

S1. 39. Ercegova gradina na planinskom predjelu sela Veliko Brdo iznad Makarske

(foto: Matko Jurčević)

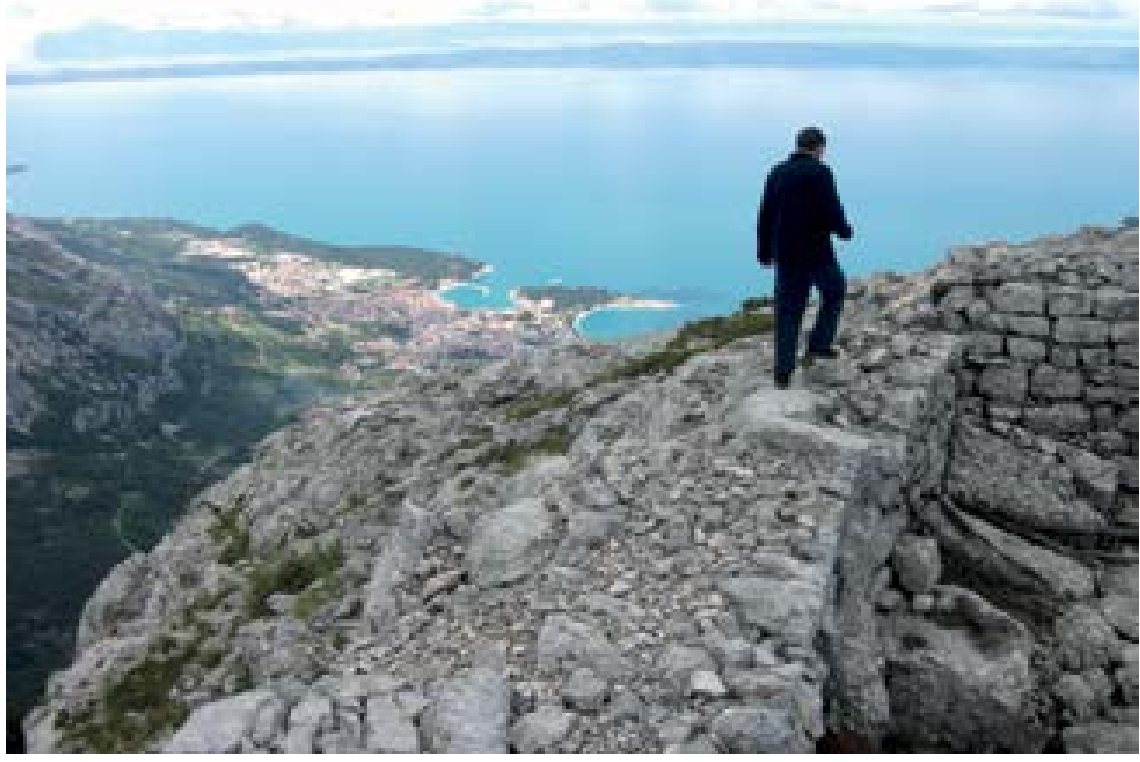

Sl. 40. Ercegova gradina i Makarska u južnom obalnom podnožju (foto: Matko Jurčević) 
njom, ${ }^{110}$ ali je razložno pomišljati o podizanju barem manje utvrde kakva je Ercegova gradina. To što se ova gradi sjevernije od grada razumljivo je u pogledu njezine iznimne mogućnosti za nadgledavanje širokog morskog i priobalnog prostora, iako nije postavljena uz pješačku komunikaciju prema planini. Obranu naseobinske jezgre uz more na sebe je mogla primiti, možda ovom prilikom obnovljena, utvrda na Sv. Petru. ${ }^{111}$ Pak, ono što dodatno upućuje na Ercegovu gradinu kao utvrdu iz sredine 15 . st. odnosi se na njezinu udaljenost od sela Veliko Brdo smještenog u biokovskom podnožju iznad Makarske. To je dokaz kako nije predstavljala refugij, kakve su zazidane pećinice i kašteli iz osmansko-venecijanskog 16.-17. st. na užem prostoru makarskih sela, Velikog Brda, Makra i Kotišine, ${ }^{112}$ nego samosvojno utvrdu koju je podigao moćni vlastodržac. Stoga, možemo s većom sigurnošću zaključiti kako Ercegova gradina uistinu pripada vremenu uprave hercega Stjepana ili, vjerojatnije, Vlatka Kosače u Primorju ili Krajini. ${ }^{113}$ Po svemu sudeći, ona nije jedini arhitekton-

"Crtice o Kačićima u Makarskom primorju u XV veku (ćirilica)", u: Istorijski časopis, LV., Istorijski institut SANU, Beograd 2007., str. 127, bilj. 41.

110 Do utvrđivanja sa sigurnošću dolazi tek stoljeće kasnije, kada je Makarska već dugo pod osmanskom vlašću: MARInko Tomasović, "Zidine grada i položaj muslimanskog groblja u osmanskoj Makarskoj 16.-17. stoljeća", u: $M a-$ karsko primorje, 10, Gradski muzej Makarska, Makarska, 2012., str. 71-79, s reperkusijama o fortificiranju još od kasnoantičkog razdoblja.

111 Faze gradine na Sv. Petru, od prapovijesti do osmansko-venecijanskog razdoblja, pregledno vidi: MARinko Tomasović, "Lokalitet: Makarska - Sv. Petar. Naselje: Makarska; Grad/općina: Makarska; Sustavno iskopavanje", u: Hrvatski arheološki godišnjak, Ministarstvo kulture Republike Hrvatske, 8/2011., Zagreb, 2012., str. 620-625; M. TomAsović, "Lokalitet: Makarska - Sv. Petar...", u: Hrvatski arheološki godišnjak, 9/2012., Zagreb, 2013. (u tisku); M. TomAsović, "Lokalitet: Makarska - Sv. Petar...", u: Hrvatski arheološki godišnjak, 10/2014., Zagreb, 2015. (u tisku); M. Tomasović, "Lokalitet: Makarska - Sv. Petar...", u: Hrvatski arheološki godišnjak, 11/2015., Zagreb 2016. (u tisku).

112 KARLO JuRIŠIć, "Priroda i kulturna baština na području Makarskog primorja", u: Acta Biokovica, I., Institut planina i more, Makarska 1981., str. 295; I. Alduk - M. Tomasović, nav. dj., str. 169-170.

113 Pak, donekle je otvoreno značenje naziva Rta Erceg (inače, u Makarskom primorju i zabiokovlju učestalog prezimena) koji s južne strane poluotoka Osejava zatvara makarsku luku. Pojas ima hidroarheološki značaj, ali je nalazima nedostatan za jasnije predočavanje kasnosrednjovjekovne faze: M. Tomasović, "Neka pitanja uz sagledavanje podmorskih nalaza u Makarskoj", u: LukA BeKić (prir.), Jurišićev zbornik, Zbornik radova u znak sjećanja na Marija Jurišića, Zagreb, 2009., str. 409. 
ski ostatak srednjovjekovne fortifikacije u Primorju, obalnom pojasu između Cetine i Neretve, koji bi se i nazivom očitovao kroz pripadnost razdoblju Kosača. Kao tadašnja utvrda pretpostavljen je Jugovića grad na podjednakom nepristupačnom Viteru u Zaostrogu. ${ }^{114}$ Njegova gradnja predstavlja kvadratičnu kulu s korištenjem žbuke kao veziva, vel. 7 x $7 \mathrm{~m}$ i s produžetkom zida ka jugu. Elaboriranjem povijesnoga konteksta, izvora i predaje, utvrda je promotrena kao gradnja Vukmana Jugovića, vjernog podanika hercega Stjepana, ali i nasljednica promatračnice Porfirogenetova kastruma Ostrog u podnožju. ${ }^{115}$ Ranosrednjovjekovni kastrumima, predočivim u izvoru, topografija još nije usuglašena u povijesnim znanostima, a izostaju im i pouzdani dokazi kontinuiteta u kasnom srednjem vijeku. ${ }^{116}$

Gotovo sigurno, utvrda u 15. st. nalazila se na Gradini u Drveniku, u gornjem Makarskom primorju, selu spomenutom još 1276., a kao posjed i $1417 .{ }^{117}$ Međutim, bez istraživanja nije lako reći u kakvom je opsegu ukorporirana u nesumnjive nadogradnje iz osmansko-venecijanskog razdoblja. Spomenički kontekst najužeg, ali i njezina tek nešto šireg pojasa, sa sigurnošću dokazuje duži kontinuitet drveničke utvrde, najvjerojatnije još od 13.-14. st. ${ }^{118}$

114 Karlo Jurišić, "Despotov Zaostrog kroz povijest (ulomci iz prošlosti)", u: ŽARKo Despot (prir.), Život i djelo Ivana Despota, Radovi sa znanstvenog savjetovanja, Makarska - Zaostrog, 18.-20. prosinca 1986., Makarski zbornik, 2, Makarska, 1989., str. 291-296.

115 M. Tomasović, "Arheološke sugestije za ubikaciju gradova iz 36. poglavlja Porfirogenetova De administrando imperio", str. 294-297.

116 Ubikacija im se predočava i pozivanjem na strukturiranje kasnoantičkih naselja u podnožju: M. Tomasović, "Arheološke sugestije za ubikaciju gradova iz 36. poglavlja Porfirogenetova De administrando imperio", str. 293-313.

117 K. JuRIšıć, "Nazivi naselja Makarskog primorja (Prvi spomen i značenje)", str. 102.

118 Na zapadnoj padini Gradine u Drveniku, zasnovane u ilirsko vrijeme, vidljivi su temelji jednobrodne crkve s polukružnom apsidom na istoku. Toponomastički se, $\mathrm{Na} \mathrm{Kuzmi,} \mathrm{dokazuje} \mathrm{njezin} \mathrm{titular,} \mathrm{dok} \mathrm{tipologija} \mathrm{upućuje} \mathrm{na}$ romaničku gradnju 12.-14. st., vrijeme spomena Drvenika sredinom 13. st. Crkva sv. Kuzme nesumnjivo je pripadala jezgri uz tvrđavu, dok je sjevernija Sv. Jurja s grobljem datirana u 15. st.: M. Tomasović, "Toponomastika i hagiotoponomastika kroz arheološke indicije za obalni pojas između donjeg toka Cetine i Neretve", str. 122. Neuvjerljiva je interpretacija drveničke utvrde kod: Anita Gamulin, "Utvrde Gornjeg primorja", u: ŽEljko Radelić (prir.), Hrvatski rasadnik - Zbornik članaka znanstvenog skupa Gornje makarsko primorje, Gradac - Zaostrog, 26. 9.-27. 9., 1996., Zagreb, 1999., str. 


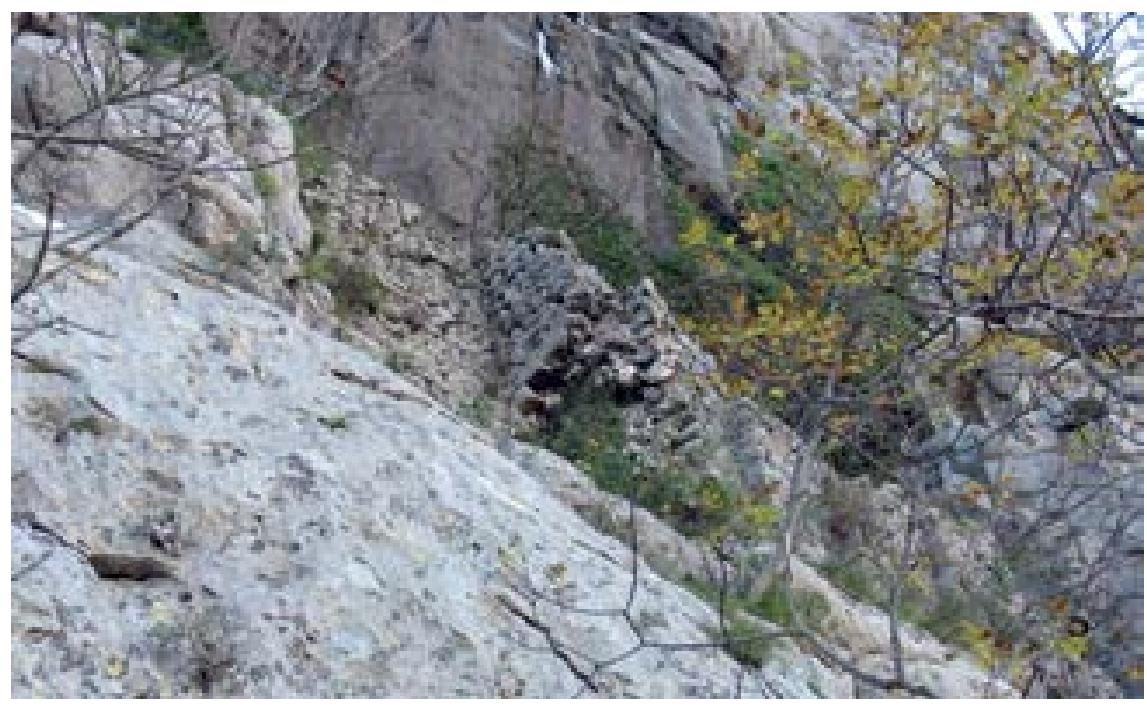

Sl. 41. Kasnoantička eremitaža iznad Cetine kod Omiša

(foto: Marinko Tomasović)

\section{Neutemeljene predaje o gradnjama i znamenjima Stjepana Vukčića Kosače}

Kod Omiša, samo $2 \mathrm{~km}$ od ušća Cetine, uz teže pristupačne litice Dinare iznad ceste s lijeve strane rijeke, sačuvani su ostatci ožbukane gradnje s nadsvođenom cisternom i njezinim vanjskim pravokutnim kontraforima (slika 41). ${ }^{119}$ Postavljena je uz rub zaravnjenoga grebena

79-81, gdje se netočno tvrdi kako je spomenuta kao posjed humskih knezova Vlatkovića, pri čemu se auktorica poziva na S. Zlatovića, koji ne navodi izvor. Netočna je i tvrdnja o prvom spomenu Drvenika tek 1494., a razvidna i nesigurnost po pitanju same utvrde u 15. st., koja se pretpostavlja, a odmah potom uzima kao sigurna. Osloncem na uistinu benevolentno Zlatovićevo pisanje kako Osmanlije drveničku utvrdu nisu koristili iz straha od Uskoka i Mlečana (sic!), već samo stanovništvo za zbijeg, proisteklo je da se na tvrđavi i nije graditeljski interveniralo tijekom 16.-17. st. (ili su to, barem tako proizlazi, samoinicijativno poduzimali Drveničani, u što je uistinu teško povjerovati). Upadljivo je kako se, inače u većem odlomku teksta o utvrdi, ova uopće i ne pokušava datirati, iako se govori o nekim moguće starijim dijelovima.

119 Marinko Tomasović, "Ranokršćanska eremitaža nadomak Omiša", u: Omiški ljetopis, Župa sv. Mihovila arkanđela u Omišu, VI./6, Omiš, 2011., str. 57-71; MARinko Tomasović, "Ranokršćanska eremitaža nedaleko ušća Cetine i pećina iznad Zelenog vira u Svinišćima", u: Obavijesti Hrvatskog arheološkog društva, XLIII./1-2, Zagreb, 2011., str. 21-36. 
dužine $37 \mathrm{~m}$ i širine $7 \mathrm{~m}$, odakle se gledaju Cetina i Poljica. Podsjetilo se kako je za gradnju davno rečeno kako predstavlja utvrdu Herceg Stjepana ${ }^{120}$ iako se s nje nisu nadzirali bitniji putni pravci, riječni ni kopneni. Uz to, položaj bi za utvrdu bio i nelogično odabran, uvučen i posve izoliran, bez mogućnosti komuniciranja s drugim točkama. Gradnja je stoga determinirana, i u pogledu ulomaka amfora, kao eremitaža iz kasne antike, pustinjačko obitavalište u surovom i negostoljubivom krajoliku idealnim za meditaciju i molitvu, a koje nije zaživjelo nakon 5. ili 6. st. Ukoliko je i poslužila u ugarsko-hrvatskom i osmansko-venecijanskom razdoblju, uloga mu je bila beznačajna, možda u kakvom usputnijem događanju.

Pripisivanje kasnoantičke gradnje Stjepanu Vukčiću Kosači dokazuje naknadno, preaktivno sagledavanje povijesne epizode njegove vlasti nakon osmomjesečnoga opsjedanja i teškog razaranja Omiša (1440.1444.), ${ }^{121}$ ali i ponovnoga posjedovanja grada 1448 . i $1454 .{ }^{122}$ Sjećanje na hercega Stjepana ponajbolje se očituje u tumačenju, još sredinom 19. st., grba na spoju pročelja renesansne crkve Svetoga Duha i kasnijeg tornja gradskog sata u Omišu kao njegovog znamenja, iako pripada mletačkoj obitelji Memmo s početka 17. st. (slika 42). ${ }^{123} \mathrm{Mi}-$ šljenje Mijata Sabljara kako grb pripada bosanskom velikašu svojevrsna je lokalna memorija u povijesnom sagledavanju. Podudarna je mletačkim i austrijskim izvorima kada neizostavno vezuju događaje u Omišu upravo za Stjepana Vukčića Kosaču u razdobljima koji su prethodili njihovoj upravi. ${ }^{124}$ Prirodu pogrješke o tumačenju kasnijeg grba kao Kosačina odaje Sabljareva zabilješka kako je na pročelje crkve prenijet "iz jedne gradine više Omiša". ${ }^{125}$ Poznata je tradicija

120 Jakov Tomasović, Omiš, Omiš, 1932., str. 44. Predaja o hercegu Stipanu kao graditelju utvrde inače je ukorijenjena u uzvodnim Kučićima, zavičaju pisca.

121 Mladen Ančić, "Srednjovjekovni Omiš", u: Žarko Domljan (prir.), Omiš i Poljica, Zagreb, 2006., str. 58.

122 M. Vego, Naselja bosanske srednjovjekovne države, str. 85.

123 Marinko Tomasović, "Grb s pročelja crkve sv. Duha kao dokaz omiške memorije sredinom 19. stoljeća", u: Omiški ljetopis, Župa sv. Mihovila arkanđela u Omišu, VI./6, Omiš, 2011., str. 155-160.

124 Vanja Kovačıć, "Fortifikacije grada Omiša", u: Radovi Instituta za povijest umjetnosti, 16, Zagreb, 1992., str. 38, bilj. 5.

125 M. Tomasović, "Grb s pročelja crkve sv. Duha kao dokaz omiške memorije sredinom 19. stoljeća", str. 155-160. 


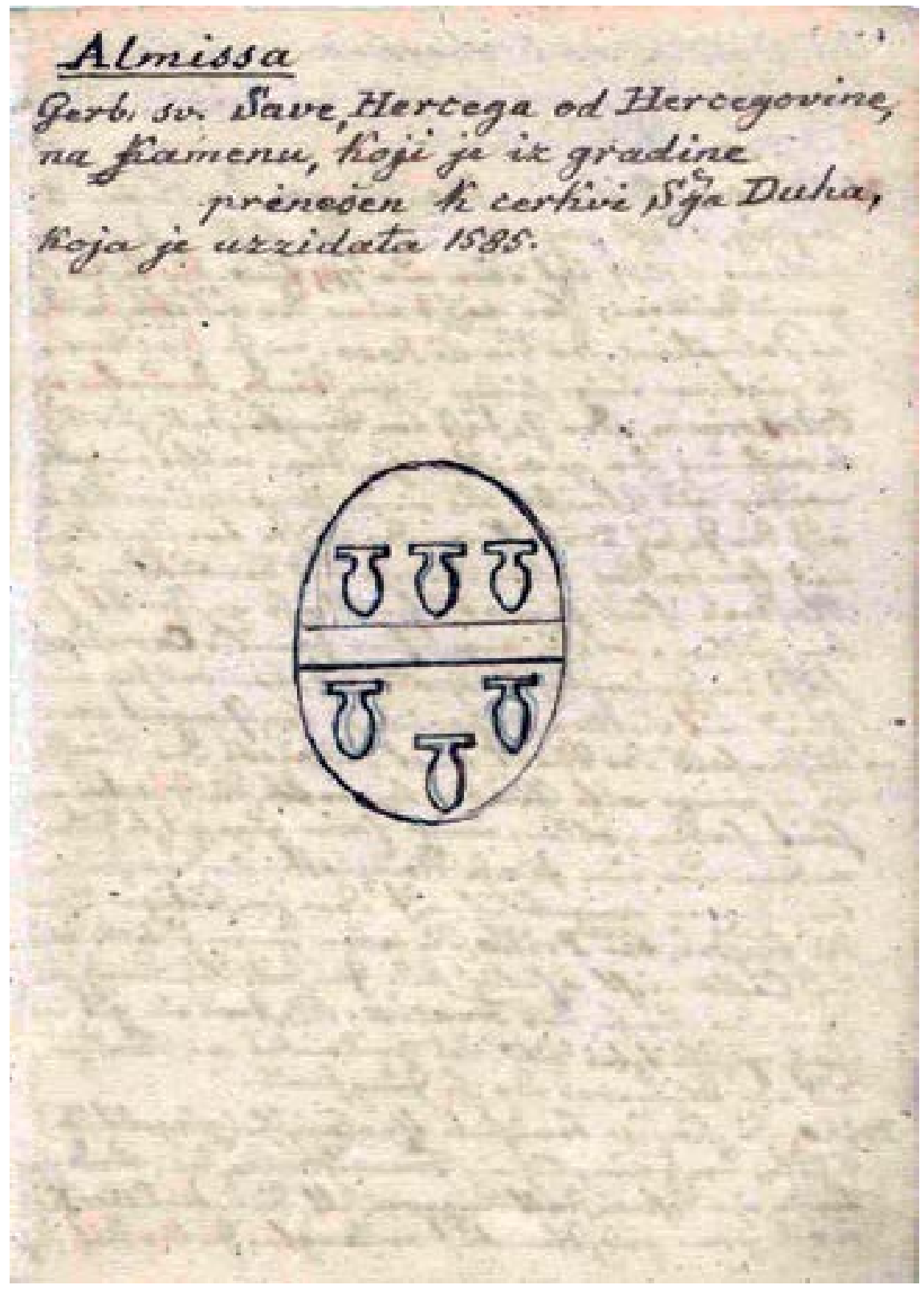

Sl. 42. Stranica terenske bilježnice Mijata Sabljara na kojoj pripisuje mletački grb hercegu Stjepanu Kosači (bilj. 20; Arhiv Ministarstva kulture Republike Hrvatske) 
kako je kaštel sa sačuvanom romaničkom kulom Mirabellom (Peovica) iz 13. st. sadržavao i rezidenciju hercega Stjepana. ${ }^{126}$ Nema dvojbi kako je Sabljar pomišljao na ovaj kaštel, možda i na uzdignutiju utvrdu Starigrad, pri čemu nije sagledao raskorak između Kosačina vremena i početka 17. st. kada su obje utvrde pregrađivane. ${ }^{127}$ Stoga je navod o mletačkom grbu kao tobožnjem znamenu hercega Stjepana potvrda dugotrajne i žive tradicije o značenju bosanskoga velikaša u povijesnom tijeku utvrđenoga grada na ušću Cetine, zadržane sve do sredine 19. st., ${ }^{128}$ a ukorijenjene u omiškom zaleđu i dugo nakon toga.

Inače, predaje o pripadnosti gradnjama pojedinim srednjovjekovnim vladarima nisu česte za priobalni pojas. Osim Hercegove kule u Brelima i Ercegove gradine iznad Makarske, u Primorju je takva predaja istaknuta u još jednom slučaju, iako donekle ima folkloristički karakter. Predaja se odnosi na uzvisinu Matijaševicu u živogoškom Blatu, inače ilirsku gradinu bez kontinuiteta $u$ antičkom i kasnijim razdobljima. ${ }^{129}$ Položaj je navodno dobio ime po kralju Matijašu i njegovoj vojci koja je držala gradinu. ${ }^{130} \mathrm{Na}$ njoj su, prema priči, nađene i "grčke vaze", što je zanimljiva simbioza oznake drevnosti lokaliteta (koji, užom arheološkom determinacijom, zamire upravo uoči grčko-helenističkog razdoblja!) s "preciziranjem" funkcije uzvisine kao utvrde upravo, i isključivo, navodom posade jednoga kralja. Vezivanje gradine za hrvatsko-ugarskoga kralja Matiju Korvina (1458.-1490.) tek je manjim dijelom uklopljivo u vremenski kontekst

126 V. Kovačić, "Fortifikacije grada Omiša", str. 29.

127 Obnove gradskih fortifikacija u 16.-17. st. morale su zahvatiti i Peovicu kao dominantnu gradsku obrambenu točku: V. KovAčıć, "Fortifikacije grada Omiša", str. 31, 34.

128 Zanimljivo je da Mijat Sabljar nije mario za izgled barokne punoće okvira grba, niti ga je crtao, očito u namjeri da mu poda izgled kakvim se je i mogla prikladnije dočaravati ideja njegove pripadnosti hercegu Stjepanu Kosači. Izvježbanim okom u iskustvu bilježenja obalne kulturne topografije Sabljar je ostavio traga i u kratkotrajnom omiškom boravku 1854. ili 1854.: MARINko Tomasović, "Bilješke Mijata Sabljara (1790.-1865.) o Poljicima i Omišu", u: Omiški ljetopis, Župa sv. Mihovila arkanđela u Omišu, VII./7, Omiš, 2014., str. 106-124.

129 Marinko Tomasović, "Matijaševica u Blato/Živogošću - željeznodobna gradina u gornjem Makarskom primorju", u: Obavijesti Hrvatskog arheološkog društva, XXXVII./1, Zagreb, 2005., str. 49-57.

130 Priču sam zabilježio 15. III. 2006. kazivanjem pučkog pjesnika Vice Jukića, prilikom jednog od arheoloških rekognosciranja Živogošća. 
spomena Živogošća u srednjem vijeku, koje se nakon 13. st. ponovo spominje u izvorima i krajem 14. st. ${ }^{131}$ Primarno je sagledavanje kako Matija Korvin simbolizira posljednji odbljesak moći jednoga ugarsko-hrvatskog kralja u provedbi, makar kratkotrajnoj, uspjele pomorske politike na donjoneretvanskom priobalju, u čemu je Primorje bilo od posebne važnosti. ${ }^{132}$ Pak, činjenica je kako se susjedne Igrane navode u izvorima 1466. upravo od strane Stjepana Vukčića Kosače, koji je ovo selo poklonio mletačkom časniku, ${ }^{133}$ da bi ga 1480 . kao svoj posjed u darovnici priznao kralj Matija Korvin. ${ }^{134}$ Očitovanje takve lokalne historiografske simbioze dvaju vladara u stvarnosti je posvjedočeno i njihovim ulogama na općem, kudikamo značajnijem političkom planu. Herceg Stjepan sa sinom Vladimirom, netom nakon njihove pomirbe, krajem 1463. postaje saveznik kralja Matije Korvina u uspjelim vojnim akcijama povrata Bosne osvojene od Osmanlija. ${ }^{135}$ Pak, o natpisu iz susjednih Drašnica sa spomenom

131 Živogošće se kao selo spominje sredinom 13. st. u dokumentu srpskog kralja Uroša I., kao posjed novoosnovane humske pravoslavne episkopije u Stonu nakon protjerivanja katoličkog biskupa: Minailo Dinić, "Tri povelje iz ispisa Ivana Lucića" (ćirilica), Zbornik Filozofskog fakulteta u Beogradu, III., Beograd, 1955., str. 69-94; 80; K. Jurišıć, "Nazivi naselja Makarskog primorja...", str. 100, 111. Živogošće (Xiuogosc) u Krajini spominje se i 1391.: MLADEN ANČIĆ, "Ser Ciprijan Zaninov. Rod i karijera jednog splitskog patricija druge polovice XIV. st.", u: Radovi Zavoda za povijesne znanosti HAZU u Zadru, 39, Zadar, 1997., str. 50, bilj. 55.

132 A. Paponja, "Prostor donje Neretve u vojno-obrambenoj strategiji kralja Matijaša Korvina (1458-1490)", str. 50; Ante PAPONJA, "Neki aspekti osmanske strategije prodora na području zapadno od Neretve", Hercegovina, 23, Godišnjak za kulturno i povijesno naslijeđe, Narodna knjižnica, Mostar, 2009., str. 111.

133 K. Jurišıć, "Nazivi naselja Makarskog primorja (Prvi spomen i značenje)", str. 99. Pri nizanju nekih imena posjeda iz Uroševe povelje iz 13. st. (uza Živogoće i Bivolje Brdo kod Počitelja) navode se i Igrane: M. ANčić, Na rubu Zapada. Tri stoljeća srednjovjekovne Bosne, str. 157.

134 I. Božić, nav. dj., str. 124, bilj. 53. Na ovo podsjeća: A. PAPONJA, "Prostor donje Neretve u vojno-obrambenoj strategiji kralja Matijaša Korvina (14581490)", str. 68, bilj. 115, iako s netočnom paginacijom kod pozivanja na Božićev rad. S pravom konstatira važnost komunikacijskog planinskog prijevoja u Igranima, nesumnjivo preko Strožca na granici s Drašnicama.

135 A. Paponja, "Prostor donje Neretve u vojno-obrambenoj strategiji kralja Matijaša Korvina (1458-1490)", str. 51-52; Đ. Tošıć, "Bosanska vlastela u oslobađanju Jajca od Turaka 1463.", u: ANTE BIRIN (prir.), Stjepan Tomašević (1461.-1463.) - slom srednjovjekovnoga Bosanskog Kraljevstva, Zbornik rado- 
hercega Stjepana Vukčića Kosače u godini njegove smrti, 1466., već je bilo govora.

Nesumnjivo, buduća arheološka istraživanja na Koledniku uz Stojno polje u Drašnicama rasvijetlit će graditeljski niz crkava na tom prostoru, među kojima je i starija crkva sv. Stjepana. Onu koju je ruševnu 1466. zatekao herceg Stjepan Vukčić Kosača, možda korjenito obnovio, ili kao novu podigao u gotičkom stilu u blizini kasnoantičke i ranosrednjovjekovne prethodnice.

va sa Znanstvenog skupa održanog 11. i 12. studenoga 2011. u Jajcu, Hrvatski institut za povijest - Katolički bogoslovni fakultet u Sarajevu, Sarajevo, 2013., str. 99-108. 


\section{Gothic Art in Primorje, Gorska Zupa and Radobilja in the Time of the Herzog Stjepan Vukcic Kosaca - between Reality and Folk Tradition}

\section{Summary}

Gothic art in Primorje (Krajina), Gorska Zupa and Radobilja was emphasized during the rule of the Herzog Stjepan Vukcic Kosaca over the territories between Cetina and Neretva, around 1440-1416. Churches with rectangular shrine, mostly with partitions, mentioned in the Ottoman 16 th- $17^{\text {th }} \mathrm{c}$. prove that they were built in the $15^{\text {th }}$ century. The buildings were erected according to the model of the Franciscan churches of Our Lady in Makarska and Zaostrog from the $15^{\text {th }}$ century. The Makarska church even after the destruction in the $16^{\text {th }}$ and $17^{\text {th }}$ c., preserved the aisle with a rectangular shrine. Such is St. Nicholas' church in Gornja Brela and reconstructed St. Cosmas and Damian church in Rogoznica, mentioned in 1461. In the church of St. Luke in Kucici the foundations of an earlier church with a rectangular apse were discovered. During Stjepan Kosaca's rule in the Omis hinterland there were built other churches, mentioned in the list from 1625. In Gorska Zupa worth mentioning is St. Peter in Dusina from 1585. In Lower Neretva area, St. Stjepan in Slivno Ravno has preserved only a sanctuary, while the foundations of St. Nichola's in Borovci prove its Gothic construction. The inscription with the name of the Herzog Stjepan from 1466 indicates that he constructed the church in Drasnice to honor the saint of the same name. The top door reliefs with relief crosses in Tucepi and Borovci belong to the churches from the $15^{\text {th }}$ century, as well as the aspersorium of St. Luke's church in Kucici. At the beginning of the $15^{\text {th }}$ century, St. Juraj in Tucepi and St. Ivan in Podaca were painted with dedicated crosses, inside squares and decorated circles. Their tombstones and plaques are also worth mentioning. The tombstones were related to Vlachs, and plaques with heraldic features to the local ethnic groups. The number of Vlachs was significant at the time of the Herzog Stjepan, when most of the tombstones were made. In the Omis fortress of Pec, according to tradition, the Herzog had a residence, but he also owned Starigrad and Visuc up the river. In Radobilja he intended to raise the bridge across the river and a fortress, which the Venetians 
in 1457 were seeking to destruct. He also owned Vrgorac in Gorska Zupa, whose wall had a Gothic crown and towers at the bottom. Additionally, there is Vratar on the right side of the Neretva, and Brstanik near Opuzen, important in the war with Dubrovnik from 1451 to 1454. The Herzog's Tower was preserved in Gornja Brela. It is an indication of the rule of Kosacas, as well as the Erceg's hill above Makarska, erected as a part of town fortification plan. Ermitage along the Cetina river from $5^{\text {th }}-6^{\text {th }} \mathrm{c}$. is linked to the Herzog, as a remembrance of his rule (1440-1444) in Omis, as well as the interpretation of the Venetian coat of arms from the $17^{\text {th }}$ century as his. The tradition was indirectly linked to the Herzog Stjepan in the name of the Illyrian fortress Matijasevica in Zivogosce, relating it to the Croat-Hungarian king Matija Korvin. Both rulers were allies in 1463 in the battles to return Bosnia from the Ottomans.

Keywords: Gothic architecture of churches; liturgical vessels; relief crosses; painted crosses; tombstones (stecaks); grave plaques; triangular gables; cross vaults; fortresses; Herzog's tower; Erceg's hills. 